UNIVERSIDADE DE SÃO PAULO

FACULDADE DE ECONOMIA, ADMINISTRAÇÃO E CONTABILIDADE DEPARTAMENTO DE CONTABILIDADE E ATUÁRIA PROGRAMA DE PÓS-GRADUAÇÃO EM CONTABILIDADE E CONTROLADORIA

RELAÇÃO ENTRE ESTÁGIOS DE MATURIDADE DA GESTÃo LOGÍSTICA, CICLO DE VIDA ORGANIZACIONAL E UTILIZAÇÃO DE ARTEFATOS DE CONTROLE GERENCIAL

Rodrigo Paiva Souza

Orientador: Prof. Dr. Reinaldo Guerreiro

SÃO PAULO 
Prof. Dr. João Grandino Rodas

Reitor da Universidade de São Paulo

Prof. Dr. Reinaldo Guerreio

Diretor da Faculdade de Economia, Administração e Contabilidade.

Prof. Dr. Edgard Bruno Cornachione Jr Chefe do Departamento de Contabilidade e Atuaria

Prof. Dr. Luis Eduardo Afonso

Coordenador do Programa de Pós-Graduação em Ciências Contábeis 


\title{
RELAÇÃO ENTRE ESTÁGIOS DE MATURIDADE DA GESTÃ̃ LOGÍSTICA, CICLO DE VIDA ORGANIZACIONAL E UTILIZAÇÃO DE ARTEFATOS DE CONTROLE GERENCIAL
}

\begin{abstract}
Dissertação apresentada ao Departamento de Contabilidade e Atuária da Faculdade de Economia, Administração e Contabilidade da Universidade de São Paulo como requisito para obtenção do título de Mestre em Ciências Contábeis.
\end{abstract}

Orientador: Prof. Dr. Reinaldo Guerreiro

\section{Versão Corrigida}

(Versão original disponível na Unidade que aloja o Programa)

\section{SÃO PAULO}




\section{Souza, Rodrigo Paiva}

Relação entre estágios de maturidade da gestão logística, ciclo de vida organizacional e utilização de artefatos de controle gerencial / Rodrigo Paiva Souza. -- São Paulo, 2011.

$126 \mathrm{p}$.

Dissertação (Mestrado) - Universidade de São Paulo, 2011.

Orientador: Reinaldo Guerreiro.

1. Logística 2. Cadeia de suprimentos 3. Ciclo de vida I. Universidade de São Paulo. Faculdade de Economia, Administração e Contabilidade II. Título. 
Aos meus pais e irmãos, exemplo e inspiração. 
Agradeço a Deus porque esteve sempre ao meu lado quando eu precisei e permitiu que eu alcançasse essa vitória, algo que parecia tão improvável dado os cenários que se apresentaram em determinados momentos da minha vida.

Tudo o que conquistar na vida eu dedico à família maravilhosa que tenho, por isso, agradeço aos meus pais e irmãos. Infelizmente meu querido pai, Damião, não está mais fisicamente presente, mas a sua trajetória de vida ensina muitas coisas e sempre será uma fonte de inspiração para mim. Para minha mãe, Teresinha, não existem palavras que possam expressar a minha gratidão, apenas posso ressaltar que sua fé salvou a minha vida no passado e que seu amor e dedicação me faz muito feliz no presente. Aos meus irmãos, Mateus e Rafael, que são para mim exemplos de coragem, honestidade e humildade, agradeço enormemente pelo companheirismo, amizade, união e principalmente pela confiança que sempre depositaram em mim, espero nunca decepcioná-los. Agradeço também às minhas cunhadas Eliana e Carolina pelo carinho e respeito que têm com os meus irmãos, comigo e minha mãe e ao meu sobrinho Pedro Henrique (Pedrinho), por trazer alegria e mais união ainda para essa família.

Também quero agradecer às pessoas que fizeram parte da minha trajetória de vida até esse momento e que de alguma forma contribuíram para o meu aprendizado: Paiva, Nielsa, Lúcia (enfermeira), Iracema (madrinha), Mário (padrinho), Edna, Ana Paula, Dauri, Aldivani, Simone, Marinalva, Jair, Davi, Glauber, Carla, Dennis, Júlia, Gregory, Joelma, Vinícius, Luizão, Henrique, Carol, Bruno, Francisco (Chico), Hélio e Renato. André (Val), Roosevelt, Anderson (São), Leonardo (Léo), Jé.

Agradeço à minha namorada Joyce, pelo seu amor e compreensão durante essa fase difícil do mestrado, que nos privou de estar juntos em muitos momentos. Também agradeço ao Sr. Marcos, D. Cida, Juliana e Felipe, que me receberam com tanto carinho. Aos meus colegas da pós-graduação, gostaria de deixar um agradecimento especial para àqueles que de alguma forma participaram e contribuíram com o meu projeto de pesquisa: Simone Costa; Renata Takamatsu; Valdomiro Junior; Tânia Nunes; Josué Braga; Marcelo Bicalho; Kelly Marques; Marcelo Barroso; Bruno Souza; entre outros. Finalmente, um agradecimento especial aos meus mestres, que foram importantes não só a para realização deste projeto, mas também para a minha educação e aprendizado como futuro educador: Reinaldo Guerreiro (orientador); Gerlando Lima; Sergio Bio; Marcos Oliveira; Welington Rocha; Márcio Borinelli; Fábio Frezatti; Ari Santos; Bruno Salotti; Luiz Corrar; Nelson Carvalho; Guilhermo Braunbeck e Gilberto Martins. 
"A mente que se abre a uma nova ideia, jamais voltará ao seu tamanho original." Albert Einstein 


\section{RESUMO}

Os processos logísticos impactam direta e indiretamente a vida das pessoas e são fundamentais para o sucesso das empresas. Modelos de maturidade oferecem uma maneira de traçar um caminho para melhorar processos ao ajudar a acrescentar competências e habilidades. O conceito de Maturidade da Gestão Logística propõe que os processos têm um ciclo de vida e que se torna mais maduro à medida que esses processos são explicitamente definidos, gerenciados, mensurados e controlados. Paralelamente ao desenvolvimento da gestão logística, as organizações crescem e expandem o seu portfólio de produtos ou serviços para atender mercados mais exigentes e, nesse processo, inevitavelmente enfrentam uma maior heterogeneidade de clientes e ambientes mais hostis. Nesse sentido, espera-se que as mudanças que ocorrem no ambiente organizacional sigam um padrão previsível que pode ser caracterizado por estágios de desenvolvimento, ou seja, estágios de Ciclo de Vida Organizacional. Esta dissertação investigou a relação entre os estágios dos modelos de maturidade da gestão logística e do ciclo de vida organizacional, bem como a relação entre a classificação das empresas nesses estágios e a quantidade média de artefatos de controle gerencial, tendo como hipóteses: (H1) a existência de relação entre os estágios desses dois modelos teóricos, e (H2) que, quanto mais desenvolvido o estágio, tanto no modelo de maturidade da gestão logística quanto no ciclo de vida organizacional, maior a quantidade média de artefatos utilizados. O método de coleta de dados utilizado foi o questionário e o público alvo constitui-se por profissionais que atuam na gestão logística ou em áreas relacionadas. A amostra final contemplou 213 empresas e o método estatístico para analisar as associações entre os estágios foi a análise de correspondência. Como principais achados destacam-se: confirmação de que existem associações não aleatórias entre os estágios de maturidade da gestão logística e do ciclo de vida organizacional, indicando que os gestores logísticos devem também considerar os construtos abordados nos dois modelos em projetos de desenvolvimento da maturidade da gestão logística. Também se constatou que os estágios mais desenvolvidos de maturidade de gestão logística possuem maior quantidade média de utilização de artefato de controle gerencial. Verificou-se ainda que o artefato Análise de custo logístico total foi o que apresentou maior média de utilização pelas empresas investigadas $(79,8 \%)$ e a Gestão de custos interorganizacioniais a menor (28,2\%). Dentre as recomendações para aprofundamento da pesquisa, sugere-se investigar se o estágio atual de maturidade de gestão logística das empresas está relacionado com o nível de complexidade da cadeia de suprimentos, aplicar técnicas confirmatórias para investigar a dinâmica das relações entre os estágios (qual o modelo com maior influência) e buscar entender os principais motivos da baixa utilização da Gestão de custos interorganizacioniais, uma vez que este é um caminho que pode tornar a cadeia de suprimentos mais eficiente e aumentar a sua lucratividade total. 


\begin{abstract}
The logistics processes impact directly and indirectly the lives of people and is vital to the success of companies. Maturity models offer a way to trace a path to improve processes while helps to add competencies and abilities to it. The concept of logistics management maturity proposes that the processes have a lifecycle and that becomes more mature as these processes are explicitly defined, managed, measured and controlled. Parallel to the development of logistics management, organizations grow and expand its portfolio of products or services to meet the most demanding markets and, in this process, inevitably faced greater heterogeneity of customers and most hostile environments. In this sense, it is expected that the changes that occur in the organizational environment follow a predictable pattern that can be characterized by stages of development, i.e. stages of organizational life cycle. This dissertation investigated the relationship between the stages of logistics management maturity model and organizational life cycle model, as well as the relationship between the classification of enterprises in these stages, and the average amount of artifacts of managerial control, having as hypotheses: (H1) the existence of relationship between stages of these two theoretical models, and (H2) in the more developed stage the average amount of artifacts used is greater. The data collection method was the questionnaire and the target population was professionals who work in the logistics management or related areas. The final sample involved 213 firms and the statistical method to analyze associations between stages was the correspondence analysis. The key findings include: confirmation that there are non-random associations between stages of logistics management maturity model and organizational life cycle model, indicating that the logistics managers must also consider the constructs discussed in two models in development projects of the maturity of logistics management. Also it was found that the more developed the stages of logistics management maturity is, higher is the average amount artifact of managerial control used by companies. It was also found that the artifact Total logistic cost analysis was more common in the companies investigated $(79.8 \%)$ and Interorganizacional cost management was uncommon (28.2\%). Among the recommendations for further research, it is suggested to investigate whether the current stage of logistics management maturity is related to the level of complexity of the supply chain, applying techniques to investigate the dynamics of relations between stages of the two models (which has largest influence) and seek to understand the main reasons for the low utilization of Interorganizacional cost management. Since this is a too which may make the supply chain more efficient and increase its total profitability.
\end{abstract}





\section{SUMÁRIO}

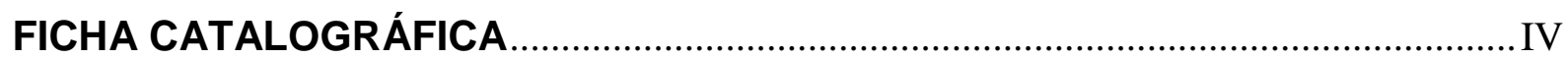

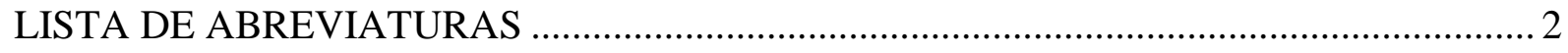

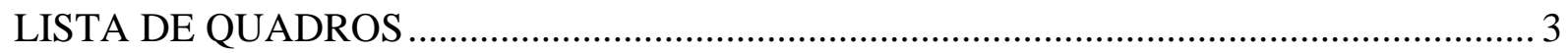

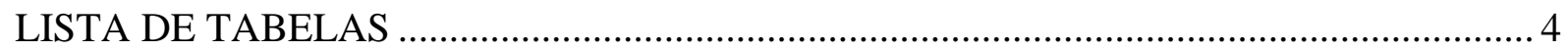

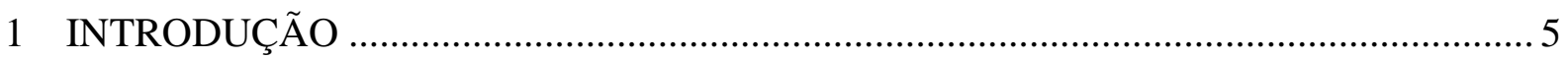

1.1 Caracterização da situação problema ................................................................................ 9

1.2 Questão de pesquisa........................................................................................................................................ 10

1.3 Objetivos da pesquisa ................................................................................................................................... 11

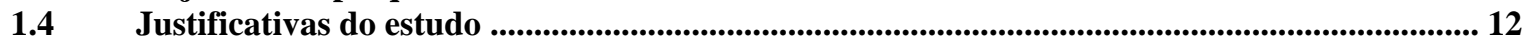

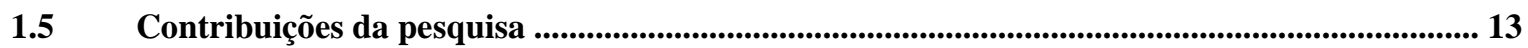

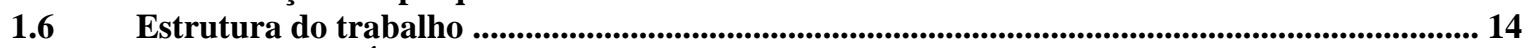

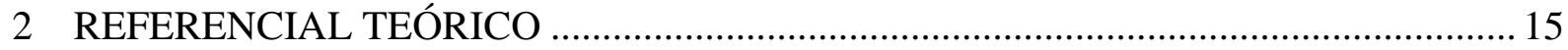

$2.1 \quad$ Logística................................................................................................................................................. 15

2.1.1 Integração logística................................................................................................................................. 16

2.1.2 Gestão da cadeia de suprimentos ....................................................................................... 18

$2.2 \quad$ Maturidade de processos.................................................................................................. 19

2.2.1 Maturidade de processos logísticos ............................................................................................................. 20

2.2.2 Modelo de maturidade da gestão logística de Oliveira (2009) .......................................................... 22

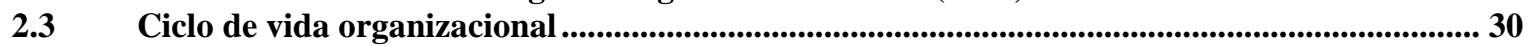

2.3.1 Relação entre estágios de CVO e Contabilidade Gerencial ......................................................... 34

2.4 Utilização de artefatos de controle gerencial na gestão logística ..................................................... 35

2.4.1 Avaliação de desempenho de fornecedores (Supplier Scorecard) .................................................. 35

2.4.2 Custeio baseado em atividade (ABC) e gestão baseada em atividade (ABM) ............................ 37

2.4.3 Plano de negócio integrado na gestão logística....................................................................................... 38

2.4.4 Gestão de custos interorganizacional .................................................................................................. 39

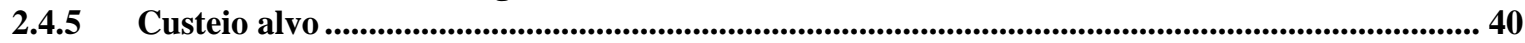

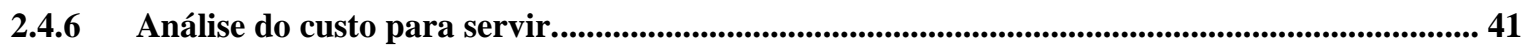

2.4.7 Análise do custo total na gestão logística ............................................................................................... 42

2.5 Formulação das hipóteses de pesquisa ........................................................................................................ 44

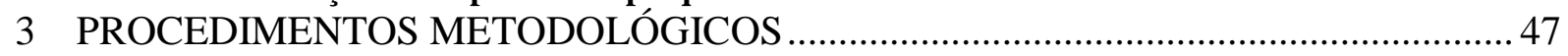

3.1 Instrumento de coleta - Estrutura do formulário ......................................................................... 48

3.1.1 Construção do formulário............................................................................................................................. 49

3.2 Público alvo, tamanho da amostra e recebimento das respostas ............................................... 51

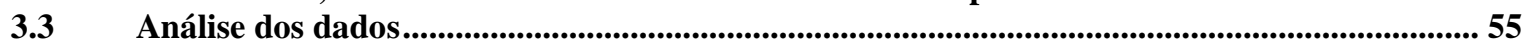

3.3.1 Classificação das empresas nos estágios de maturidade da gestão logística ................................. 55

3.3.2 Classificação das empresas nos estágios de ciclo de vida ..............................................................56

3.3.3 Determinação da média de artefatos utilizados por estágio ...............................................................59

3.3.4 Análise de correspondência (ANACOR) ...........................................................................59

3.4 Tratamentos e limitaç̃̃es da pesquisa...................................................................................................... 61

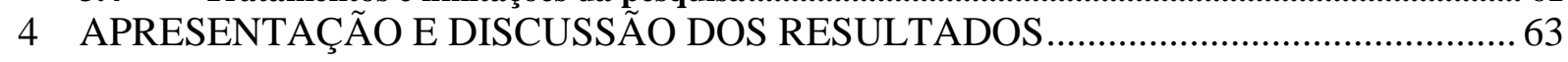

4.1 Análise do perfil dos participantes ............................................................................................................ 63

4.2 Classificação do estágio de maturidade da gestão logística (MGL) .........................................66

4.3 Classificação dos estágios de ciclo de vida organizacional (CVO) .................................................. 70

4.4 Relação entre estágios de MGL e CVO ................................................................................................. 74

4.5 Utilização de artefatos de controle gerencial........................................................................................... 84

5 CONSIDERAÇÕES FINAIS E RECOMENDAÇÕES ........................................... 91

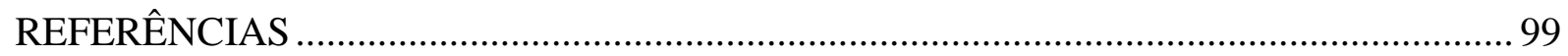

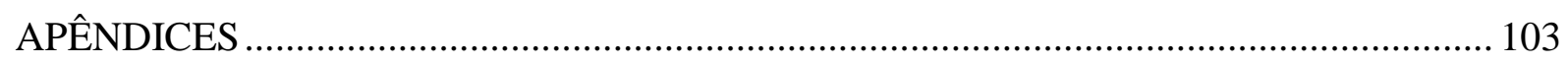

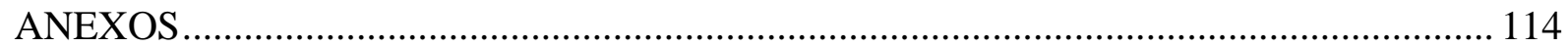




\section{LISTA DE ABREVIATURAS}

ABC: Activity Based Cost

ABM: Activity Based Management

ANACOR: Análise de Correspondência

APICS: The Association for Operations Managements

ASLOG: Associação Brasileira de Logística

CVO: Ciclo de Vida Organizacional

EUA: Estados Unidos da América

FEA: Faculdade de Economia, Administração e Contabilidade

GCS: Gestão da Cadeia de Suprimentos

GCI: Gestão de Custos Interorganizacional

IMA: Institute of Management Accountants

LOGICON: Centro de Pesquisa em Logística Integrada à Controladoria e Negócios

MGL: Maturidade da Gestão Logística

N/I: Não Identificado

OEM: Original Equipment Manufactures

PMG: The Performance Measurement Group

PNB: Produto Nacional Bruto

PNI: Plano de Negócio Integrado

SEBRAE: Serviço Brasileiro de Apoio às Micro e Pequenas Empresas

SEI: Software Engineering Institute

SCM: Supply Chain Management

SCMP: Supply Chain Management Professionals

SCMM3: Supply Chain Maturity Model 3

SCOR: Supply Chain Operation Reference model

SCPM3: Supply Chain Process Management Maturity Model

SPSS: Statistical Package for Social Science

UFMG: Universidade Federal de Minas Gerais

USP: Universidade de São Paulo 


\section{LISTA DE QUADROS}

Quadro 1 - Teste de Mann-Whitney para diferença de classificação de estágios de MGL ..... 50

Quadro 2 - Resultado do teste de homogeneidade das variâncias............................................ 54

Quadro 3 - Resultado teste de normalidade da distribuição................................................. 54

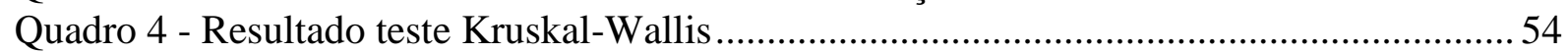

Quadro 5 - Teste de confiabilidade das respostas recebidas ................................................. 55

Quadro 6 - Pontos de transição para os estágios de maturidade do processo logístico............ 56

Quadro 7 - Relação entre afirmações e estágios do CVO .....................................................57

Quadro 8 - Relação entre o estágio de CVO e a idade da empresa.........................................58

Quadro 9 - Relação entre o estágio do CVO e o porte da empresa ..........................................59

Quadro 10 - Matriz de atribuição de escore por questão.......................................................... 67

Quadro 11 - Teste de média entre idade e estágios de MGL das empresas ..............................69

Quadro 12 - Teste de média entre porte de estágios de MGL das empresas.............................69

Quadro 13 - Teste de média entre CVO, Idade e Porte das empresas..................................... 74

Quadro 14 - Teste Qui-quadrado entre estágios de MGL e CVO.......................................... 76

Quadro 15 - Associação entre os estágios de desenvolvimento ............................................... 83

Quadro 16 - Teste de média entre o estágio de MGL da empresa e a utilização de artefatos.. 87

Quadro 17 - Teste de média entre estágio de CVO e utilização de artefatos ........................... 88

Quadro 18 - Teste de média entre porte da empresa e utilização de artefatos ..........................88

Quadro 19 - Teste de média entre idade da empresa e utilização de artefatos .......................... 89 


\section{LISTA DE TABELAS}

Tabela 1 - Distribuição de respondentes por grupo de origem ..................................................5

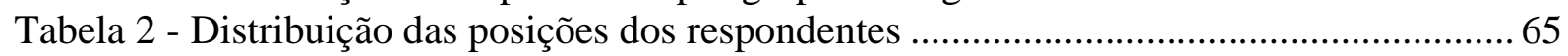

Tabela 3 - Quantidade de respondente por área de atuação ................................................. 65

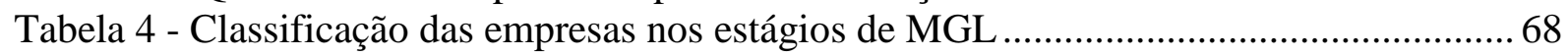

Tabela 5 - Relação entre idade das empresas e classificação da MGL ................................... 68

Tabela 6 - Relação entre porte das empresas e classificação da MGL ...................................69

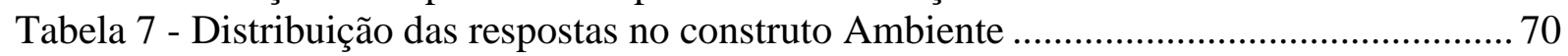

Tabela 8 - Distribuição das respostas no construto Modelo de Decisão.................................... 71

Tabela 9 - Distribuição das respostas no construto Estrutura Organizacional .......................... 71

Tabela 10 - Distribuição das respostas no construto Processamento de Informações .............. 72

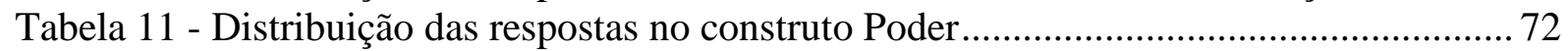

Tabela 12 - Matriz de respostas por construto e estágios de CVO ........................................... 73

Tabela 13 - Quantidade de empresa classificada em cada estágio do CVO.............................. 73

Tabela 14 - Relação entre idade da empresa e classificação no CVO....................................... 73

Tabela 15 - Relação entre porte da empresa e classificação no CVO ...................................... 74

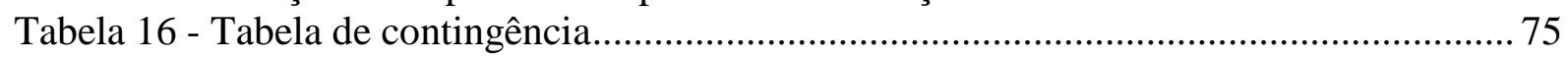

Tabela 17 - Cálculo da diferença entre valor observado e valor esperado.............................. 75

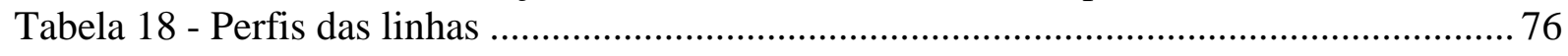

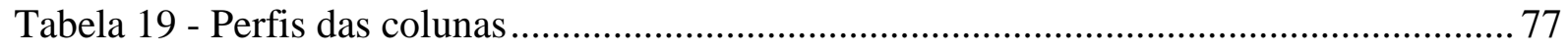

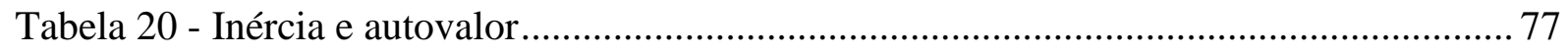

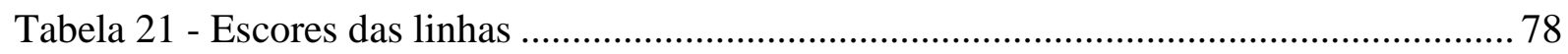

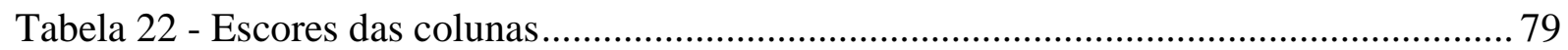

Tabela 23 - Quantidade de empresas que declaram utilizar cada artefato .............................. 85

Tabela 24 - Quantidade média de artefatos utilizada por estágio de MGL............................... 86

Tabela 25 - Quantidade média de artefatos utilizados por estágio de CVO ........................... 87

Tabela 26 - Quantidade média de artefatos por porte de empresa ........................................ 88

Tabela 27 - Quantidade média de artefatos por idade da empresa ........................................ 89 


\section{INTRODUÇÃO}

Quase todas as áreas da atividade humana são afetadas, direta e indiretamente, pelos processos logísticos (LAMBERT; STOCK, 1993, p. 3). A atividade logística é responsável pela movimentação e posicionamento geográfico dos inventários e envolve a combinação e o gerenciamento de ordens, o transporte, armazenamento e manipulação de inventários, bem como o desenvolvimento de embalagem (BOWERSOX et al, 2010, p. 4).

Sendo a atividade logística composta por uma combinação de atividades inter-relacionadas, definida como processo logístico, é preciso haver o gerenciamento estratégico desse processo. A gestão estratégica do processo logístico tem o objetivo de maximizar o resultado global da organização e oferecer o melhor serviço possível ao cliente (LAMBERT; STOCK, 1993, p. 6).

A palavra "logística" refere-se ao ambiente interno das empresas (BALLOU, 2006, p. 382). Quando a gestão do processo logístico extrapola os limites da organização e envolve outras empresas faz-se necessária a integração, colaboração e confiança entre as partes envolvidas. Portanto, para maximizar o resultado global das organizações envolvidas, a gestão estratégica do processo logístico deve contemplar a integração dos processos que ocorrerem tanto no ambiente interno quanto externo das organizações.

Segundo Chen et al (2009, p. 65) a integração interna é interfuncional e ocorre no ambiente interno da empresa, enquanto que a integração externa ocorre entre a empresa e seus parceiros externos (clientes, fornecedores, prestadores de serviços, etc.). O objetivo da logística integrada é desenhar a estrutura do processo logístico de forma que possa atender ao nível de serviço requerido pelo "cliente” desse processo, ao menor custo total possível (BIO, 2011).

A integração logística é uma maneira de sincronizar os processos das empresas que pertencem a uma cadeia de suprimentos para criar um processo contínuo. (BOWERSOX et al, 2010, p. 4). Para Chen et al (2009, p. 66) a gestão da cadeia de suprimentos é a integração de processos chave das empresas.

Dessa forma, a gestão da cadeia de suprimentos (GCS) pode ser entendida como a coordenação do processo logístico ao longo de toda a cadeia de abastecimento, apoiada na 
integração logística, na colaboração entre os parceiros dessa cadeia e no compartilhamento de recursos e informações. Portanto, a principal diferença entre logística e GCS é que a primeira ocorre no ambiente interno de uma organização enquanto que a segunda inclui o ambiente externo e implica em colaboração entre empresas (BALLOU, 2006, p. 381).

O desenvolvimento de relacionamentos tanto no ambiente interno quanto externo às empresas geram novas contingências, que provocam aumento no grau de complexidade dos processos logísticos. Dessa forma, as empresas precisam desenvolver novas habilidades e competências para gerenciar essas contingências. Na literatura, esses desenvolvimentos nos processos logísticos são tratados como estágios de maturidade (LOCKAMY; MCCORMACK, 2004; STEVENS, 1989; PMG, 2007; MCCORMACK et al, 2008; OLIVEIRA, 2009).

Modelos de maturidade têm sido desenvolvidos para mensurar a competência, capacidade, e o nível de sofisticação de um domínio específico da organização (OLIVEIRA, 2009, p. 33). O conceito de maturidade da gestão da cadeia de suprimentos propõe que os processos logísticos têm um ciclo de vida e se tornam mais maduros à medida que são explicitamente definidos, gerenciados, mensurados e controlados (LOCKAMY; MCCORMACK, 2004, p. 272).

Nesta dissertação, será utilizado o modelo de maturidade de gestão da cadeia de suprimentos desenvolvido na tese de Oliveira (2009) - Supply Chain Process Management Maturity Model (SCPM3) para mensurar o estágio de desenvolvimento da GCS das empresas. O modelo supracitado será doravante denominado modelo de Maturidade da Gestão Logística (MGL), contudo, cabe ressaltar que o termo, quando utilizado nessa dissertação, estará se referindo a maturidade da gestão da cadeia de suprimentos. Esta adaptação foi realizada porque o termo "gestão logística" apresentou-se mais familiar aos participantes envolvido na fase de pré-teste, porém, o capítulo 2 trás uma discussão sobre os conceitos de logística, logística integrada e gestão da cadeia de suprimentos.

Esse modelo é composto por cinco estágios assim denominados: (1) Fundação, (2) Estrutura, (3) Visão, (4) Integração e (5) Dinâmica. Para classificar os estágios de maturidade são analisadas características de 13 construtos (competências), que serão introduzidos no capítulo dois. A motivação para a escolha desse modelo encontra-se no fato de ele representar o estado da arte em termos de modelos de maturidade da gestão logística e de ter sido desenvolvido 
com auxílio de um grupo de pesquisadores de diversos países, conforme detalhado no Referencial Teórico.

McCormack et al (2008, p. 272) afirmam que níveis mais elevados de maturidade em qualquer processo resultam em:

- Melhor controle sobre os resultados;

- Estimativas mais precisas para os objetivos, custos e desempenho;

- Maior eficácia no atendimento dos objetivos definidos; e.

- Otimização da habilidade gerencial para propor metas para o desempenho.

Da mesma forma como ocorre no caso da gestão logística, a configuração de contingências na gestão organizacional também passa por transformações ao longo do tempo. Segundo Miller e Friesen (1984, p. 1161), “[...] uma quantidade recorrente de transações é esperada quando uma organização jovem, pequena e simples se torna velha, grande e complexa." ${ }^{\text {. }}$

As características internas de uma organização, bem como o contexto externo onde está inserida, sofrem constante influência de fatores contingenciais que afetam os sistemas de controle gerencial (MARQUES; SOUZA, 2010, p. 1). Essas contingências atingem as organizações em diferentes dimensões, provocando mudanças em suas prioridades (LESTER et al, 2003, p. 340), bem como na estratégia, no modelo de decisão e na estrutura organizacional (MILLER; FRIESEN, 1984, p. 1161).

Dessa forma as organizações possuem características diferentes conforme o seu estágio atual do ciclo de vida. Lester et al, (2003, p. 340) explicam que o estágio do ciclo de vida é uma interpretação coletiva do ambiente organizacional, baseado em percepções dos gestores.

Esta dissertação utiliza o modelo de Lester et al (2003) para mensurar o estágio atual de ciclo de vida organizacional (CVO) das empresas pesquisadas. No modelo proposto pelos autores, existem cinco dimensões, ou atributos, que devem ser identificados e analisados para determinar o estágio do ciclo de vida da organização: (a) ambiente organizacional, (b) modelo

\footnotetext{
1 “A typical number of transactions are expected to occur as young, small and simple organization become older, larger and more complex."
} 
de decisão, (c) estrutura organizacional, (d) processamento de informações, e (e) distribuição de poder.

O modelo é composto por cinco estágios, que são definidos como: (1) Existência, (2) Sobrevivência, (3) Sucesso, (4) Reativação, e (5) Declínio. As definições dos atributos e as características de cada estágio do modelo são exploradas no Referencial Teórico.

Estudos têm demonstrado a existência de relação entre estágios do CVO com:

- Eficácia Operacional (QUIN; CAMERON, 1983);

- Níveis de formalização de sistemas de controle gerencial (MOORES; YUEN, 2001);

- Estratégias competitivas, satisfação do cliente e desempenho (LESTER et al, 2003);

- Formalização do processo de planejamento (FREZATTI et al, 2009);

- Desenho do sistema de controle gerencial e desempenho (JUNQUEIRA, 2010).

Em um estudo realizado com empresas brasileiras Frezatti et al (2009) concluíram que há correlação entre os estágios do CVO e a utilização de artefatos de planejamento estratégico, orçamento e controle orçamentário. Os autores constataram que em determinados estágios do CVO havia maior utilização de artefatos de controle gerencial.

Dada a constatação dos autores, especulou-se se a quantidade utilizada artefatos de controle gerencial voltado à gestão logística tem relação com o estágio atual de MGL das empresas. Para testar essa hipótese, selecionaram-se sete artefatos de controle gerencial cuja eficácia na gestão logística foi comprovada em estudos anteriores (TRENT, 2010; WANG et al, 2010; BRAITHWAITE; SAMAKH, 1998; MUZUMDAR; VISWANATHAN, 2009; LAMBERT; BURDUROGLU, 2000).

Os artefatos selecionados foram: supplier scorecard; custeio baseado em atividades (ABC); plano de negócio integrado (PNI); gestão de custos interorganizacional (GCI); custeio alvo; análise de custo para servir; e análise de custo total. 


\subsection{Caracterização da situação problema}

Considerando a importância do papel da atividade logística para o sucesso das organizações e a comprovação empírica de que a MGL melhora o desempenho operacional e financeiro das empresas (LOCKAMY; MCCORMARK, 2004; ARYEE, 2008, MCCOMARK et al, 2008; OLIVEIRA, 2009) pode-se imaginar que toda a empresa deveria dedicar uma atenção especial à atividade logística ou mesmo implantar metas para desenvolver a MGL.

Uma inquietação inicial do pesquisador consiste em tentar entender o porquê de algumas empresas conseguirem atingir maiores níveis de maturidade na gestão logística enquanto outras, não. Na dissertação de Mendel (2009), constatou-se que as empresas brasileiras já assimilam bem os conceitos de logística integrada, porém, têm dificuldade em aplicar os conceitos de gestão da cadeia de suprimentos.

Sabe-se também que a MGL exige que as organizações possuam habilidades especiais de gestão como: técnicas colaborativas, compromissos, construção de relacionamento e de confiança (BALLOU, 2006, p. 386). O desafio reside em encontrar fatores que possam explicar a dificuldade em desenvolver a gestão da cadeia de suprimento.

A leitura de alguns trabalhos sobre o tema $\mathrm{CVO}$, que relacionam os estágios do ciclo de vida das empresas a determinados competências da gestão (DOWN, 1967; SCOTT, 1971; ADIZES, 1979; KIMBERLY, 1979; QUINN; CAMERON, 1983; MILLER; FRIESSEN, 1984; MOORES; YUEN, 2001; FREZATTI et al, 2009), trouxeram indícios de um possível caminho para responder a essa inquietação inicial.

Esta dissertação parte da premissa de que é preciso uma abordagem sistêmica para tratar de temas organizacionais, ou seja, para entender melhor as dificuldades em se alcançar níveis desejados de MGL, o escopo de análise dos gestores logísticos não deve se limitar apenas às características intrínsecas ao processo logístico, nem nas competências individuais dos responsáveis por esses processos, ou seja, os gestores devem incluir variáveis próprias do ciclo de vida organizacional, como o ambiente e a estrutura organizacional, o modelo de decisão, a distribuição do poder e a eficácia do sistema de informações gerenciais. 
Provavelmente, os gestores de logística também não terão êxito em seus projetos de MGL se estes não estiverem alinhados com os interesses da organização. Como os interesses e prioridades das organizações variam conforme o seu estágio atual de ciclo de vida é possível que exista uma relação entre os estágios de MGL com o estágio atual do CVO.

Outra inquietação diz respeito à eficácia dos artefatos de controle gerencial no apoio à gestão logística. Se tais artefatos são realmente eficazes, espera-se que as empresas que se encontram nos níveis mais desenvolvidos do modelo de MGL utilizem mais artefatos de controle gerencial. Portanto, é preciso testar também se existe uma relação entre a quantidade média de artefatos utilizados com o estágio atual de MGL das empresas.

\subsection{Questão de pesquisa}

Dados os conceitos iniciais expostos sobre modelo de MGL, o modelo de CVO e a utilização de artefatos de controle gerencial, bem como a contextualização da situação problema, o trabalho se propõe a responder a seguinte questão de pesquisa:

\section{Qual a relação existente entre os estágios de desenvolvimento do ciclo de vida organizacional (CVO), estágios de maturidade da gestão logística (MGL) e utilização de artefatos de controle gerencial?}

Para buscar resposta à questão proposta, primeiramente, os dois modelos teóricos (CVO e MGL) foram explorados de forma individual por meio de revisão bibliográfica, possibilitando a construção do instrumento de coleta de dados. Em seguida, foi realizada uma pesquisa empírica, por intermédio da aplicação de um questionário direcionado a profissionais que atuam na gestão de logística e da cadeia de suprimentos. Utilizaram-se ferramentas quantitativas para tratar os dados coletados e buscou-se na teoria subsídios para interpretação dos resultados encontrados. 


\subsection{Objetivos da pesquisa}

Sampieri et al (2006, p. 36) explicam que os objetivos da pesquisa têm a finalidade de mostrar o que se deseja com a investigação e devem ser expressos com clareza, pois são orientações do estudo. Os autores comentam ainda que depois de estabelecer o objetivo inicial da pesquisa é possível que surjam objetivos adicionais.

Os objetivos iniciais desta dissertação são: investigar qual a relação existente entre estágios de maturidade da gestão logística (MGL), os estágios do ciclo de vida organizacional (CVO) e qual o padrão de utilização de artefatos de controle gerencial pelas empresas nesses diferentes estágios de desenvolvimento.

Para atender aos objetivos iniciais desta pesquisa, aplicou-se um questionário a fim de coletar informações acerca das organizações, o que permitiu classificá-las quanto ao estágio atual de MGL e CVO e verificar a quantidade de artefatos de controle gerencial utilizados pela gestão. Em seguida, verificou-se a associação entre esses estágios através da análise de correspondência (ANACOR).

O questionário foi dividido em cinco partes. As duas primeiras partes do questionário foram compostas, respectivamente, por um termo de compromisso do pesquisador e algumas questões para identificar o perfil da empresa e do respondente. O questionário continha, ainda, três blocos de perguntas: o primeiro bloco com questões sobre maturidade da gestão logística, o segundo sobre o ciclo de vida organizacional e o terceiro sobre a utilização de artefatos de controle gerencial. Os dois primeiros blocos tiveram as questões extraídas de modelos teóricos enquanto que o terceiro teve as questões construídas a partir da revisão da literatura.

Para mensurar a MGL, utilizou-se o modelo de maturidade desenvolvido por Oliveira (2009) o qual consiste em mensurar o estágio de maturidade da gestão logística das empresas através da identificação e quantificação de determinadas competências (atributos) presentes nessa atividade. Essas competências da gestão logística foram quantificadas a partir de atribuições de escores dados pelos respondentes, em uma escala de cinco pontos, para 25 situações que lhes foram expostas, conforme Apêndice 4. 
Para mensurar o estágio atual do ciclo de vida organizacional utilizou-se o modelo teórico desenvolvido por Lester et al (2003). Esse instrumento visa classificar o estágio atual do ciclo de vida de uma organização, identificando características da configuração de cinco construtos: ambiente, modelo de decisão, estrutura organizacional, processamento de informações e estrutura de poder. Para cada um desses construtos foi formulada uma questão contendo de três a seis alternativas, sendo que o participante deveria escolher aquela que mais se adequasse ao contexto da sua organização.

Uma vez atendido a primeira parte do objetivo inicial da dissertação, investigou-se também a relação existente entre a utilização de artefatos de controle gerencial e o estagio atual de desenvolvimento, de acordo com os modelos teóricos de MGL e CVO.

Foram selecionados sete artefatos de controle gerencial com objetivo de investigar sua relação com os estágios dos modelos supracitados. Os artefatos são: supplier scorecard, custeio baseado em atividades (ABC), plano de negócio integrado, gestão de custos interorganizacional, custeio alvo, análise de custo para servir e análise de custo total. $\mathrm{O}$ critério de seleção desses artefatos foi por comprovação empírica, em trabalhos anteriores, de sua eficácia na gestão logística. O fato de o escopo desta dissertação conter apenas sete artefatos é uma limitação da pesquisa e não significa que foi esgotado o portfólio de artefatos, podendo existir outros igualmente eficazes no apoio à gestão logística.

No decorrer da pesquisa, como objetivos adicionais, identificou-se a necessidade de mapear o perfil dos respondentes e de relacionar o padrão de desenvolvimento das organizações, em termos de estágios de MGL, CVO e quantidade de artefatos de controle gerencial utilizados, como as características do perfil da empresa. Por exemplo, verificar se o estágio atual de MGL ou CVO de uma empresa está relacionado com sua idade ou porte.

\subsection{Justificativas do estudo}

Segundo Castro (1978), os principais atributos do trabalho científico devem ser a originalidade, a importância e a viabilidade. 
Sobre a importância, esta pesquisa se justifica pelo papel que a atividade logística exerce tanto no ambiente microeconômico quanto macroeconômico. Lambert e Stock (1993, p. 6), afirmam que: Como um importante componente do PNB (Produto Nacional Bruto), a logística afeta a taxa de inflação, taxa de juros, produtividade, custo e disponibilidade de energia, além de outros aspectos da economia. Todavia, cabe ressaltar que esta pesquisa se restringe ao papel da atividade logística no ambiente das organizações.

Quanto à originalidade, o valor desta dissertação reside na análise da existência de associações entre dois modelos teóricos distintos. Segundo Martins (2001), a busca por associação entre variáveis é frequentemente um dos propósitos das pesquisas empíricas. Alguns trabalhos afirmam haver relação entre desempenho e estágio de MGL (LOCKAMY; MCCORMARK, 2004; ARYEE, 2008, MCCOMARK et al, 2008; OLIVEIRA, 2009), outros abordam a relação entre o CVO e a utilização de artefatos (DOWN, 1967; SCOTT, 1971; ADIZES, 1979; KIMBERLY, 1979; QUINN; CAMARON, 1983; MILLER; FRIESSEN, 1984; MOORES; YUEN, 2001; FREZATTI et al, 2009), porém, não foi encontrado na literatura estudos sobre a relação entre MGL e CVO.

Para garantir a viabilidade, foram desenvolvidos relacionamentos com entidades ligadas à atividade logística (Logicon - Centro de Pesquisa em Logística Integrada à Controladoria e Negócios, Revista Mundo Logística, Portal Supply Chain²), a fim de assegurar acesso a um número significativo de profissionais capacitados a responder as questões relacionadas à gestão logística e configuração organizacional. Essas entidades ajudaram na divulgação da pesquisa junto a profissionais de gestão logística.

\subsection{Contribuições da pesquisa}

A principal contribuição que se espera com este trabalho é proporcionar aos gestores um maior entendimento sobre o relacionamento entre os estágios de MGL e os estágios do CVO. Lester et al (2003, p. 340) afirmam que o valor do entendimento do estágio do ciclo de vida organizacional é a identificação das mudanças que ocorrem quando as organizações crescem e se desenvolvem.

\footnotetext{
${ }^{2}$ Página da internet especializado na divulgação de eventos e trabalhos nas áreas de logística de supply chain management disponível em (www.portalsupplychain.com.br)
} 
As atividades logísticas estão se tornando cada vez mais relevantes para o atendimento das metas das organizações. Nesse sentido, o presente trabalho é útil para que o gestor de logística possa considerar aspectos que influenciam a MGL, mas que não estão necessariamente inseridos no escopo da gestão da cadeia de suprimentos, ou seja, aqueles referentes ao CVO. Os resultados também são de interesse do gestor da organização que, apesar de não está envolvido diretamente com a atividade logística, pretende obter um maior entendimento sobre os processos logísticos e seus estágios de MGL, para alinhar as necessidades da gestão logística aos interesses estratégicos da sua área de atuação.

\subsection{Estrutura do trabalho}

O presente trabalho está estruturado em cinco capítulos. O primeiro consiste na introdução aos principais conceitos, apresentação da situação problema e questão de pesquisa, bem como os objetivos e as justificativas para o estudo.

No capítulo dois será apresentado o referencial teórico que fornece subsídios à aplicação da pesquisa empírica e discussão dos resultados. Foi dividido em quatro sessões: (2.1) Logística; Integração logística; e Gestão da cadeia de suprimentos; (2.2) Maturidade da gestão da cadeia de suprimentos; (2.3) Ciclo de vida organizacional; e (2.4) Utilização de artefatos de controle gerencial na gestão da cadeia de suprimentos.

Já no terceiro capítulo, será apresentada a metodologia para responder à questão de pesquisa. O capítulo contém algumas discussões metodológicas, apresenta e discute o instrumento de coleta de dados (questionário) e os métodos de tratamento e análise dos dados.

No capítulo quatro os resultados serão apresentados e discutidos. Contém análise do perfil da empresa e dos respondentes, classificação das empresas nos estágios de maturidade da gestão logística e do ciclo de vida organizacional, análise sobre as associações entre os estágios de desenvolvimento e relação entre esses estágios com a utilização de artefatos de controle gerencial. O capítulo cinco dedica-se às considerações finais desta dissertação. 


\section{REFERENCIAL TEÓRICO}

\subsection{Logística}

Poucas áreas de estudo têm um impacto tão significativo no padrão de vida da sociedade quanto a logística, no entanto, as pessoas não percebem o seu importante papel até que ocorram problemas no processo logístico (LAMBERT; STOCK, 1993, p.3), ou seja, quando determinado produto não chega à prateleira do supermercado, por exemplo.

A definição de logística mais recorrente em livros e publicações acadêmicas é a do Council of Supply Chain Management Professionals (CSCMP), a qual foi traduzida e publicada também pela ASLOG, Associação Brasileira de Logística, da seguinte forma:

Logística é uma parte da cadeia de abastecimento que planeja, implementa e controla com eficácia o fluxo e a armazenagem dos bens, dos serviços e das informações entre o ponto da origem e o ponto de consumo destes itens, a fim de satisfazer todas as exigências dos consumidores em geral.

Para Bowersox et al (2010, p. 4) logística é simplesmente o trabalho de mover e posicionar geograficamente os produtos. No entanto, os autores complementam afirmando que, para cumprir essa função, a logística envolve a coordenação de diversas atividades, como por exemplo: suprimento de materiais, gerenciamento de ordens, transporte de inventários, armazenamento, manipulação de materiais, embalagem, serviço ao cliente, etc. Para que a logística seja eficiente e eficaz, todas essas atividades devem ser coordenadas e integradas.

Ainda segundo Bowersox et al (2010, p. 22), a logística agrega valor para a cadeia de suprimentos quando os produtos são estrategicamente posicionados para que sejam vendidos. E para que esse processo atenda ao nível de serviço exigido pelo mercado, é preciso que os produtos pedidos sejam entregues aos clientes certos, na quantidade solicitada e com a qualidade requerida, no local, prazo e condições combinados (BIO, 2011).

\footnotetext{
${ }^{3}$ CSCMP: "The process of planning, implementing and controlling the efficient, cost-effective flow and storage of raw materials, in process inventory, finished goods, and related information from point-of-origin to point-ofconsumption for the purpose of conforming to customer requirements."
} 
Portanto, cada atividade do processo logístico contribui para gerar valor para a empresa e para a cadeia, e devem ser geridas estrategicamente, a fim de que as perdas de materiais e de informações entre os integrantes dessa cadeia sejam as menores possíveis.

O gerenciamento estratégico refere-se ao posicionamento dos recursos e desenho dos processos. Pode ser feito, por exemplo, adotando-se a gestão baseada em processo, definida por Chase et al (206, p. 53) como uma série de tarefas relacionadas, comumente direcionadas para um resultado maior.

Trkman et al (2007, p. 117) asseguram que organizações orientadas na gestão por processos apresentam um melhor desempenho do que aquelas com unidades funcionais, divisões ou departamentos. Lockamy e McCormack (2004, p. 273) afirmam que a gestão baseada em processos aumenta o nível de integração entre as empresas, reduzindo os conflitos entre elas.

Na adoção de uma gestão baseada em processos, a integração das atividades logísticas exerce um papel fundamental. A logística integrada serve para sincronizar toda a cadeia de suprimentos como um processo contínuo e é essencial para assegurar a eficácia da conectividade na cadeia de suprimentos (BOWERSOX et al, 2010, p. 4). Para Sweet e Lee (2009, p. 5) a integração logística requer coordenação e planejamento.

A integração logística pode ser adotada tanto no nível interno (das áreas) como externo da organização (nas relações entre compradores e vendedores). Chen et al (2009, p. 65) creem que existem muitas diferenças entre os conceitos de integração interna e externa, os quais deveriam ser tratados de forma diferente.

\subsubsection{Integração logística}

Para Chen et al (2009, p. 63) a integração da logística é um componente chave da gestão da cadeia de suprimentos. Entretanto, os autores advertem que diferentes organizações requerem abordagens diversas para implantação da integração e sem a clara definição dos limites, haverá muitas dificuldades para tratar dos problemas envolvidos na integração interna e externa (CHEN et al, 2009, p.65). Portanto, não há uma maneira única de realizar a integração logística, pois sua adoção depende do contexto organizacional. 
O objetivo da logística integrada é desenhar a estrutura de um processo logístico de forma que possa atender ao nível de serviço requerido pelo cliente desse processo, ao menor custo total possível (BIO, 2011).

O planejamento da integração logística interna e externa envolve processos complexos e que devem ser conduzidos em etapas distintas e sequenciais, sendo que a inicialmente é preciso que os processos sejam integrados internamente e depois com o ambiente externo (CHEN et al, 2009, p. 65; Stevens, 1989, p. 10).

\section{a) Integração interna:}

Integração interna é a competência para integrar os trabalhos desenvolvidos internamente de maneira consistente para atender as necessidades dos clientes (STANK et al, 2001, p. 1). Portanto, a integração interna tem o objetivo de tornar às operações internas mais eficientes a fim de melhor atender os clientes e consumidores.

Integração interna envolve o compartilhamento de serviços, informações, recursos materiais e humanos, responsabilidades e colaboração mútua entre as diversas áreas funcionais da organização. Todo esse processo deve ser gerenciado com bastante atenção, pois as decisões que nele ocorrem são de níveis operacionais, táticos e estratégicos (SWEET; LEE, 2009).

Na visão de Sweet e Lee (2009, p. 5) coordenação e planejamento são dois aspectos a serem considerados no processo de integração interna. Segundo os autores, coordenação refere-se à habilidade de a empresa integrar seus processos dentro da organização enquanto que planejamento é a habilidade de integrar o processo interno utilizando informações de outros parceiros da cadeia de abastecimento.

\section{b) Integração externa:}

A integração externa é a competência para integrar de maneira consistente, o trabalho desenvolvido fora da empresa com aquele desenvolvido internamente (STANK et al, 2001). Nessa visão, os autores abrangem todos os parceiros da cadeia de abastecimento: fornecedores, clientes, prestadores de serviços, etc. Na definição dos autores está implícita a importância do planejamento das atividades internas para o sucesso da integração externa. 
Outro conceito fundamental para o sucesso da integração externa é a cooperação entre os agentes envolvidos. Larson (1994, p. 5), destaca que a integração externa ocorre entre a firma e seus parceiros externos, o que destaca a importância de haver cooperação entre os estágios da cadeia de abastecimento.

O projeto de integração interna é uma iniciativa da organização, controlada e planejada por ela, porém, o projeto de integração externa depende também do desejo e da cooperação dos agentes externos, o que o torna mais complexo. Para o sucesso da integração externa os parceiros devem enxergar quais os benefícios adquiridos por sua cooperação.

Quando a integração interna e externa dos processos logísticos é implantada de maneira bem sucedida e há planejamento, coordenação e cooperação nesses processos, cria-se um ambiente favorável à implantação de uma gestão da cadeia de suprimentos (GCS).

\subsubsection{Gestão da cadeia de suprimentos}

A gestão da cadeia de suprimentos pressupõe a colaboração entre empresas para impulsionar o posicionamento estratégico e para melhorar a eficiência operacional (BOWERSOX et al, 2010, p. 4). Para o Institute of Management Accountants (IMA, 1999, p. 3), a gestão integrada da cadeia de suprimentos requer o desenvolvimento de relações próximas entre os parceiros da cadeia, além da gestão do fluxo de produtos e informações entre as empresas. Essa é a principal diferença entre o conceito de logística e GCS.

Ballou (2006, p. 380) explica que a GCS é uma evolução da discussão sobre gestão logística e representa o foco atual de pesquisas em gestão empresarial. Para o autor a GCS possui três dimensões: administração de processos, coordenação interfuncional, e coordenação interorganizacional. A GCS envolve toda a empresa, seus fornecedores, seus clientes, os fornecedores dos fornecedores e os clientes dos clientes.

Portanto, o sucesso no planejamento das atividades logísticas, a integração dos processos internos e o estabelecimento de parcerias estratégicas podem conduzir as organizações ao nível de integração logística (com os principais parceiros). Todavia, para atingir o nível de GCS é necessária a gestão do relacionamento com os parceiros da cadeia de suprimentos, o 
que torna esse caminho bastante complexo, dado o universo de variáveis e interesses diversos, por vezes conflitantes, que influenciam as relações entre os elos da cadeia.

Exatamente por conta da complexidade da implantação da gestão da cadeia de suprimentos, foram desenvolvidos modelos de maturidade, com objetivo de mensurar o estágio de desenvolvimento da gestão logística nas empresas.

O modelo de maturidade da gestão logística (MGL) utilizado nesta dissertação tem o objetivo de identificar determinados atributos presentes na gestão da cadeia de suprimentos em empresas brasileiras, a fim de classificar o seu estágio atual de desenvolvimento. No entanto, antes de apresentar o modelo de MGL utilizado nesta pesquisa, faz-se necessário introduzir o conceito de maturidade de processos.

\subsection{Maturidade de processos}

Lambert et al (2008, p. 114) argumentam que a gestão da cadeia de suprimento é caracterizada por três requisitos: 1) necessita ser interfuncional; 2) necessita ser orientado a processos; e 3) necessita incluir toda a atividade de gestão das interações entre clientes e fornecedores. Rodrigues et al (2006, p. 2) complementam, afirmando que gerenciar a cadeia de suprimentos é gerenciar os processos que envolvem os parceiros ao longo do canal.

Para Chase et al (2006, p. 53), a gestão de processos é a gestão de "uma série de tarefas relacionadas, comumente direcionadas para um resultado maior." $\mathrm{O}$ desenvolvimento (ou amadurecimento) da gestão logística está direcionado para atender aos objetivos estratégicos da empresa, ou seja, agregar valor e criar vantagem competitiva.

Qualquer processo pode agregar novas atribuições e competências ao longo do tempo à medida que o ambiente onde está inserido torna-se mais complexo (Lockamy; McComark, 2004, McComark et al, 2009, Oliveira, 2009). A quantidade de atribuições e competências presentes no processo determina seu estágio de maturidade. Segundo Lockamy e McComark (2004, p. 272), o conceito de maturidade de processos propõe que um processo possui um ciclo de vida que é avaliado pela extensão na qual ele é explicitamente definido, gerenciado, medido e controlado. 
Entre 1987 e 1997, um grupo ligado à universidade de Carnegeire Mellon, Pittsburgh, denominado Software Engineering Institute (SEI), desenvolveu um modelo de maturidade para implementação de software, o modelo foi denominado Capability Maturity Model (CMM), e sua versão 1.1 foi lançada em 2001. No modelo CMM, à medida que os processos críticos para o sucesso de sistemas tornavam-se mais complexos e integrados, eles alcançavam estágios de desenvolvimento mais avançados.

Em 2004, os professores Archie Lockamy e Kevin McComark, da universidade Samford e do Alabama, respectivamente, desenvolveram um modelo para mensurar a maturidade da gestão logística das empresas inspirado no modelo de maturidade SEI (2002).

\subsubsection{Maturidade de processos logísticos}

Atualmente, existem diversos modelos que visam mensurar o estágio de maturidade da gestão logística. Um deles foi desenvolvido por Stevens (1989), e contém quatro estágios de maturidade: (1) linha base; (2) integração funcional; (3) integração interna; e (4) integração externa. Nesse modelo, os estágios do processo logístico partem de um ambiente primário, onde as atividades e os objetivos das diversas áreas funcionais não estão integrados, e alcançam o maior nível de maturidade quando os parceiros da cadeia de valor trocam informações estratégicas e desenvolvem parcerias de longo prazo, com foco no cliente.

Outro modelo de maturidade contendo quatro estágios foi proposto pela consultoria Performance Measurement Group - (PMG, 2007), sendo nomeados de acordo com cada etapa da GCS: (1) foco funcional; (2) integração interna; (3) integração externa; e (4) colaboração entre empresas da cadeia. Sobre esse modelo, Frederico e Martins (2010), comentam que à medida que uma cadeia de abastecimento atinge um maior nível de maturidade no processo logístico, suas competências operacionais aumentam e há um impacto positivo no desempenho dessa cadeia.

Já Aryee et al (2008) afirmam que a maturidade da gestão logística está relacionada com o nível de integração na cadeia e propõem um modelo de maturidade que não é baseado em estágios, e sim em oito competências que acreditam que devem estar presentes na gestão da 
cadeia de suprimentos: otimização, integração, sincronização, colaboração interna, colaboração externa, processo de conhecimento, tecnologia e desempenho.

O modelo de maturidade da gestão logística (Supply Chain Maturity Model), desenvolvido por Lockamy e McCormack (2004), é composto por cinco estágios de maturidade e propõe que um processo tem um ciclo de vida medido pela extensão em que é definido, gerenciado, mensurado, controlado e efetivado (LOCKAMY; MCCOMARK, 2004, p. 272).

O modelo de MGL de Lockamy e McCormack (2004) será analisado com maior nível de detalhe, uma vez que constitui a base do modelo de Oliveira (2009), utilizado nesta dissertação. Tem por objetivo verificar a aderência da gestão logística às práticas recomendadas pelo Council of Supply Chain Management Professionals (CSCMP), as quais foram reunidas em um documento consolidado denominado SCOR (Supply Chain Operation Reference model), que, por sua vez, tem o propósito de fornecer a estrutura básica para gestão da cadeia de suprimentos (LOCKAMY; MCCOMARK, 2004, p. 275).

A utilização das práticas recomendadas no SCOR como base para o modelo proposto de MGL é devido a sua grande aceitação tanto no ambiente profissional quanto acadêmico (LOCKAMY MCCOMARK, 2004, p. 275). O SCOR é reconhecido por muitas empresas integrantes do Supply Chain Council (CSC), como uma ferramenta para garantir vantagem competitiva aos parceiros de uma cadeia de suprimentos (RODRIGUES et al, 2006, p. 3).

Para Stewart (1997), o SCOR é um modelo de estrutura interfuncional criado para auxiliar as organizações a tornarem a gestão logística mais eficaz. Segundo Lockamy e McComark (2004, p. 1192) esse modelo fornece uma linguagem dirigida a processos para orientar a comunicação entre os parceiros da cadeia de suprimentos nas seguintes áreas de decisão: planejamento, suprimento, produção, distribuição e retorno.

Conforme Stewart (1997), dentre as vantagens na utilização do modelo SCOR destacam-se:

- Avaliação efetiva de processos próprios;

- Comparação de desempenho com outras empresas;

- Busca especificar as vantagens competitivas;

- Uso de informações de benchmarking para melhorar as atividades; 
- Quantificação dos benefícios de implementação da mudança;

- Identificação de ferramentas de software para prover necessidades específicas;

Rodrigues et al (2006, p. 4) fornecem uma descrição simplificada de quatro dos principais processos de gestão logística que compõem o SCOR:

a) Planejamento: inclui o planejamento do nível de estoque, da distribuição, da produção e da capacidade de atender à demanda.

b) Suprimento: aquisição de matéria-prima, qualificação e certificação de fornecedores, monitoramento de qualidade e negociação de contratos.

c) Produção: fabricando o produto final, testando, embalando, mudanças nos processos, lançamento e apropriação de produtos.

d) Distribuição: gerenciamento do pedido e crédito, gerenciamento do armazém, do transporte, da expedição e atendimento. Criação de base de dados de consumidores, produtos e preços.

O modelo de maturidade de processo logístico desenvolvido por Lockamy e McComark (2004) considera apenas as áreas de decisão planejamento, abastecimento, fabricação e distribuição, porque está baseada na versão 4.0 do SCOR, vigente à época da construção do modelo. Atualmente o SCOR inclui uma quinta área de decisão: a logística reversa.

Lockamy e McCormack (2004) realizaram ainda diversos encontros com profissionais ligados à atividade logística, principalmente de gestão da cadeia de suprimentos, com a finalidade de aproximar o modelo da realidade profissional.

Embora tenha conquistado certa aceitação e tenha sido publicado em periódicos importantes da área o modelo de Lockamy e McCormack (2004) apoia-se basicamente em métricas subjetivas para classificar as empresas nos níveis de maturidade (OLIVEIRA, 2009, p. 73).

\subsubsection{Modelo de maturidade da gestão logística de Oliveira (2009)}

Com o objetivo de reduzir a subjetividade do modelo de maturidade de Lockamy e McComark (2004), o professor Marcos P. V. Oliveira, então doutorando da Universidade Federal de Minas Gerais (UFMG), desenvolveu-o quantitativamente em sua tese a fim de 
torná-lo mais objetivo em termos de classificação dos estágios. Sua proposta foi identificar os pontos de transição entre os estágios de maturidade, baseando-se nos escores individuais que determinam em qual deles a empresa se localiza (OLIVEIRA, 2009).

Durante esse processo de desenvolvimento de um novo modelo, mais objetivo, baseado em parâmetros quantitativos, o autor contou com apoio de um grupo de pesquisadores de diversos países: EUA, Croácia, Eslovênia, Bélgica e Brasil (OLIVEIRA, 2009, p. 78). O resultado foi a concepção de um novo modelo de MGL denominado SCPM3, Supply Chain Process Management Maturity Model, contendo cinco estágios de maturidade, balizados por pontos de transição.

Para encontrar tais pontos de transição, Oliveira (2009) trabalhou com o questionário do modelo de Lockamy e McComark (2004), composto por 90 questões, e conseguiu uma amostra com 788 empresas, sendo 478 brasileiras e 310 de outros países - Estados Unidos, Canadá, Reino Unido e China (OLIVEIRA, 2009, p. 81).

Os estágios de maturidade foram determinados e validados por métodos quantitativos sendo que as competências requeridas no SCOR devem ser apresentadas de maneira cumulativa no fluxo normal da gestão logística, a fim de que a empresas atinjam os níveis mais elevados de maturidade. Os cinco estágios foram assim denominados: (1) Fundação; (2) Estrutura; (3) Visão; (4) Integração e (5) Dinâmica.

O autor aplicou análise fatorial nas respostas dos questionários recebidos com o objetivo de agrupar as questões. Por meio desse procedimento, as questões foram agrupadas em treze construtos (competências). Em seguida realizou-se a análise de conglomerado nas empresas, utilizando seus escores individuais, e encontraram-se cinco grupos Os pontos de transição entre os grupos foram determinados considerando a distância média entre os centroides desses cinco agrupamentos. A validação dos treze constructos e sua relação com cada estágio de maturidade foi realizada com utilização da técnica modelagem de equações estruturais.

Dentre as inovações desse modelo de MGL, destacam-se a compreensão da dinâmica de precedência entre as competências da gestão da cadeia de suprimentos e a identificação dos pontos chaves de transição entre os estágios (OLIVEIRA, 2009, p. 128). 
O modelo MGL utilizado nesta dissertação é, portanto, aquele proposto por Oliveira (2009), que tem o objetivo de servir como um instrumento para orientar os gestores sobre o estágio atual de MGL de sua empresa e indicar o caminho para atingir os níveis de maturidade desejados (McCOMARK et al, 2009, p. 792).

De acordo com os pontos de transição do modelo, empresas com escore inferior a 203 devem ser classificadas no nível Fundação, entre 203 e 257, no nível Estrutura, entre 258 e 303, no nível Visão, entre 304 e 354, no nível Integração e, aquelas com escore superior a 354, no nível Dinâmica. A Ilustração 1 exibe os pontos de transição entre os estágios, bem como as competências que devem ser apresentadas de maneira cumulativa.

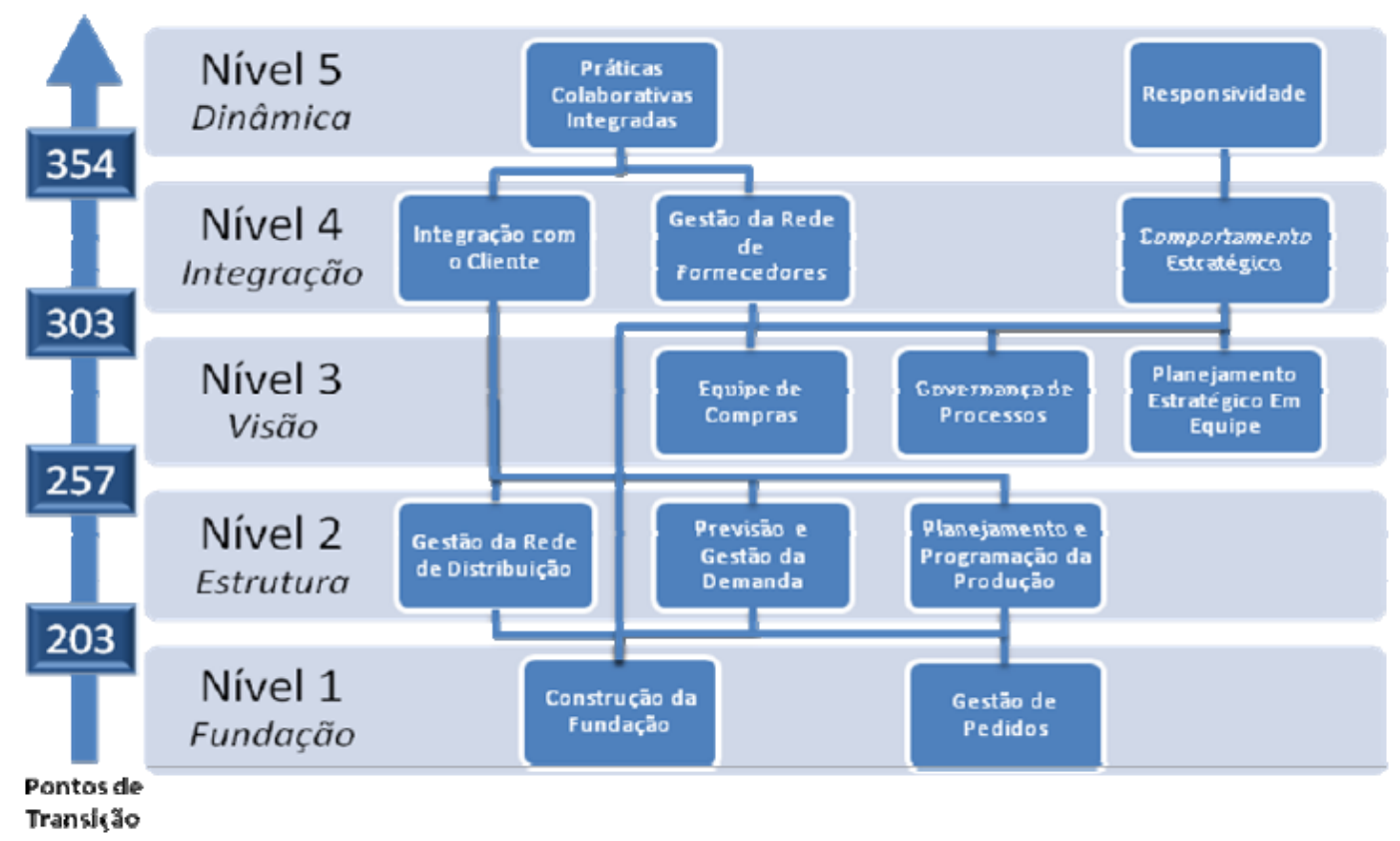

Ilustração 1: Modelo de Maturidade da Gestão Logística de Oliveira (2009)

Fonte: Oliveira (2009, p. 111)

Oliveira (2009, p. 111-116) define as características de cada nível de maturidade e das empresas neles classificados, da seguinte forma:

Nível 1 - Fundação: Caracterizado pela construção de uma estrutura básica, buscando criar uma fundação para os processos, com o objetivo de evitar procedimentos contingenciais e reações desordenadas, buscar a estabilização dos processos e documentar os fluxos. Neste nível, os parceiros críticos para o negócio são identificados e práticas de gestão de pedidos são implementadas 
considerando as restrições de capacidade e alinhamento de recursos com expectativas de produtos e/ou serviços por parte dos clientes da organização.

Empresas posicionadas no nível Fundação possuem as seguintes características:

- Podem apresentar ineficiência quando há necessidade de implementar mudanças nos processos, gerando, como resultado, desgaste entre os profissionais envolvidos. As mudanças são lentas, demandam muito esforço de replanejamento e provável desperdício de recursos.

- Há a sensação de que os clientes não estão satisfeitos com os tempos de entrega. Os compromissos com os clientes não podem ser considerados confiáveis, e a empresa não possui controle adequado do que foi pedido e ainda não foi entregue.

- Não estão preparadas para gerar entregas aos clientes quando algum tratamento especial é exigido. Os processos não são flexíveis e, portanto, lançam mão de recursos alternativos, com alto custo para organização.

- Por falta de previsões da demanda adequadas e de integração interna, é comum os vendedores prometerem mais do que a empresa consegue entregar em termos da sua capacidade produtiva e dos níveis de estoque. Adicionalmente, a empresa não tem controle e não documenta devidamente as situações de ruptura.

- Ainda não possuem seus processos de colocação de pedidos, distribuição e compras adequadamente documentados e, portanto, tais fluxos de processos não podem ser devidamente controlados.

- Os sistemas de informação da empresa não suportam de maneira adequada todos os processos na cadeia de suprimentos.

- Não possuem fornecedores considerados estratégicos para proverem produtos e serviços, e por extensão lógica, os níveis de serviço com os fornecedores não são apropriadamente acordados, entendidos e documentados, com prejuízos do ponto de vista de controle.

Nível 2 - Estrutura: Os processos da empresa começam a ser estruturados para posteriormente serem integrados. Itens de controle são implementados nos processos de gestão da demanda, planejamento e programação da produção e na 
gestão da rede de distribuição. À jusante, práticas de gestão da rede de distribuição começam a ser estruturadas e os processos passam a ser progressivamente mais bem definidos. A demanda passa a ser avaliada com mais critério. Em outra direção, os processos de planejamento e programação da produção passam a ser mais estruturados e baseados nos processos de previsão e gerenciamento da demanda.

Empresas posicionadas no nível Estrutura possuem as seguintes características:

- Investem na documentação dos fluxos de planejamento e programação, desenvolvem métricas para verificar a aderência do planejamento à programação da produção e às necessidades do negócio. Os planos começam a ser desenvolvidos no nível de detalhe de cada item ou serviço a ser produzido.

- Os planos de produção começam a se integrar ao longo das divisões da empresa e as metodologias utilizadas consideram as restrições de capacidade do sistema de operações da organização.

- Os sistemas de informação passam a suportar as operações e a se integrar melhor com os demais processos da organização.

- Passam a avaliar a demanda por cada item/serviço com base no histórico de pedidos e possuem um processo de previsão e gestão de demanda implementado e formalizado.

- Métodos matemáticos e estatísticos atuam como base para o planejamento da distribuição e das previsões de demanda, juntamente com informações dos clientes.

- As previsões são atualizadas com frequência e são confiáveis. As previsões têm sua acurácia medida e atuam como base para o desenvolvimento de planos e de compromissos com clientes.

- As futuras mudanças nos processos têm seu impacto avaliado com detalhe antes de serem implementadas.

- Cada nó da cadeia de distribuição passa a ter medidas para avaliação de desempenho e princípios de controle são implementados. Práticas de reabastecimento automático passam a ser mais frequentes na rede de distribuição. 
- Os processos de distribuição são medidos e controlados, e utilizados para se medir e recompensar os agentes econômicos da cadeia.

Nível 3 - Visão: Os processos passam a ter donos, que são responsáveis pela sua gestão e desempenho. Os processos de compras são acompanhados por uma equipe que avalia estrategicamente as aquisições de forma alinhada com os interesses das áreas: comercial e de operações da empresa. Neste nível, a organização começa a construir as bases para assumir um comportamento decisivamente e deliberadamente mais estratégico, considerando uma visão ampliada dos fluxos de materiais, informação e meios de pagamento na cadeia de suprimentos.

Empresas posicionadas no nível Visão possuem as seguintes características:

- Há uma equipe de compras formalmente designada e que se reúne regularmente e atua em conjunto com outras funções da organização, como operação e vendas. O processo de comprometimento de pedidos possui um responsável, que garante o atendimento das promessas feitas ao cliente. Da mesma forma, os processos-chave de distribuição, planejamento da cadeia de suprimentos, planejamento estratégico das operações, planejamento de demanda, compras e operações possuem responsáveis formais.

- A equipe de planejamento estratégico das operações reúne-se regularmente e utiliza ferramentas de análise adequadas para identificar o impacto das alterações antes que tais alterações sejam implementadas.

- Há um processo de planejamento das estratégias das operações devidamente documentado. Quando a equipe se reúne e faz ajustes nas estratégias, estes são devidamente atualizados nos documentos formais do processo em questão.

Nível 4 - Integração: A empresa busca construir uma colaboração com seus parceiros de negócio na cadeia de suprimentos. Os processos organizacionais passam a se integrar com os processos dos fornecedores e clientes em uma plataforma colaborativa. As previsões passam a ser desenvolvidas em maior nível 
de detalhe, considerando as demandas de cada cliente individualmente. O relacionamento com os parceiros à montante na cadeia de suprimentos começa a se tornar mais sólido e integrado. As empresas, a partir de um conjunto de métricas sólidas e dados saudáveis sobre os fluxos dos processos, começam a lançar mão de abordagens analíticas e a atuar de forma mais estratégica com seus parceiros na cadeia de suprimentos.

Empresas posicionadas no nível Integração possuem as seguintes características:

- Começam a desenvolver em seus processos a capabilidade de responder à demanda trabalhando de forma puxada.

- As funções de vendas, operações e distribuição colaboram no processo de planejamento e programação.

- As informações sobre planejamento dos clientes passam a ser consideradas como entradas no seu planejamento. As previsões são desenvolvidas para cada cliente ou segmento de clientes da empresa, individualmente.

- As mudanças nos processos são implementadas de forma suave, sendo guiadas por um processo documentado na organização.

- Colaboram com seus fornecedores no desenvolvimento seus dos planos de produção.

- Medidas e controles são implementados para avaliar o desempenho dos fornecedores. Estes possuem acesso a níveis de estoque da empresa contratante e as informações sobre planejamento e programação são compartilhadas.

- Fornecedores críticos são considerados parceiros e têm amplo acesso às informações da produção da empresa cliente.

- A equipe de planejamento estratégico, estabelecida no nível anterior, agora avalia continuamente o impacto das suas estratégias com base em medidas de desempenho previamente estabelecidas para a cadeia de suprimentos da empresa.

- A equipe de planejamento estratégico envolve-se diretamente na seleção de membros e parceiros da cadeia de suprimentos e participa ativamente nos fluxos de relacionamento com clientes e fornecedores. 
- A equipe de planejamento estratégico avalia a lucratividade de cada cliente e de cada produto individualmente e, com base em tal avaliação, define prioridades específicas e alocação de recursos para clientes e produtos.

Nível 5 - Dinâmica: Caracterizado por uma integração sistêmica e estratégica da cadeia, em que os processos suportam práticas colaborativas entre os parceiros e geram sustentação para que a cadeia atue de maneira responsiva diante das variações do mercado. A cadeia passa, então, a se comportar dinamicamente, evoluindo continuamente seus processos a partir de uma avaliação de seus indicadores-chave de desempenho e reagindo de forma sincronizada e rápida às mudanças no contexto competitivo.

Empresas posicionadas no nível Dinâmica possuem as seguintes características:

- As funções de vendas, marketing, distribuição e planejamento colaboram entre si no processo de atendimento dos pedidos e no desenvolvimento de previsões.

- O processo de atendimento de pedidos está integrado aos demais processos da cadeia de suprimentos.

- Os processos de gestão de demanda e o de planejamento e programação da produção estão totalmente integrados.

- Estabelecem um relacionamento próximo com seus clientes e possuem controle sobre restrições de capacidade e demanda do sistema.

- Atendem às demandas de curto prazo dos seus clientes e atuam de maneira responsiva a essa demanda real.

Apesar de o modelo ajudar os gestores a perceber o estágio atual de desenvolvimento da gestão logística das empresas e a identificar as competências que faltam para se atingir estágios de maturidade maior, deve-se reconhecer como limitação, que se trata de uma simplificação da realidade e ele não captura toda a complexidade das cadeias. A consultoria PMG (Performance Measurement Group) analisou 121 cadeias e concluiu que existe correlação entre a complexidade da cadeia e o nível de maturidade da gestão logística (de acordo com um modelo desenvolvido por eles), sendo que cadeias com práticas mais maduras de gestão conseguem reduzir a complexidade, têm melhor desempenho (PMG, 2007, p. 34). 


\subsection{Ciclo de vida organizacional}

Miller e Friesen (1984, p. 1161) afirmam que uma quantidade recorrente de transações é esperada quando uma organização jovem, pequena e simples se torna velha, grande e complexa. Nesse sentido, espera-se que as mudanças que ocorrem no ambiente organizacional sigam um padrão previsível que pode ser caracterizado por estágios de desenvolvimento (QUINN; CAMERON, 1983, p. 33).

Existem diversos modelos que visam detectar o estágio atual do ciclo de vida organizacional (CVO) na literatura sobre estudos organizacionais e contabilidade gerencial (DOWN, 1967; SCOTT, 1971; QUIN; CAMARON, 1972; LYDEN, 1975; ADIZES, 1979; KIMBERLY, 1979; MILLER; FRIESEN, 1984; LESTER et al, 2003).

Cada estágio do CVO apresenta uma configuração de determinados atributos e, embora a taxonomia e o número de estágios possam variar de acordo com o modelo de cada autor, a essência dos modelos teóricos permanece a mesma (LESTER et al, 2003, p. 341), ou seja, os pesquisadores classificam os estágios do ciclo de vida de uma organização por meio da identificação de determinadas características e atributos desta.

O modelo de ciclo de vida utilizado nesta dissertação é o de Lester et al (2003). Nesse modelo, as características ou atributos que definem o estágio do ciclo de vida de cada organização são: ambiente organizacional, modelos de decisão, estrutura organizacional, processamento de informações e distribuição do poder.

Há quatro justificativas para a escolha desse modelo: (i) é um dos modelos mais utilizados em estudos científicos, segundo Correia et al (2010); (ii) não foi desenvolvido para uma indústria específica (LESTER et al, 2003, p. 350); (iii) possui um questionário mais compacto com apenas vinte questões para capturar a percepção dos gestores com relação aos atributos que definem cada ciclo de vida; (iv) é um modelo que está sendo estudado por uma equipe de pesquisadores experientes da Universidade de São Paulo, permitindo troca de ideias e contribuições sobre a metodologia. 
O modelo de CVO proposto por Lester et al (2003) é composto por cinco estágios: (1) Existência; (2) Sobrevivência; (3) Sucesso; (4) Reativação; e (5) Declínio. Segundo os autores, cada estágio possui as seguintes características e atributos:

\section{1) Estágio 1: Existência.}

Este estágio marca o começo do desenvolvimento organizacional. O foco é a sua viabilidade ou simplesmente a identificação de um grupo suficiente de clientes para garantir a existência da organização. As decisões e o controle estão nas mãos de uma pessoa, ou um grupo pequeno de pessoas, e o ambiente é considerado incerto e não analisável. Organizações nesse estágio tendem a criar o seu próprio ambiente.

\section{2) Estágio 2: Sobrevivência.}

Assim que as organizações migram para o segundo estágio elas buscam o crescimento, desenvolvem alguma formalização da estrutura, e estabelecem suas próprias competências individuais. Nesse estágio, os objetivos são formulados rotineiramente, e o primeiro é gerar receitas suficientes para continuar as operações e financiar o crescimento a fim de manter-se competitivo. O estágio de sobrevivência fornece algumas alternativas interessantes: certas organizações conseguem crescer e prosperar o suficiente para entrar no estágio três, outras conseguem atingir retornos marginais em alguns períodos, e há aquelas que acabam fracassando na missão de gerar receita suficiente para garantir a sobrevivência. A maioria das organizações nesse estágio já consegue analisar de alguma forma o ambiente externo.

\section{3) Estágio 3: Sucesso.}

Normalmente chamado de maturidade, o estágio de sucesso representa uma forma organizacional onde a formalização e o controle burocrático são as normas. Um problema comum nesse estágio é o que os americanos chamam de "red tape". Trata-se do excesso de burocracia em grandes organizações. As descrições dos trabalhos, políticas e procedimentos, e os relacionamentos de subordinação na hierarquia ficam muito mais formalizados e lentos. Essas organizações passaram pelo teste de sobrevivência, crescendo até o ponto em que começam a proteger o que já conquistaram em vez de investir em novos territórios. O topo da gestão foca no planejamento e na estratégia, deixando as operações para os gerentes intermediários. O ambiente externo é visto como analisável. 


\section{4) Estágio 4: Reativação.}

As organizações no estágio de reativação desejam obter crescimento rápido, em que a colaboração e o trabalho em equipe promovem inovação e criatividade. A adoção de uma estrutura matricial favorece o surgimento de um ambiente criativo e as decisões são bastante descentralizadas. A organização ainda é grande e burocrática, porém seus membros são encorajados a respeitarem as normas e regulamentos internos sem adotar uma postura burocrática. As necessidades dos clientes são colocadas acima das necessidades dos membros da organização.

\section{5) Estágio 5: Declínio.}

Embora as organizações possam existir em qualquer estágio, o de declínio pode causar a sua extinção. É caracterizado por disputas políticas e de poder, pois os membros da organização passam a concentrar mais atenção nos seus objetivos pessoais do que nos organizacionais. Em alguns casos, a incapacidade de atender as demandas externas leva a uma experiência de perda de participação de mercado e ausência de lucros. O controle e as decisões tendem a retornar para as mãos de algumas pessoas por conta do desejo de poder e influência.

Os atributos identificados em cada estágio do ciclo de vida são assim definidos (LESTER et al, 2003, p. 343):

\section{i) Ambiente organizacional:}

Refere-se à composição geral da organização, incluindo o seu tamanho, número de donos ou partes interessadas, como os clientes influenciam as decisões, a heterogeneidade do mercado onde atua etc. Idade e tamanho podem ter papel importante na identificação do desenvolvimento do ciclo de vida. No entanto, idade e estágio de desenvolvimento foram citados por Lippitt e Schmidt (1967) como fracamente correlacionados e algumas organizações grandes têm uma gestão tão centralizada que podem aparentar ser muito menores do que realmente são. Adicionalmente, um estágio de desenvolvimento não tem uma duração exata, pois alguns deles são superados rapidamente enquanto outros se prolongam por um período maior (CAMERON; WHETTON, 1981; MILES; RANDOLPH, 1980). 


\section{ii) Modelo de decisão:}

Normalmente diferem dependendo do nível de participação dos gerentes nas decisões. Existe a tendência da organização se tornar mais participativa à medida que se desenvolve (MCNAMARA; BADEN-FULLER, 1999). Outro fator que influencia o modelo de decisão é a sua própria estratégia, que pode ser do tipo prospector, defensiva ou voltada para a inovação.

\section{iii) Estrutura organizacional:}

Pode variar de simples a complexa, departamental ou divisional, e informal ou formal. Uma consideração de importância particular nos problemas relacionados à estrutura está no processamento de informação, concentração de poder e a organização departamental. Cada um desses três problemas foi classificado por Miller e Friesen (1984) como mais complexos à medida que as organizações avançam nos primeiros quatro estágios do ciclo de vida.

\section{iv) Processamento de informações:}

Este é um forte indicador do CVO (LESTER et al, 2010, p. 349). No estágio Existência o processamento de informações é simples e informal, no Sobrevivência ele facilita a comunicação interna da organização. No estágio Sucesso o processamento de informações é sofisticado e importante, enquanto que no Reativação ele torna-se complexo e integrado com o mercado. Já no estágio Declínio o os sistemas não são utilizados de maneira plena.

\section{v) Distribuição do poder:}

Refere-se a forma como a organização é administrada. Nos estágio Existência a principal característica é a concentração do poder nas mãos do fundador. No Sucesso, há distribuição das decisões entre proprietários e investidores. A partir do estágio Sucesso o poder é distribuído por um grande número de acionistas.

Para operacionalizar a verificação desses construtos nas empresas, os autores desenvolveram um questionário com 20 perguntas (indicadores), sendo que cada construto possui de três a seis indicadores, conforme demonstrado no capítulo 3. 


\subsubsection{Relação entre estágios de CVO e Contabilidade Gerencial}

Diversos trabalhos comprovam que empresas em diferentes estágios do CVO possuem características diferenciadas em termos de desenho do sistema de controle, utilização de ferramentas e artefatos gerenciais, bem como com o desempenho financeiro e operacional, (QUINN; CAMERON, 1983; MILLER; FRIESSEN, 1984; MOORES; YUEN, 2001; LESTER et al, 2003; FREZATTI et al, 2009; JUNQUEIRA, 2010).

Quim e Cameron (1983) discutem a relação que existe entre o desenvolvimento do ciclo de vida organizacional e a eficácia operacional. Em um estudo longitudinal, demonstraram que contingências externas afetam a organização ao longo do tempo, induzindo adaptações internas orientadas para a eficácia.

A clássica publicação de Miller e Friesen (1984) consiste em um estudo longitudinal com utilização de 54 variáveis para mensurar as mudanças na estratégia, situação, estrutura e estilo de tomada de decisão. Os autores propõem um modelo com cinco estágios de ciclo de vida (Nascimento, Crescimento, Maturidade, Reativação e Declínio), em que o Declínio pode ocorrer em qualquer empresa após o Nascimento, e cada um dos estágios Crescimento, Maturidade e Reativação duram, pelo menos, 10 anos.

Moores e Yuen (2001) replicaram o modelo de Miller e Friesen (1984) para empresas australianas do setor de calçados a fim de verificar se havia mudanças no sistema de controle gerencial dessas empresas em diferentes estágios do ciclo de vida. Constataram que o nível de formalização dos sistemas de controle gerencial entre os estágio é diferente, sendo que o seu maior nível é observado no estágio Sobrevivência.

Lester et al (2003) desenvolvem um modelo de ciclo de vida composto de cinco estágios a partir daquele proposto por Miller e Friesen (1984), porém com um questionário contendo apenas 20 questões. Constataram que há associação entre estágios de ciclo de vida, estratégia competitiva e o nível de satisfação com o próprio desempenho.

Frezatti et al (2009) utilizam o modelo desenvolvido por Lester et al (2003) para realizar pesquisa com empresas brasileiras, a fim de identificar se há associação entre estágios de ciclo de vida e formalização do processo de planejamento, que inclui o planejamento estratégico, 
orçamento e o controle orçamentário. Verificaram que existe uma associação entre estágios do ciclo de vida e níveis de formalização do processo de planejamento.

Junqueira (2010) investigou se havia associação entre fatores contingenciais internos e externos (o estágio do ciclo de vida organizacional é um fator contingencial externo) e as características do sistema de controle gerencial que poderiam levar a um desempenho diferenciado. Constatou que há associação entre fatores contingenciais e o desenho do sistema de controle gerencial, e que a configurações de fatores contingenciais estão associadas com o maior desempenho.

A comprovação empírica dessas associações corrobora a necessidade de maiores investigações e de um aprofundamento no estudo da teoria do CVO, para identificar outros fenômenos que possivelmente estejam associados ao ciclo de vida das empresas, como, por exemplo, os estágios de maturidade do processo logístico.

\subsection{Utilização de artefatos de controle gerencial na gestão logística}

Nessa seção, serão apresentados e discutidos sete artefatos de controle gerencial que, se presentes na organização, podem impactar a eficiência da gestão logística. A seleção desses artefatos levou em consideração a relação entre utilização da ferramenta e melhorias na gestão da cadeia de suprimentos e consequente aumento do desempenho operacional e financeiro. Realizou-se uma pesquisa nos principais periódicos para buscar trabalhos que relacionam a esses temas. Cabe destacar que pode haver outros artefatos que atendam a essa finalidade, mas que não serão explorados. Também não é possível afirmar que os artefatos selecionados são os melhores ou mais eficazes.

\subsubsection{Avaliação de desempenho de fornecedores (Supplier Scorecard)}

Trent (2010) investigou a mensuração de desempenho de fornecedores na cadeia de suprimentos e descobriu que há uma grande carência por sistemas que realizem essa atividade de forma eficaz. O estudo revela que muitas companhias estão insatisfeitas com seu sistema atual de mensuração de desempenho de fornecedores, e parte das empresas sequer possuem um sistema de avaliação de seus fornecedores (TRENT, 2010, p. 24). 
Trent (2010, p. 24) afirma que um sistema de mensuração de desempenho de parceiros da cadeia de suprimentos pode contribuir para o aprimoramento contínuo nas relações da cadeia, e que mesmo as organizações que possuem um sistema maduro de métricas de fornecedores devem reconhecer que a melhoria contínua é um desafio constante.

O estudo apresenta algumas recomendações para implantação de um sistema eficaz de mensuração de desempenho de fornecedores, que poderá conduzir a um processo de melhoria contínua de atividades na cadeia de suprimentos.

Primeiramente, é preciso que o sistema seja flexível o suficiente para capturar a importância de cada fornecedor. Além disso, os clientes internos e os gestores das áreas devem poder avaliar o desempenho dos fornecedores, pois esses indivíduos estão geralmente na melhor posição para avaliar o desempenho operacional dos fornecedores. (TRENT, 2010, p. 25).

Trend (2010) sugere que um relatório sobre o desempenho de cada fornecedor seja enviado para os seus respectivos gestores e, preferencialmente, para mais de um gestor. Caso existam fornecedores que operem em mais de uma região, estes devem ser avaliados de maneira individual, ou seja, por local de atuação. Recomenda também que seja incluída uma métrica de mensuração baseada em custo, porém, adverte que não se deve considerar apenas o custo unitário do produto, mas sim o custo total de fazer negócio com o fornecedor.

Segundo Trent (2010, p. 28), um sistema de mensuração de desempenho deve conter informações atualizadas em tempo real. Para isso é preciso haver integração com os fornecedores, incluindo os sistemas de contas a pagar, controle de qualidade e transporte. $\mathrm{O}$ esforço de mensuração de desempenho deve ser concentrado nos fornecedores críticos.

Trent (2010) recomenda, ainda, que os fornecedores possam ter acesso online aos relatórios de desempenho, e que possam comparar o seu desempenho com o de outros fornecedores. Outra recomendação do autor é incentivar a realização de benchmarking entre fornecedores a fim de que as melhores práticas sejam difundidas na cadeia de suprimentos. Todos esses pontos levantados pelo autor têm objetivo de evitar problemas comuns no sistema de mensuração de desempenho e conduzir a um programa de melhoria continua dos processos. 


\subsubsection{Custeio baseado em atividade (ABC) e gestão baseada em atividade (ABM)}

Wang et al (2010) demonstram como a implementação do ABC/ABM em uma empresa chinesa do setor de alimentos pode trazer diversos benefícios para a gestão de custos e análise de lucratividade de produto, refletindo também na melhoria da gestão da cadeia de suprimentos e redução dos custos logísticos.

A empresa decide utilizar os métodos de custeio baseado em atividade ( $A B C)$ e de gestão baseada em atividade (ABM) para fortalecer a gestão logística em sua cadeia de valor e a gestão das informações de custos, visando aumentar sua vantagem competitiva. (WANG et al, 2010, 39).

O estudo foi conduzido em oito etapas. Na primeira fase, realizou-se análise da demonstração do resultado e identificaram-se os principais custos logísticos da empresa. Na segunda etapa, foram selecionados dois produtos e aplicado o método tradicional de custeio baseado em volume de vendas como principal cost driver.

A terceira etapa consistiu em identificar as principais atividades relacionadas ao processo logístico, encontram sete atividades: (1) processar ordens dos clientes; (2) armazenar, (3) comprar matéria prima; (4) inspecionar; (5) processar pedidos; (6) carregar pedidos; (7) distribuir.

$\mathrm{Na}$ quarta etapa, foram identificados os recursos necessários para executar cada uma das atividades. Na etapa cinco, foram calculadas as taxas de utilização de recursos de cada atividade. Na etapa seis, foram calculados os custos logísticos utilizando o método ABC. Na sétima etapa, foram comparados os custos alocados utilizando o método de custeio tradicional e o ABC. Descobriu-se que o método tradicional estava superestimando os custos de um produto e subestimando o de outro.

A etapa oito consistiu em analisar a lucratividade por produto e permitiu, ainda, uma análise de Pareto para verificar qual atividade tem custo mais representativo. Verificou-se que os gastos com distribuição e armazenagem representavam mais de 84\% dos custos logísticos, portanto, os esforços para redução de custos deveriam concentrar-se nessas atividades, visando eliminar processos que não agregam valor. 
A implementação do $\mathrm{ABC} / \mathrm{ABM}$ contribuiu para que muitas soluções para reduzir custos logísticos e melhorar a eficiência de atividades na cadeia de suprimentos fossem encontradas. WANG et al $(2010,39)$ afirmam que técnicas de gestão estratégica de custos como ABC e $\mathrm{ABM}$ aplicada aos custos logísticos trazem benefícios imediatos à empresa. No ano seguinte à implementação do $\mathrm{ABC} / \mathrm{ABM}$ as receitas da empresa investigada haviam aumentado em $4 \%$ porém os custos logísticos foram reduzidos em $2 \%$.

Comellia et al (2008) também investigaram os benefícios o $\mathrm{ABC}$ na gestão da cadeia de suprimentos e constataram que ele aumenta a visibilidade dos custos, além de contribuir para o processo de avaliação do planejamento da produção.

\subsubsection{Plano de negócio integrado na gestão logística}

O artigo de Muzumdar e Viswanathan (2009) aborda o tema Plano de Negócios Integrado (PNI) e foi desenvolvido a partir dos resultados de uma pesquisa conduzida pela consultoria Alberdeen Group. Na visão dos autores, este tema vem se tornando indispensável devido à velocidade das mudanças na maneira de se fazer negócio e à recente crise financeira mundial. O PNI, além de envolver trocas de informação entre parceiros de uma cadeia de suprimentos, é uma ferramenta de gestão operacional (abordagem tradicional) e estratégica (MUZUMDAR; VISWANATHAN, 2009, p. 34).

A beleza da abordagem do plano de negócio integrado é que pode ser adotado a qualquer tempo no ciclo de vida da organização - durante recessão ou expansão. (MUZUMDAR; VISWANATHAN, 2009, p. 36). Importante destacar que a abordagem do ciclo de vida organizacional descrita pelos autores diz respeito à situação atual da empresa em termos de crescimento e recessão, diferente, portanto, da abordagem empregada nesta dissertação.

Para o sucesso do PNI alguns elementos precisam estar presentes. Primeiramente é preciso haver integração entre o planejamento financeiro e operacional. $\mathrm{O}$ modelo financeiro deve considerar impactos no capital de giro, lucros, fluxo de caixa e outros indicadores financeiros e, finalmente, integrar a gestão de produtos ao PNI (MUZUMDAR; VISWANATHAN, 2009, p. 37). 
Na pesquisa conduzida pelo Aberdeen Group apenas 20\% das empresas destacaram-se e foram classificadas como "best-in-class companies". Foram utilizados os seguintes critérios de mensuração: nível de serviço (pontualidade e correção na entrega de pedidos), ciclo financeiro médio (transformar as receitas em caixa), retorno sobre os ativos, e margem de lucro.

Muzumdar e Viswanathan (2009) indicam três passos para uma organização tornar-se "bestin-class company". O primeiro é investir na capacitação dos gestores. Uma gestão eficaz da capacidade de reação da cadeia de suprimentos reduz o tempo para realizar as atividades e as suas variações, diminui a necessidade de investimento em estoque, aumenta a satisfação dos clientes e as receitas e, contribui para eliminar custos na cadeia de suprimentos. (MUZUMDAR; VISWANATHAN, 2009, p. 39).

O segundo passo está relacionado ao desenvolvimento de habilidades para realizar a gestão de cenários detalhada, contendo simulações e otimizações. Apenas $23 \%$ das empresas apontadas como "best-in-class" possuem uma habilidade forte para criar oportunidades de avaliações lucrativas a partir da análise do PNI. (MUZUMDAR; VISWANATHAN, 2009, p. 39).

A terceira recomendação consiste em se tornar proficiente em entender a raiz dos problemas. Essa é uma área em que até mesmo as companhias "best-in-class" concentram esforços. Soluções de análises de PNI podem ajudar as companhias a desenvolver a análise na raiz dos problemas e tomar as ações corretivas necessárias. (MUZUMDAR; VISWANATHAN, 2009, p. 40).

\subsubsection{Gestão de custos interorganizacional}

Gestão de custos interorganizacional (GCI) é uma abordagem voltada para o gerenciamento de custos através de ações cooperativas entre empresas de uma cadeia de suprimentos (COOPER; SLAGMULDER, 2003a, p. 14). Contudo, a GCI não é um artefato que visa somente reduzir custos, mas também fortalecer relacionamentos entre parceiros, além de aumentar a eficiência da cadeia.

Segundo Souza e Rocha (2009, p. 25) o objetivo principal da GCI é encontrar soluções de gerenciamento de custos que façam com que o retorno total da cadeia (ou de uma parte dela) 
seja garantido ou aumentado. Se toda cadeia puder ser mais eficiente, haverá mais lucro a ser compartilhado por seus integrantes, portanto, a GCI é uma maneira de a cadeia de suprimentos aumentar a sua lucratividade total. (COOPER; SLAGMULDER, 2003a, p. 14).

A eliminação de alguns custos de transação pode melhorar o relacionamento da cadeia e existem quatro caminhos possíveis: (1) Algumas atividades podem ser eliminadas; (2) Alguns processos podem ser simplificados; (3) Atividades e processos podem ser padronizados; e (4) Atividades podem ser automatizadas (COOPER; SLAGMULDER, 2003a, p. 17).

Existem três aspectos principais da gestão de custos interorganizacional: (1) melhora o desenho do produto; (2) melhora a eficiência do processo de produção; e (3) aumenta a eficiência no relacionamento entre comprador e vendedor. No entanto, esses benefícios serão atingidos somente se houver compartilhamento dos ganhos entre os parceiros envolvidos (COOPER; SLAGMULDER, 2003b, p. 12).

Como a GCI é um artefato de controle gerencial que envolve mais de um integrante de uma cadeia de suprimentos um dos propósitos do presente estudo é verificar se há relação entre a utilização desse artefato e os estágios de MGL e CVO.

\subsubsection{Custeio alvo}

Cooper e Slagmulder (2003b) sugerem outro artefato de controle gerencial pode ocorrer concomitantemente à GCI: o Custeio alvo. A aplicação do Custeio alvo em cadeia de suprimentos ocorre quando a saída do sistema de custeio alvo do comprador torna-se entrada no sistema de custeio alvo do fornecedor. (COOPER; SLAGMULDER, 2003b, p. 12).

Para Ansari et al (2007, p. 507), o custeio alvo é um sistema de planejamento de lucro e de gestão de custos que garante que os novos produtos e serviços atendam aos preços e retornos determinados pelo mercado. Entretanto, Cooper e Slagmulder (2003b, p.14) lembram que a natureza da determinação do custo alvo (consequentemente do preço e do retorno) se desenha, predominantemente, por meio da relação de poder entre as entidades envolvidas na cadeia de suprimento. Ou seja, um comprador com muito poder de barganha pode determinar o preço de venda do fornecedor com menor poder. 
Blocher et al (2010, p. 12) explicam que as empresas que utilizam o Custeio alvo geralmente adotam medidas para a redução de custos ou realizam ajustes que podem ser tanto no projeto dos produtos quanto no processo de produção. Este é um método que força as empresas a manterem-se competitivas.

\subsubsection{Análise do custo para servir.}

Braithwaite e Samakh (1998) realizaram um estudo de caso com uma empresa europeia do setor eletrônico para demonstrar os benefícios da utilização do método de análise do custo para servir (Cost-to-Serve method). Essa ferramenta de controle gerencial pode fornecer informações que facilitam a integração da cadeia de valor, diferentemente dos métodos de acumulação de custo tradicionais, baseados em funções. Braithwaite e Samakh (1998, p. 70) que a experiência tem mostrado que a análise do custo para servir é o um direcionador de mudanças.

Os autores relacionam os principais problemas para a gestão da cadeia de suprimentos:

- Variedade de custos: Cada produto dentro de um portfólio contribui de maneira particular para a formação do lucro da empresa.

- Gestão da cadeia de clientes: Toda empresa possui grandes e pequenos clientes e as diferenças que surgem após a análise do custo para servir podem ser bastante significativas.

- Objetivos do serviço ao cliente: A natureza dos compromissos que a empresa assume com seus clientes define o seu posicionamento no mercado e é fundamental para definir a estratégia e estrutura da cadeia de suprimentos.

- Mapa da cadeia de suprimentos e estrutura de relacionamentos: O mapa da cadeia de suprimentos é ajustado às características das ordens, dos compromissos assumidos com os clientes e da disponibilidade dos produtos, como consequência é preciso desenvolver formas de compartilhar recursos.

- Políticas comerciais e de preços: A política de preços e os termos determinados pelas empresas refletem a sua visão sobre as oportunidades e seu posicionamento competitivo. As empresas devem possuir propostas de integração em seu posicionamento e foco na cadeia de suprimentos. 
- Ênfase no custeio por funções e na recompensa pessoal. A ênfase em funções reforça a arquitetura da empresa e representa uma barreira às mudanças na cadeia de suprimentos. Por outro lado, a ênfase na cadeia de suprimentos (supply chain thinking) fornece subsídios para introdução de novas ideias.

A empresa que foi objeto do estudo, denominada pelos autores de Hi-tech, possui quatro famílias de produtos (monitores, processadores, periféricos e acessórios) e quatro canais de distribuição (distribuidores, grandes clientes, varejo e OEM's - original equipments manufactures). Para entender como os diferentes segmentos afetavam o resultado da empresa, os autores realizaram uma análise detalhada dos custos de cada família de produto e de cada canal de distribuição. Entretanto, recomendam que a análise não seja muito complexa, uma vez que modelos com muitos detalhes não traz conclusões mais sofisticadas, quanto mais simples e rápido melhor (BRAITHWAITE; SAMAKH, 1998, p. 73).

Os resultados da análise do custo para servir da empresa Hi-tech demonstraram haver grande dispersão entre os custos por canais de distribuição, famílias de produtos (processadores e monitores. Demonstraram ainda qual a contribuição para a margem bruta dos diferentes canais de distribuição e famílias de produtos.

De posse de todas essas informações conseguidas através da introdução de um modelo de custo para servir, a empresa pôde tomar diversas providências a fim de impactar positivamente o seu resultado. Dentre as possíveis decisões destacam-se: melhorias de curto prazo, decisões de investimentos; decisões de suprimentos e mudanças nos termos comerciais.

No Brasil, Guerreiro et al (2008) realizaram estudo de caso com uma empresa de alimentos e constataram que a mensuração do custo para servir os clientes também pode fornecer informações importante e detalhada sobre a análise de lucratividade por cliente.

\subsubsection{Análise do custo total na gestão logística}

Lambert e Burduroglu (2000, p. 6) definem a análise do custo total como busca por alternativas para minimizar o custo logístico total, incluindo transporte, armazenagem, estocagem, sistema de informação e processamento de ordens, compras e custos relacionados à produção, dentro do nível de serviço exigido pelo cliente. Bowersox et al (2010, p. 317) 
complementam, afirmando que a identificação da estrutura de custo total mínimo é o objetivo da integração logística.

Faria e Costa (2008, p. 45) argumentam, ainda, que o conceito do custo logístico total é a premissa que sustenta as análises dos custos de todo o macroprocesso logístico, auxiliando o gestor na tomada de decisão. Na perspectiva de Lambert e Burduroglu (2010), a análise do custo logístico total é utilizada para mensurar o potencial que a atividade logística tem de criar valor através da redução de custos.

Os autores demonstram que a análise de custo logístico total pode ser utilizada para comparar a eficiência logística de uma empresa com a de seus concorrentes. Entretanto, a análise de custo logístico total também pode ser utilizada para outras decisões estratégicas, como a escolha entre tipos de modais de transporte ou decisões sobre a quantidade e localização das instalações de plantas (BOWERSOX et al, 2010, p. 317).

Lambert e Burduroglu (2010, p. 7) lembram que, devido à natureza complexa (interrelacionada) do processo logístico, é preciso considerar que a redução de custo em uma atividade específica pode resultar em aumento em outra ponta do processo. Bowersox et al (2010, p. 317) reforçam essa visão, afirmando que é muito difícil identificar e mensurar todos os aspectos do custo logístico total. Para realizar tal análise, é preciso fazer um desenho completo da rede logística e assumir algumas premissas.

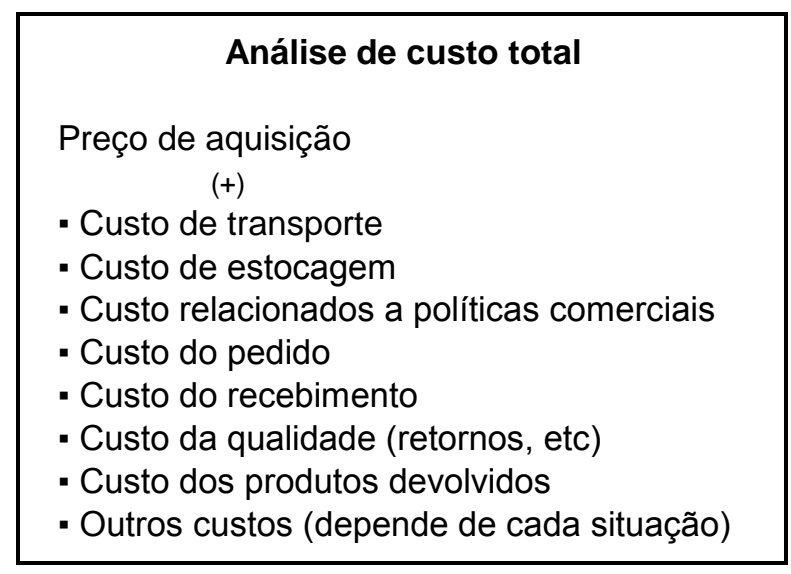

Ilustração 2: Modelo de análise de custo logístico total Fonte: Lambert e Burduroglu (2010, p. 7). 
Lambert e Burduroglu (2010, p. 7) apresentam um possível modelo para análise de custo logístico total que parte do custo de aquisição do produto ou serviço e inclui outros custos logísticos relacionados à propriedade do produto, conforme Ilustração 2. Embora seja um artefato importante para decisões logísticas, Mendel (2009) constatou que as empresas brasileiras não o estão utilizando de forma extensiva.

\subsection{Formulação das hipóteses de pesquisa}

Após a apresentação das características dos dois modelos teóricos (MGL e CVO) e dos artefatos de controle gerencial, duas hipóteses principais foram formuladas. A primeira hipótese baseia-se nas similaridades de descrições entre os estágios dos modelos. Dessa forma acredita-se na existência de uma associação não aleatória entre os estágios de maturidades da gestão logística e do ciclo de vida organizacional:

H1: Existe associação não aleatória entre os estágios de maturidade da gestão logística (MGL) e estágios do ciclo de vida organizacional (CVO).

Com base na primeira hipótese, foram formuladas hipóteses de associações específicas, indicando quais os estágios em que se espera encontrar tal relação, de acordo com a revisão da literatura.

No estágio mais simples do modelo de maturidade da gestão logística (MGL), denominado Fundação, há o predomínio de estrutura horizontal, os processos são mal definidos e há concentração do poder. Tais características encontram algumas similaridades com a descrição do estágio Existência, de acordo com a teoria do CVO, levando à formulação da primeira hipótese específica:

H1 $1_{\mathrm{A}}$ : Empresas classificadas como Fundação no modelo de MGL serão classificadas como Existência no modelo de CVO.

No próximo estágio do modelo de MGL, denominado Estrutura, a principal característica é a organização dos processos e há algum nível de delegação de autoridade, embora a estrutura 
continue funcional, Nesse aspecto existem similaridades com as características do estágio Sobrevivência, do CVO, levando à segunda hipótese específica:

H1 : Empresas classificadas como Estrutura no modelo de MGL serão classificadas como Sobrevivência no modelo de CVO.

No terceiro e quarto estágios do modelo de MGL, Visão e Integração, respectivamente, o foco da gestão logística é estabelecer a integração interna e externa entre as áreas da empresa e entre os parceiros da cadeia, através da amarração do fluxo de informação. O papel do sistema de informação é crucial em ambos os estágios. Além disso, há maior delegação de responsabilidades e pode haver estruturas não funcionais para controlar os processos. Tais características encontram maior similaridade com o terceiro estágio do CVO, Sucesso, que é marcado pela formalização dos processos e proteção das fontes de vantagem competitiva. Assim, formulou-se a terceira hipótese específica:

H1 : Empresas classificadas como Visão ou Integração no modelo de MGL serão classificadas como Sucesso no modelo de CVO.

No estágio Dinâmico do modelo de MGL, as principais características são a possibilidade de formação de equipes multifuncionais (estrutura matricial) orientadas a processos, a colaboração entre empresas da cadeia de suprimentos e a busca de parcerias estratégicas com essas empresas, levando à consolidação de vantagens competitivas. Tais características encontram maior similaridade com o estágio Reativação do CVO, em que o foco é a retomada do crescimento. Dessa forma, formulou-se a quarta hipótese específica:

H1 D: Empresas classificadas como Dinâmica no modelo de MGL serão classificadas como Reativação no modelo de CVO.

Por falta de uma maior similaridade na caracterização das empresas que se encontram no estágio de Declínio do modelo de CVO, já que o declínio pode ocorrer em qualquer estágio após o nascimento e não há uma idade ou tamanho característico (MILLER E FRIESSEN, 1984, p. 1178), não foi formulada hipótese específica que o relacione com qualquer estágio do modelo de MGL. 
A revisão da literatura também permitiu a identificação de diversos benefícios à gestão logística, gerados a partir da implantação e utilização de artefatos de controle gerencial como o supplier scorecard, ABC e ABM, plano de negócio integrado, gestão de custos interorganizacionais e custeio alvo, análise de custo para servir e análise do custo total.

Tal constatação sugere que, quanto mais artefatos de controle gerencial utilizado pela empresa mais avançado é o estágio de MGL e do CVO. Dessa forma, formulou-se a segunda hipótese de pesquisa:

H2: Empresas classificadas em estágios mais avançados do modelo de MGL e do CVO utilizam maior quantidade de artefatos de controle gerencial.

As primeiras hipóteses (principal e específicas) foram testadas com utilização da técnica ANACOR - Análise de Correspondência. A segunda hipótese foi testada através de média de utilização de artefato por estágios e teste de Qui-quadrado. As técnicas metodológicas estão descritas no próximo capítulo. A formulação de todas as hipóteses de pesquisas foi apoiada na revisão da literatura sobre os dois modelos teóricos, bem como sobre utilização de artefatos de controle gerenciais. Os conceitos teóricos serão retomados no capítulo 4 para análise dos resultados. 


\section{PROCEDIMENTOS METODOLÓGICOS}

"A busca por associação entre variáveis é frequentemente um dos propósitos das pesquisas empíricas" (MARTINS, 2001). Como estratégia de pesquisa, este trabalho enquadra-se na modalidade teórico-empírico. Castro (1978) afirma que esse é o tipo metodológico mais indicado para uma tese de pós-graduação.

A pesquisa mensurou o estágio atual de maturidade da gestão logística e do ciclo de vida das empresas com base na percepção de seus gestores. O instrumento de coleta de dados foi o questionário (survey). Segundo Martins e Theóphilo (2009, p. 93), essa técnica “consiste de perguntas a respeito de variáveis que se pretende medir ou descrever", sendo que este é um instrumento de coleta importante e popular no campo das Ciências Sociais. Por meio de questionários o pesquisador pode medir ou inferir sobre variáveis que não poderiam ser diretamente observadas, por isso sua importância para o avanço da pesquisa nesse campo.

A construção do questionário demandou uma reflexão sobre a dinâmica de causalidade entre as variáveis estudadas e, principalmente, assegurou-se que o instrumento de coleta estava apoiado em uma plataforma teórica consistente. De maneira simplificada, teoria pode ser entendida como "[...] um conjunto de construtos, conceitos e definições que se relacionam entre si” (MARTINS; THEÓPHILO, 2009, p. 28).

Quanto à reflexão sobre a dinâmica de causalidade, Martins e Theóphilo (2009, p. 10), explicam que "a noção estrita de causalidade tem sido considerada inadequada para o estudo dos fenômenos sociais, devido ao grande número e à complexidade das variáveis que os envolvem”. Por isso, buscou-se modelos mais flexíveis para entender essas relações.

Devido à complexidade dos construtos, não é possível inferir com segurança sobre a dinâmica de causalidade, tampouco este foi o objetivo desta pesquisa. Portanto, definiu-se que os grupos de variáveis que estão envolvidas neste estudo apresentam uma dinâmica de causalidade do tipo recíproca, na qual as variáveis se influenciam mutuamente (ROSEMBERG, 1976 apud MARTINS; THEÓPHILO, 2009, p. 11), ou seja, considerou-se que os estágios do CVO e de MGL influenciam-se reciprocamente. 
Embora existam técnicas multivariadas capaz de esclarecer essas relações de causalidade recíproca, como, por exemplo, a modelagem de equações estruturais, que têm sido utilizadas em diversas áreas de pesquisa para tentar resolver problemas de relações de dependências inter-relacionadas e simultânea (HAIR et al, 2005, p. 466), este não é o foco desta dissertação.

Quanto à plataforma teórica, este estudo está apoiado em dois modelos teóricos: o de Maturidade da gestão logística e o de Ciclo de vida organizacional. Seus conceitos fundamentais foram apresentados no Referencial Teórico. Contudo, o instrumento de coleta não deve apenas estar apoiado em uma teoria consistente. É necessário, todavia, abordar aspectos relacionados à sua validade e confiabilidade. Segundo Martins e Theóphilo (2009, p. 12), confiabilidade é a constância dos resultados obtidos quando aplicados ao mesmo grupo de indivíduos e a validade é a capacidade do instrumento de medir o que se propõe a medir.

O principal indicador de confiabilidade do instrumento de coleta é o Alfa de Cronbach, que consiste na medição do grau de correlação entre o escore individual de cada item do questionário com o escore total dos demais itens (MARTINS; THEÓPHILO, 2009, p. 12). Já para os indicadores de validade, o instrumento apoia-se na validade aparente (julgada pela banca examinadora), validade de conteúdo (apoiada em estudos anteriores) e validade de construto (apoiada nos modelos conceituais descritos no capítulo dois).

\subsection{Instrumento de coleta - Estrutura do formulário}

O instrumento de coleta foi operacionalizado através de um formulário eletrônico comercializado pela empresa Vroman Systems Inc (Form site). Teve o objetivo de mensurar as percepções dos respondentes sobre a situação atual da empresa onde atuam com relação a todos os construtos dos dois modelos teóricos, bem como obter informações sobre a utilização de determinados artefatos de controle gerencial.

O formulário teve cinco partes. A primeira consistiu de um texto com um termo de compromisso e de confidencialidade, bem como uma explicação sobre o objetivo da pesquisa, conforme Apêndice 1. A segunda consistiu de perguntas visando identificar o respondente e traçar um perfil da empresa em termos de idade, porte, área de atuação e posição do respondente na empresa, conforme apêndice 2 . 
A terceira parte do formulário foi dedicada ao questionário sobre a gestão logística (Apêndice 4). Na quarta, encontram-se as questões relacionadas ao ciclo de vida da organização (Apêndice 6). Finalmente, na parte cinco, estão as perguntas dicotômicas, do tipo sim ou não, sobre a utilização de artefatos de controle gerencial pela empresa (Apêndice 7).

Para classificar o estágio de maturidade da gestão logística dessas mesmas empresas, foi utilizada uma versão adaptada do questionário de 90 questões de Oliveira (2009). Já para classificar as empresas quanto ao estágio do ciclo de vida organizacional foi utilizado o questionário de Lester et al (2003).

No que se refere às questões sobre a gestão logística, vinte e cinco afirmações que abordavam pontos importantes dos treze construtos identificados no modelo de Oliveira (2009) foram propostos. Solicitou-se aos respondentes que atribuíssem seu grau de concordância, em uma escala de um a cinco pontos, quanto à aplicação de cada ponto na sua empresa sendo que um significava discordo totalmente e cinco, concordo totalmente. O item 3.1.1 fornece maiores detalhes sobre o processo de classificação das empresas nos estágios do modelo.

Já para classificar o estágio atual do ciclo de vida organizacional, o formulário continha apenas cinco perguntas que abordam os construtos desse modelo, que são: ambiente, modelo de decisão, estrutura organizacional, processamento de informação e distribuição de poder na empresa. Para cada questão existem de três a cinco situações descritas, sendo que cada situação corresponde a determinado estágio do ciclo de vida, e o respondente deve assinalar aquela que mais se aproxima da realidade de sua empresa. O tratamento utilizado para classificar as empresas nos estágios de CVO é abordado no item 3.1.2.

\subsubsection{Construção do formulário}

Para construção do instrumento de coleta foram necessários alguns tratamentos e adaptações dos questionários originais, tanto para aplicação do modelo de ciclo de vida organizacional, quanto para o modelo de maturidade da gestão logística, conforme descrito a seguir.

O questionário original do modelo de CVO está em inglês, conforme pode ser observado no Anexo A. Portanto, a primeira tarefa foi traduzi-lo para o português. Como forma de tentar 
reduzir o viés na tradução, utilizou-se o método de comparação, ou seja, o questionário original foi traduzido por quatro pesquisadores diferentes e os textos traduzidos foram comparados. As diferenças foram discutidas e analisadas até se chegar a um modelo final para o questionário de CVO, conforme demonstra o Apêndice 6.

Já o questionário sobre maturidade da gestão da cadeia de suprimentos está disponível em português na tese de Oliveira (2009). No entanto, esse questionário é bastante extenso e contém 90 questões, conforme Anexo B. Oliveira (2009) aplicou o questionário e realizou análise fatorial. Com esse procedimento foram identificados 13 construtos.

Para facilitar a operacionalização do questionário de MGL na presente pesquisa, decidiu-se reduzir o número de questões para capturar apenas a essência de cada construto. Dessa forma, respeitando-se a relação de precedência entre construtos, desenvolvida na tese de Oliveira (2009), foi elaborada uma estratégia para reduzir o questionário.

A estratégia consistiu em extrair uma questão para cada construto e uma para mensurar a relação entre construtos, totalizando 25 questões. O modelo para formulação dessas questões é demonstrado no Apêndice 3 e o questionário adaptado, pode ser observado no Apêndice 4.

Como forma de verificar possíveis diferenças na classificação de estágios por utilizar um questionário reduzido ao invés do questionário completo, solicitou-se aos participantes da pesquisa que respondessem o questionário original com 90 questões. Trinta e cinco participantes (16\% da amostra) aceitaram responder o questionário completo, permitindo a comparação da classificação do estágio de MGL pelo questionário original com a do reduzido. Verificou-se não haver diferenças estatísticas significativas no método de classificação dos estágios de MGL em razão da utilização do questionário reduzido, conforme observado no Quadro 1.

Quadro 1 - Teste de Mann-Whitney para diferença de classificação de estágios de MGL

\begin{tabular}{|c|c|}
\hline \multicolumn{1}{|c|}{ Teste } & Sig. \\
\hline Mann-Whitney & 0,572 \\
\hline
\end{tabular}

Finalmente, para construção das questões relacionadas à utilização de artefatos de controle gerencial aplicados à gestão logística, buscou-se resumir os conceitos apresentados no 
Referencial Teórico, a fim de que as questões que fossem simples e diretas. Uma vez que um questionário muito extenso poderia desestimular o respondente.

Solicitou-se aos indivíduos que assinalassem "Sim", caso o artefato fosse utilizado na gestão logística de sua empresa, e "Não", caso contrário. O questionário sobre a utilização de artefatos pode ser observado no Apêndice 7.

\subsection{Público alvo, tamanho da amostra e recebimento das respostas}

Os respondentes são profissionais com atuação em gestão logística e da cadeia de suprimentos e outras áreas relacionadas. O acesso a esses profissionais foi realizado através de quatro fontes principais: (i) base de dados do Logicon - Centro de Pesquisa em Logística Integrada à Controladoria e Negócios; (ii) LikedIn, web site de relacionamento profissional; (iii) base de dados da Revista Mundo Logística, da Editora Mundo; e (iv) base de dados do Portal Supply Chain, da consultoria Ciclo Desenvolvimento.

Antes de o questionário definitivo ser aplicado, foi realizado um pré-teste, a fim de se avaliar compreensão do formulário, redação das questões e tempo necessário para respondê-las. Essa fase contou com a participação de um grupo de cinco profissionais, que forneceram uma avaliação para que o instrumento de coleta fosse ajustado. As respostas da fase de pré-teste foram descartadas para o trabalho final, uma vez que houve uma mudança na estrutura do questionário com a inclusão das questões relativas à utilização de artefatos de controle gerencial, que não estava previsto no período em que foi realizado o pré-teste.

Uma vez definido o público alvo e a estrutura do questionário, o passo seguinte foi determinar o tamanho da amostra. Segundo Doane e Seward (2008, p. 327), o método mais comum para atender a essa finalidade, quando se desconhece o desvio padrão da população, é a estimação do desvio padrão de uma amostra piloto. Para Webster (2007, p. 180), essa amostra piloto de conter, no mínimo, de 30 elementos.

Fávero et al (2009, p. 101), baseando-se em Martins (2005), apresentam o cálculo para determinar o tamanho da amostra (Equação 1), e explicam que $\mathrm{Zg}$ é a abscissa da distribuição normal padrão, $\sigma$ é o desvio padrão da amostra e $\varepsilon$ representa o erro amostral. Webster (2007, 
p. 179) afirma que o erro padrão dessa equação representa o quanto o pesquisador está disposto a tolerar de diferença entre a média populacional e a média amostral.

$$
n=\llbracket \frac{Z_{g \cdot \sigma}}{\varepsilon} \rrbracket^{2}
$$

\section{Equação 1 - Cálculo do tamanho da amostra}

Nesta dissertação, o cálculo do tamanho da amostra foi realizado na segunda semana após o início da coleta, com 52 elementos. Para determinar o valor da abscissa da distribuição normal padrão, foi estabelecido que a média amostral não deveria se afastar da média populacional mais do que 5\%, com probabilidade de 95\%, assim, foi encontrado um valor Zg igual a 1,64. O desvio padrão amostral foi igual a 20,26. Por fim, o erro tolerado para um intervalo igual a 100 (escores podem variar entre 25 e 125) foi de 2,5. Substituindo esses valores na equação 1 , foi determinado o tamanho mínimo da amostra de 177 respondentes.

O período de coleta dos dados foi de sete semanas: de 14/03/2011 a 30/04/2011. Durante essa fase foram, recebidas 228 respostas, porém, como a intenção era avaliar um respondente por organização, houve nove eliminações por duplicidade de empresa. Sete respostas foram recebidas após o período de coleta dos dados e também foram eliminadas. A amostra final, portanto, compreendeu 213 empresas, superior ao tamanho mínimo determinado.

Durante a fase de coleta de dados, houve períodos de recebimento mais elevado, com destaque para a primeira, terceira e sétima semanas, em razão de envio massivo de e-mails através de mala direta da base LOGICON, Revista Mundo Logística e Portal Supply Chain, respectivamente. Por outro lado, houve baixo índice de respostas na sexta semana por conta dos feriados do final de abril.

Cabe destacar também que durante todo o período foram recebidos formulários de contatos identificados via Linkedin. O Gráfico 1 ilustra a distribuição das respostas recebidas ao longo do período de coleta. 


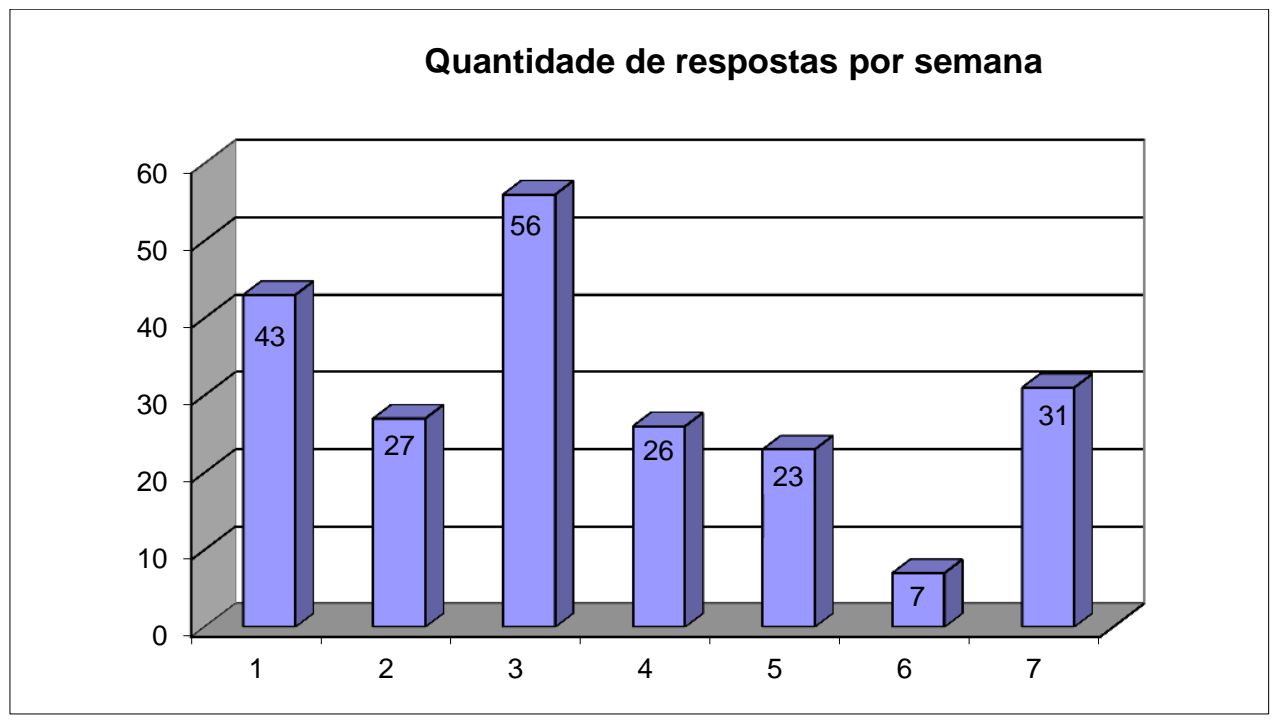

Gráfico 1 - Distribuição das respostas recebidas por semana

Levando em consideração que essas 213 respostas foram recebidas de pelo menos quatro fontes diferentes, houve o cuidado de testar se o padrão de respostas divergia de acordo com a fonte de dados. Para isso, realizou-se um teste de média de escores das respostas, entre os grupos identificados. Como não houve acesso direto do pesquisador às bases da Revista Mundo Logística e do Portal Supply Chain, só foi possível identificar as respostas recebidas por meio de contato realizado pelo Linkedin e Logicon. Dessa forma, quando não foi possível identificar a origem do contato, a resposta foi classificada no grupo N/I (não identificado). A tabela 1 demonstra a quantidade de respostas por grupo de origem.

Tabela 1 - Distribuição de respondentes por grupo de origem

\begin{tabular}{|l|r|r|r|r|r|r|}
\hline \multirow{2}{*}{} & \multicolumn{6}{|c|}{ Casos } \\
\cline { 2 - 7 } Origem & \multicolumn{2}{|c|}{ Válidos } & \multicolumn{2}{c|}{ Faltando } & \multicolumn{2}{c|}{ Total } \\
\cline { 2 - 7 } & $\mathrm{N}$ & Percentual & $\mathrm{N}$ & Percentual & $\mathrm{N}$ & Percentual \\
\hline LINKEDIN & 49 & $100,0 \%$ & 0 &, $0 \%$ & 49 & $100,0 \%$ \\
LOGICON & 34 & $100,0 \%$ & 0 &, $0 \%$ & 34 & $100,0 \%$ \\
N / I & 130 & $100,0 \%$ & 0 &, $0 \%$ & 130 & $100,0 \%$ \\
\hline Total & $\mathbf{2 1 3}$ & & & & & \\
\hline
\end{tabular}

Antes de selecionar o teste estatístico mais adequado para verificar a média desses grupos, foram testados alguns parâmetros. Maroco (2007) explica que os testes paramétricos requerem a observação de alguns parâmetros, que são, basicamente, a normalidade na distribuição das amostras e a homogeneidade das variâncias. 
Um teste para verificar se as variâncias são homogêneas é o de Levene. Fávero et al (2009, p. 117) explicam que, no teste de homogeneidade das variâncias de Levene, a hipótese nula afirma que as variâncias são homogêneas. $O$ resultado para este teste apresentou significância de 40,1\%, conforme o Quadro 2. Portanto, ao nível de significância de 5\%, há evidências estatísticas para afirmar que a variâncias dos três grupos de respondentes são homogêneas.

\section{Quadro 2 - Resultado do teste de homogeneidade das variâncias}

\begin{tabular}{|r|l|}
\hline Estatística Levene & Sig. \\
\hline, 918 &, 401 \\
\hline
\end{tabular}

Para testar a normalidade, Fávero et al (2009, p. 115) indicam o teste de KolmogorovSminorv, e explicam que a hipótese nula do teste é de que a amostra provém de uma distribuição normal. O teste foi realizado e observou-se normalidade na distribuição das respostas dos grupos Linkedin e LOGICON, porém não foi observado para o grupo N/I (Sig. $<5 \%$ ), conforme se pode observar no Quadro 3. Dessa forma, não há evidências para aceitar a hipótese nula e também não são atendidos os pré-requisitos para a utilização de testes paramétricos.

\section{Quadro 3 - Resultado teste de normalidade da distribuição}

\begin{tabular}{|l|r|c|}
\hline \multirow{2}{*}{ Origem } & \multicolumn{2}{|c|}{ Kolmogorov-Smirnov } \\
\cline { 2 - 3 } & Estatística & Sig. \\
\hline LINKEDIN &, 091 &, $200^{*}$ \\
LOGICON &, 085 &, $200^{*}$ \\
N / I &, 080 &, 041 \\
\hline
\end{tabular}

O teste não paramétrico mais adequado para testar a diferença de médias de $k$ amostras $(\mathrm{K}>2)$ é o teste de Kruskal-Wallis (FÁVERO et al, 2009, p. 176). Nesse teste, a hipótese nula é que a distribuição das $k$ amostras provém de uma mesma população. O resultado do teste está demonstrado no Quadro 4. Como o nível de significância foi de 87,7\%, há evidências estatísticas para aceitar a hipótese nula, com nível de confiança de 95\%, de que os três grupos provêm de uma mesma população, ou seja, não há diferenças relevantes no padrão de respostas quanto à sua origem.

Quadro 4 - Resultado teste Kruskal-Wallis

\begin{tabular}{|l|r|}
\hline & Escore \\
\hline Qui-quadrado &, 263 \\
Sig. &, 877 \\
\hline
\end{tabular}


Finalmente, foi testada a confiabilidade das respostas recebidas. Para Martins e Theóphilo (2009, p. 13) "a confiabilidade refere-se à consistência ou estabilidade de uma medida". Para medir a consistência interna das respostas utilizou-se o coeficiente alfa de Cronbach.

Quando o coeficiente do teste for superior a 70\%, diz-se que há confiabilidade das medidas (MARTINS; THEÓPHILO, 2009, p. 15). Conforme demonstra o Quadro 5, o teste realizado nas 25 questões do modelo de maturidade de gestão logística resultou em um coeficiente de 94.6\%, demonstrando que há consistência interna nas respostas recebidas.

\section{Quadro 5 - Teste de confiabilidade das respostas recebidas}

\begin{tabular}{|r|r|}
\hline Alfa de Cronbach & № de Itens \\
\hline, 946 & 25 \\
\hline
\end{tabular}

\subsection{Análise dos dados}

Os dados recebidos foram trabalhados em duas etapas: a primeira compreendeu a análise do perfil das empresas e respondentes, a classificação do estágio atual de MGL e CVO das empresas; e a determinação da quantidade média de artefatos de controle gerencial utilizados; a segunda consistiu na verificação de existência de associação entre os estágios dos dois modelos teóricos, bem como a verificação das relações entre a utilização de artefatos de controle gerencial com os estágios de desenvolvimento de MGL e CVO.

\subsubsection{Classificação das empresas nos estágios de maturidade da gestão logística}

Para a classificação do estágio atual de maturidade da gestão da logística das empresas, foi utilizada uma adaptação dos pontos de transição desenvolvida por Oliveira (2009), ou seja, em sua tese o autor utiliza um formulário com noventa questões e identifica os escores que delimitam os estágios de maturidade dentro do intervalo de 90 a 450 pontos (noventa questões em uma escala Likert de um a cinco).

$\mathrm{Na}$ tese de Oliveira (2009), empresas com escore inferior a 203 foram classificadas como Fundação, entre 203 e 257 como Estrutura, entre 258 e 303 como Visão, entre 304 e 354, como Integração e, com escore superior a 354, como Dinâmica. 
Para esta dissertação, realizou-se uma conversão desses pontos de transição, uma vez que o questionário adaptado contém apenas 25 questões, no qual o respondente assinala o seu grau de concordância em uma escala de um a cinco, conforme o Apêndice 4. Portanto, a escala de pontuação do neste trabalho varia entre 25 e 125 pontos, correspondendo a uma redução de 3,6 vezes em cada ponto de transição. As escalas e os pontos de transição (original e adaptado) são demonstrados no Quadro 6.

Quadro 6 - Pontos de transição para os estágios de maturidade do processo logístico

\begin{tabular}{|c|cc|cc|cc|cc|cc|}
\hline & \multicolumn{8}{|c|}{ PONTOS DE TRANSIÇÃO } \\
\hline Estágios & Fundação & Estrutura & Visão & Integração & Dinâmica \\
\hline & Min & Max & Min & Max & Min & Max & Min & Max & Min & Max \\
\hline OLIVEIRA & 90 & 203 & 204 & 257 & 258 & 303 & 304 & 354 & 355 & 450 \\
SOUZA & 25 & 56 & 57 & 71 & 72 & 84 & 85 & 98 & 99 & 125 \\
\hline
\end{tabular}

Dessa forma, as empresa com escore menor do que 56 foram classificadas como Fundação, com escores de 57 a 71, como Estrutura, de 72 a 84, como Visão, de 85 a 98, como Integração e, aquelas com escores maiores do que 98, como Dinâmica.

\subsubsection{Classificação das empresas nos estágios de ciclo de vida}

Para classificar as empresas nos estágios de ciclo de vida organizacional segundo o modelo de Lester et al (2003), o critério foi a análise de respostas por construto teórico. No modelo, existem cinco construtos, para cada um existem de três a cinco afirmações, que corresponde às características de determinado estágio do ciclo de vida, conforme demonstra o Quadro 7. 
Quadro 7 - Relação entre afirmações e estágios do CVO

\begin{tabular}{|c|c|c|}
\hline Construto & Afirmação & Estágio \\
\hline Ambiente & $\begin{array}{l}\text { Nossa empresa é pequena, tanto em tamanho quanto em } \\
\text { comparação com nossos concorrentes. }\end{array}$ & Existência \\
\hline Ambiente & $\begin{array}{l}\text { Como uma empresa, nós somos maiores do que a maioria de } \\
\text { nossos concorrentes, mas não tão grande como poderia ser. }\end{array}$ & Sucesso \\
\hline Ambiente & Somos uma grande empresa, com diretores e acionistas. & Reativação \\
\hline Modelo de decisão & $\begin{array}{l}\text { O processo decisório é centralizado no topo da organização e } \\
\text { não é considerado muito complexo. }\end{array}$ & Declínio \\
\hline Modelo de decisão & $\begin{array}{l}\text { A maioria das decisões da nossa empresa é tomada por um grupo } \\
\text { de gestores que empregam algumas análises sistemáticas, mas } \\
\text { que não são suficientemente ousadas. }\end{array}$ & $\begin{array}{l}\text { Sobrevivênci } \\
\text { a }\end{array}$ \\
\hline Modelo de decisão & $\begin{array}{l}\text { A maioria das decisões da nossa empresa é tomada por gerentes, } \\
\text { força tarefa, e equipes de projetos que tentam promover o } \\
\text { crescimento através da participação. }\end{array}$ & Reativação \\
\hline Estrutura organizacional & $\begin{array}{l}\text { Estrutura organizacional da nossa empresa poderia ser descrita } \\
\text { como simples. }\end{array}$ & Existência \\
\hline Estrutura organizacional & $\begin{array}{l}\text { Nossa estrutura é departamental e funcional e se tornou muito } \\
\text { formal. }\end{array}$ & Sucesso \\
\hline Estrutura organizacional & $\begin{array}{l}\text { A estrutura de trabalho em nossa empresa é divisional ou } \\
\text { matricial, com sistemas de controles altamente sofisticados. }\end{array}$ & Reativação \\
\hline Estrutura organizacional & $\begin{array}{l}\text { Nossa estrutura é centralizada, com apenas alguns sistemas de } \\
\text { controle. }\end{array}$ & Declínio \\
\hline Estrutura organizacional & $\begin{array}{l}\text { Na nossa organização, há certo nível de especialização } \\
\text { (contadores e possivelmente engenheiros, por exemplo) e } \\
\text { estamos de alguma forma nos tornando diferenciados. }\end{array}$ & $\begin{array}{l}\text { Sobrevivênci } \\
\text { a }\end{array}$ \\
\hline $\begin{array}{l}\text { Processamento de } \\
\text { informações }\end{array}$ & $\begin{array}{l}\text { O processamento de informação pode ser mais bem descrito } \\
\text { como sendo simples muitas vezes informal. }\end{array}$ & Existência \\
\hline $\begin{array}{l}\text { Processamento de } \\
\text { informações }\end{array}$ & $\begin{array}{l}\text { O processamento de informações monitora o desempenho e } \\
\text { facilita a comunicação entre os departamentos. }\end{array}$ & $\begin{array}{l}\text { Sobrevivênci } \\
\text { a }\end{array}$ \\
\hline $\begin{array}{l}\text { Processamento de } \\
\text { informações }\end{array}$ & $\begin{array}{l}\text { O processamento de informações é sofisticado e necessário para } \\
\text { gerar uma produção eficiente e lucratividade adequada. }\end{array}$ & Sucesso \\
\hline $\begin{array}{l}\text { Processamento de } \\
\text { informações }\end{array}$ & $\begin{array}{l}\text { O processamento de informação é bastante complexo, utilizado } \\
\text { para coordenar diversas atividades e para melhor servir o } \\
\text { Mercado. }\end{array}$ & Reativação \\
\hline $\begin{array}{l}\text { Processamento de } \\
\text { informações }\end{array}$ & $\begin{array}{l}\text { O processamento de informações não é muito sofisticado, mas } \\
\text { altamente necessário. }\end{array}$ & Declínio \\
\hline $\begin{array}{l}\text { Processamento de } \\
\text { informações }\end{array}$ & $\begin{array}{l}\text { O processamento de informações não é utilizado da maneira } \\
\text { plena }\end{array}$ & Declínio \\
\hline Distribuição de poder & $\begin{array}{l}\text { O poder em nossa empresa está concentrado principalmente nas } \\
\text { mãos do fundador. }\end{array}$ & Existência \\
\hline Distribuição de poder & $\begin{array}{l}\text { O poder na nossa empresa está dividido entre um grupo } \\
\text { composto por vários proprietários / investidores. }\end{array}$ & $\begin{array}{l}\text { Sobrevivênci } \\
\text { a }\end{array}$ \\
\hline Distribuição de poder & $\begin{array}{l}\text { O poder de decisão em nossa empresa está distribuído entre um } \\
\text { grande número de acionistas. }\end{array}$ & Sucesso \\
\hline
\end{tabular}

Fonte: Adaptado de Frezatti et al (2009)

O questionário completo pode ser observado no Apêndice 6. Para cada construto, o respondente podia escolher apenas uma afirmação, aquela que mais se adequasse à realidade de sua empresa. Ao final, classificou-se a empresa no estágio de CVO que apareceu com maior frequência. A vantagem de se trabalhar com esse método reside na simplificação da maneira de classificar as empresas em cada um dos cinco estágios do CVO. 
A desvantagem está na possibilidade dos respondentes assinalarem opções que correspondem a diferentes estágios de CVO em cada construto. Se por um lado, é perfeitamente compreensível que uma organização tenha característica de ciclos distintos, dependendo do construto que se está avaliando, pelo outro, essa possibilidade gera uma dificuldade em se classificar o estágio atual do CVO da empresa quando ocorrem empates entre associação de estágios. Nesses casos, o critério de desempate foi: a idade e o porte da empresa.

Segundo Lester et al (2003, 349), empresas no estágio Existência têm menos de 10 anos. Miller e Friesen (1984, p. 1178) afirmam que, geralmente, os ciclos de Sobrevivência, Sucesso e Reativação tendem a durar cerca de dez anos cada. Na literatura não foi encontrada uma relação entre idade da empresa com o estágio Declínio. Contudo, dadas essas constatações o critério de desempate para classificar o estágio atual de CVO das empresas, em termos de tempo de vida, pode ser visto no Quadro8.

\section{Quadro 8 - Relação entre o estágio de CVO e a idade da empresa}

\begin{tabular}{|l|c|}
\hline Idade da empresa & Estágio do CVO \\
\hline Menos de 10 anos & Existência \\
\hline Entre 10 e 20 anos & Sobrevivência \\
\hline Entre 20 e 30 anos & Sucesso \\
\hline Mais de 30 anos & Reativação \\
\hline
\end{tabular}

Quanto ao porte da empresa, Lester et al (2003, p. 349) afirmam que as empresas no estágio Existência são pequenas, no Sobrevivência, são médias, no estágio Sucesso, são grandes e, no Reativação, são muito grandes. Novamente, não foi encontrada na literatura uma relação entre porte da empresa e o estágio Declínio.

Para classificar as empresas quanto ao porte, o critério utilizado foi o número de empregados. Não se utilizou o critério de faturamento por considerar que as empresas de capital fechado teriam uma maior resistência em fornecer essa informação. Dessa forma, utilizou-se a tabela do Serviço Brasileiro de Apoio às Micro e Pequenas Empresas (SEBRAE) ${ }^{4}$ para classificar as empresas quanto ao porte, conforme Quadro 9.

\footnotetext{
${ }^{4}$ Esse é um critério sugerido pelo SEBRAE quando não se tem acesso à informação sobre o faturamento da empresa. Para fins legais, vale o previsto na Lei do Simples (Lei no 123 de 15 de dezembro de 2006).
} 
Quadro 9 - Relação entre o estágio do CVO e o porte da empresa

\begin{tabular}{|l|c|c|}
\hline Número de empregados & Classificação SEBRAE & Estágio do CVO \\
\hline Menos de 20 & Microempresa & Existência \\
\hline Entre 20 e 99 & Pequena & Sobrevivência \\
\hline Entre 100 e 499 & Média & Sucesso \\
\hline Mais de 500 & Grande & Reativação \\
\hline
\end{tabular}

Fonte: Sebrae,

\subsubsection{Determinação da média de artefatos utilizados por estágio}

Conforme demonstra o Apêndice 7, o instrumento de coleta utilizado nesta dissertação continha sete questões que sobre a utilização ou não de determinados artefatos de controle gerencial. Para cada resposta afirmativa considerou-se um ponto nesse quesito, portanto, o máximo de pontos que poderiam ser obtido por empresa era sete, e o mínimo zero.

Para analisar se as empresas nos estágios mais avançados correspondem as que utilizam maior quantidade de artefatos de controle gerencial, primeiramente cada empresa foi classificada de acordo com o estágio atual de MGL e do CVO, conforme procedimentos descritos anteriormente, em seguida, utilizaram-se o critério de média simples de quantidade de artefatos utilizados por estágio. Nessa análise, os estágios são classificados em ordem decrescente, considerando a média de utilização de artefatos de controle gerencial.

Em seguida, realizou-se um teste estatístico para verificar se a diferença entre a média de utilização de artefatos nos estágios dos dois modelos teóricos é significativa. O mesmo procedimento foi repetido para utilização de artefatos e o perfil das empresas (idade e porte).

\subsubsection{Análise de correspondência (ANACOR)}

Os pesquisadores são constantemente confrontados com a necessidade de quantificar os dados qualitativos encontrados em variáveis não métricas (HAIR, 2005, p. 444). Segundo Fávero et al (2009, p. 272), a ANACOR “[...] é uma técnica que exibe as associações entre um conjunto de variáveis não métricas em um mapa perceptual".

Hair et al (2005, p. 422) explicam que o mapa perceptual é a representação visual de percepções que um respondente tem sobre objetos em duas ou mais dimensões e que cada 
objeto tem uma representação espacial, que reflete a similaridade relativa a outros objetos no que se refere às dimensões do mapa perceptual.

A ANACOR trabalha com variáveis não métricas e, nesse estudo, serão utilizadas variáveis categóricas, ou seja, as categorias (estágios) referentes a MGL e ao CVO. No mapa perceptual as dimensões representam as características de um objeto (HAIR et al, 2005, p. 422)

O número de dimensões do mapa perceptual também depende da quantidade de categorias identificadas. O número máximo de dimensões (eixos nos gráficos) que pode ser estimado é um a menos do que o menor número entre a quantidade de linhas e colunas (FÁVERO et al, 2007, p. 274). Nesta pesquisa, o número máximo de dimensões é quatro, pois tanto o número de linhas e colunas identificadas é igual a cinco.

No entanto, Hair et al (2005, p. 445) explicam que é o pesquisador quem deve definir o número de dimensões, com base na variância explicada e na explicação extra, obtida por cada dimensão. Quanto mais simples for o mapeamento perceptual, mais fácil será sua interpretação. A princípio, deseja-se trabalhar com duas dimensões (MGL e CVO), porém, essa decisão está baseada no autovalor de cada dimensão que será apresentada e discutida na Análise dos Resultados.

A ANACOR consiste em duas etapas básicas, uma referente ao cálculo da medida de associação e a outra é a criação do mapa perceptual (FÁVERO et al, 2009, p. 273). A primeira etapa está baseada no cálculo do Qui-quadrado. Para realizar esse teste, a quantidade de empresas classificadas nos estágios de cada modelo é organizada em uma "tabela de contingência", que é uma tabulação cruzada de duas variáveis não métricas ou categóricas na qual as entradas são as frequências das respostas que "caem" em cada célula da matriz (HAIR et al, 2005, p. 423).

$\mathrm{Na}$ presente pesquisa, cada célula da tabela de contingência representa a quantidade de empresas agrupadas em uma combinação, de tal forma que as linhas representam a classificação em um estágio X do modelo de MGL e as colunas, em um estágio Y do modelo de CVO. 
O Qui-quadrado é o método padronizado que utiliza os dados da tabela de contingência (com os valores observados na pesquisa) para comparar com as frequências esperadas em cada célula, em que a frequência esperada é baseada nas probabilidades marginais das linhas e colunas da matriz (HAIR et al, 2005, p. 423).

O teste Qui-quadrado verifica a distância entre as frequências observadas e as esperadas em cada célula e transforma esse valor em uma medida de distância para concluir se há associações entre as variáveis ou se as similaridades são aleatórias. Esse teste assume como hipótese nula que as duas variáveis são independentes (FÁVERO et al, 2007, p. 276). Portanto, para confirmar a primeira hipótese de pesquisa, de que há associação entre as variáveis os estágios dos modelos de MGL e CVO, espera-se a rejeição de $\mathrm{H}_{0}$ desse teste.

Uma vez rejeitada a hipótese nula do teste Qui-quadrado, pode-se começar a segunda etapa da ANACOR, que é a construção do mapa perceptual (FÁVERO et al, 2007, p. 276). O objetivo desse relatório é colocar as categorias (grupo de empresas classificadas em cada estágio dos modelos) em um plano de dimensões ortogonais para melhor visualizar as distâncias entre esses grupos e explicar a intensidade das associações (HAIR et al, 2005, p. 443).

Em síntese, a primeira hipótese de pesquisa (H1), bem como as quatro hipóteses específicas dela derivadas $\left(\mathrm{H} 1_{\mathrm{A}}, \mathrm{H} 1_{\mathrm{B}}, \mathrm{H} 1_{\mathrm{C}}, \mathrm{H} 1_{\mathrm{D}}\right)$, foram testadas por meio da técnica multivariada ANACOR.

\subsection{Tratamentos e limitações da pesquisa}

O maior desafio da pesquisa no campo das Ciências Sociais é conseguir entender e explicar fenômenos que não podem ser observados diretamente (MARTINS; THEÓPHILO, 2009, p. 93). Para suplantar essa dificuldade, o pesquisador pode utilizar diversas técnicas. Nesse trabalho, o caminho escolhido foi a aplicação de um questionário direcionado a um público alvo específico: profissionais que atuam em gestão logística. Portanto, a primeira limitação é o fato de que as análises e discussões são baseadas nas percepções dos respondentes sobre os temas tratados. 
Em estudos que utilizam a técnica de questionário, uma grande preocupação é quanto ao tamanho da amostra, pois quanto maior a amostra, mais significativos e abrangentes serão os achados. Para superar essa dificuldade, foram estabelecidos contatos com entidades ligadas à prática logística e de gestão da cadeia de suprimentos, visando alcançar o tamanho de amostra pretendido, portanto o tamanho da amostra não se constituiu uma limitação deste trabalho.

Outra preocupação quando se trabalha com questionários diz respeito à confiabilidade das respostas coletadas, uma vez que os dados são obtidos a partir de percepções dos respondentes. Para mensurar a confiabilidade, utilizou-se o alfa de Cronbach, que demonstrou haver consistência interna nas respostas recebidas, portanto, o padrão de respostas dos participantes também não se constituiu uma limitação.

Outra limitação importante quando se trabalha com modelos teóricos é que, apesar destes representarem a operacionalização da interpretação de uma teoria, é apenas a simplificação da realidade (MARTINS; THEÓPHILO, 2009, p. 29). Portanto, o modelo de maturidade da gestão logística não captura a complexidade das diferentes cadeias de suprimento, tampouco o modelo de ciclo de vida consegue capturar todas as variáveis que configuram o estágio atual de ciclo de vida de uma organização.

O caminho selecionado nesta dissertação para verificar as associações entre os estágios também possui um limitação importante. A ANACOR é uma técnica exploratória, portanto, é possível fazer inferências sobre as associações com base estatística, mas não é possível confirmar que tais associações são verdadeiras, pois esta não é uma técnica confirmatória. Entretanto, Hair et al (2005, p. 441) afirmam que esta é uma técnica que tem se tornado cada vez mais popular para o mapeamento perceptual. 


\section{APRESENTAÇÃO E DISCUSSÃO DOS RESULTADOS}

Neste capítulo serão apresentados e discutidos os resultados obtidos através das respostas ao formulário eletrônico. O capítulo está estruturado em cinco seções em que serão analisados: (1) o perfil dos participantes desta pesquisa, (2) a classificação das empresas em estágios de MGL, (3) a classificação nos estágios do CVO, (4) relação entre estágios de desenvolvimento dos dois modelos e, (5) a utilização de artefatos de controle gerencial.

\subsection{Análise do perfil dos participantes}

O formulário eletrônico continha um texto inicial, explicando os objetivos da pesquisa e um termo de compromisso de confidencialidade das informações recebidas (Apêndice 1). Em seguida, havia um grupo de seis questões cujo objetivo era de identificar o perfil do respondente e da empresa participante (Apêndice 2).

A primeira análise realizada para traçar um perfil das empresas e dos profissionais que participaram dessa pesquisa foi relacionada à idade e ao porte das empresas. Conforme discutido nos Procedimentos metodológicos, a variável que mensura o porte das empresas é o seu número de empregados.

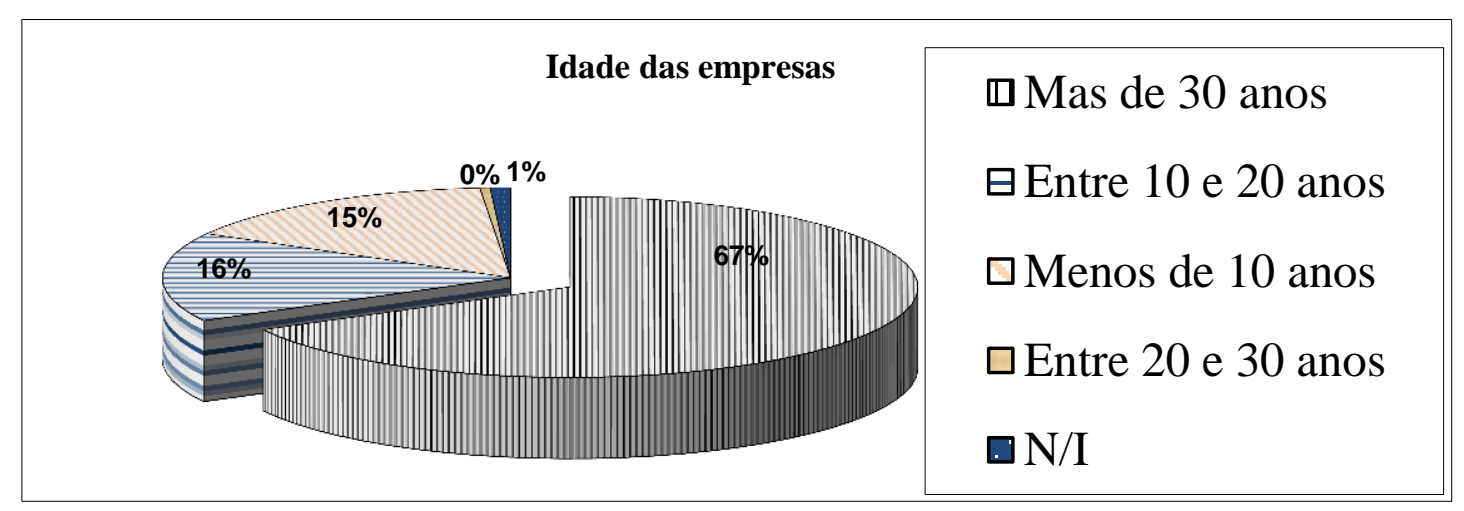

Gráfico 2 - Distribuição das empresas por idade

No Gráfico 2, pode ser observado que a maioria das empresas (67\%) que participaram dessa pesquisa tem mais de 30 anos de existência. Miller e Friesen (1984, p. 1178) argumentam que 
cada ciclo de vida da organização dura, em média, dez anos. Portanto, espera-se que tais empresas estejam classificadas nos estágios mais desenvolvidos do ciclo de vida.

Quanto ao porte, constatou-se que, das 213 empresas participantes, 56\% possuem mais do que 500 empregados, sendo classificadas como Grande e $21 \%$ possuem entre 100 e 499 empregados, sendo classificadas como Médias. Existem, ainda, 13\% com 20 a 99 empregados e $10 \%$ que possuem menos do que 20 trabalhadores, sendo classificadas como Pequena e Micro empresas, respectivamente.

O Gráfico 3 ilustra a distribuição das empresas segundo o porte. Também por esse critério era esperado que a maioria das empresas estivesse situada nos estágios mais avançados de desenvolvimento, uma vez que empresas maiores possuem mais recursos para estruturar suas operações.

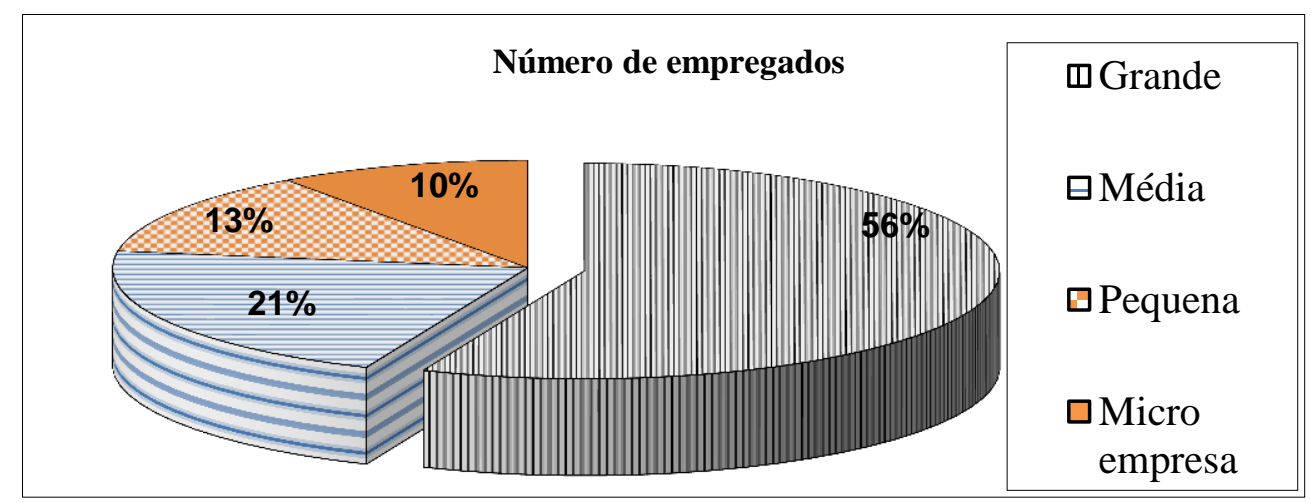

Gráfico 3 - Distribuição das empresas por porte (número de empregados)

Também se buscou traçar o perfil dos respondentes que representavam suas empresas. Dessa forma, perguntou-se a eles qual a posição que ocupam na organização. Desejava-se, principalmente, contatar profissionais de posições mais altas na hierarquia, devido ao maior acesso às informações sistêmicas sobre o processo. Também nesse quesito a pesquisa foi exitosa. Conforme é exibido na tabela 2, a maior parte dos respondentes ocupam posições de liderança, seja na gerência (45\%), diretoria (18\%) ou presidência (2\%). 
Tabela 2 - Distribuição das posições dos respondentes

\begin{tabular}{|l|c|c|}
\hline \multicolumn{1}{|c|}{ Posição } & Total & \% \\
\hline Gerente & 96 & 45 \\
\hline Diretor & 38 & 18 \\
\hline Coordenador & 27 & 13 \\
\hline Analista & 20 & 9 \\
\hline Consultor & 16 & 8 \\
\hline Supervisor & 10 & 5 \\
\hline Presidente & 4 & 2 \\
\hline Outro & 2 & 1 \\
\hline Total Geral & $\mathbf{2 1 3}$ & $\mathbf{1 0 0}$ \\
\hline
\end{tabular}

Além da posição, os participantes foram questionados sobre a sua principal área de atuação na organização. O modelo de maturidade da gestão da cadeia de suprimentos de Oliveira (2009) foi concebido a partir de outro, fundamentado no SCOR-4, que fornece uma linguagem orientada a processos para aprimorar a comunicação entre os parceiros da cadeia de suprimentos em quatro áreas de decisão: planejamento, suprimento, produção e, distribuição (LOCKAMY; MCCOMARK, 2004, p. 1192).

Portanto, desejava-se que os participantes tivessem conhecimentos técnicos sobre essas quatro áreas específicas, para compreender as questões e os problemas colocados no formulário. Felizmente, constatou-se ao final do período de recebimento de respostas, que $69 \%$ desses profissionais atuam nas áreas de planejamento interno (18\%) e externo (16\%), suprimento (13\%), produção (15\%) e, distribuição (7\%). A tabela 3 exibe a distribuição dos respondentes por área.

Tabela 3 - Quantidade de respondente por área de atuação

\begin{tabular}{|l|c|c|}
\hline \multicolumn{1}{|c|}{ Área } & Total & $\mathbf{\%}$ \\
\hline Gestão logística interna & 39 & 18 \\
\hline Gestão logística externa & 34 & 16 \\
\hline Operações / produção & 32 & 15 \\
\hline Compras / suprimentos & 27 & 13 \\
\hline Outra & 20 & 9 \\
\hline Distribuição & 15 & 7 \\
\hline Controladoria & 12 & 6 \\
\hline Administração & 11 & 5 \\
\hline Serviço ao cliente & 10 & 5 \\
\hline Marketing / vendas & 7 & 3 \\
\hline Financeira & 6 & 3 \\
\hline Total Geral & $\mathbf{2 1 3}$ & $\mathbf{1 0 0}$ \\
\hline
\end{tabular}


Assim, em síntese, o perfil dos participantes pode ser descrito como: "profissionais das principais áreas de gestão logística com cargos de liderança, em empresas de grande porte e com mais de 30 anos de existência”.

\subsection{Classificação do estágio de maturidade da gestão logística (MGL)}

A classificação do estágio atual de maturidade da gestão logística das empresas foi realizada a partir de atribuições do grau de concordância de seus representantes a determinadas situações. O determinante para essa classificação foi o escore total para as 25 situações que lhes foram propostas (Apêndice 4). Depois de somar as atribuições em cada uma das questões, verificouse qual o estágio correspondente, de acordo com o Quadro 6, do capítulo anterior.

Ao analisar a atribuição de escore das empresas por questão (Quadro 10), é possível identificar onde estão concentrados os principais pontos fortes e fracos da gestão logística das empresas, segundo a percepção dos respondentes. Por exemplo, nos construtos Construção da fundação (C-01) e Gestão de pedidos (C-02), que compõem o primeiro estágio do modelo (Fundação), a maior parte dos respondentes atribuiu escores 4 e 5 para as questões, porém, no que se refere aos construtos Integração com clientes (C-09) e Gestão da rede de fornecedores (C-10), a atribuição dos escores concentrou-se em 1, demonstrando uma deficiência nessas competências. O Quadro 10 demonstra o percentual de atribuição para cada uma das questões.

As questões 16 e 18, sobre a integração do sistema da empresa com o do cliente e fornecedores, foram as que obtiveram as menores atribuições de escores (31\% dos respondentes atribuíram escore 1 à questão 16, enquanto que 30\% fizeram o mesmo para a questão 18). Isso indica que as empresas pesquisadas, no mínimo, estão perdendo uma oportunidade de ganhar eficiência no processamento de informação através da integração com seus clientes e fornecedores.

Por outro lado, nas questões 22 e 23 (C-12), que versam sobre a comunicação das mudanças nos processos logísticos e adoção de práticas de melhoramento contínuo, respectivamente, a maior concentração de atribuição foi no escore quatro, demonstrando que, apesar de não estarem integrados com clientes e fornecedores, há a preocupação em manter ativo o canal de comunicação entre os parceiros da cadeia de suprimentos. 
Quadro 10 - Matriz de atribuição de escore por questão

\begin{tabular}{|c|c|c|c|c|c|c|c|}
\hline \multirow{2}{*}{ Estágio } & \multirow{2}{*}{ Construtos } & \multirow{2}{*}{ Qestões } & \multicolumn{5}{|c|}{ Escore atribuído / percentual de empresas } \\
\hline & & & 1 & 2 & 3 & 4 & 5 \\
\hline \multirow{4}{*}{$\begin{array}{c}1 \\
\text { Fundação }\end{array}$} & \multirow{2}{*}{ Construção da Fundação/C-01 } & Q-01 & $6 \%$ & $13 \%$ & $23 \%$ & $34 \%$ & $24 \%$ \\
\hline & & Q-02 & $3 \%$ & $6 \%$ & $16 \%$ & $32 \%$ & $42 \%$ \\
\hline & \multirow{2}{*}{ Gestão de pedidos/C-02 } & Q-03 & $3 \%$ & $4 \%$ & $10 \%$ & $24 \%$ & $59 \%$ \\
\hline & & Q-04 & $5 \%$ & $11 \%$ & $27 \%$ & $30 \%$ & $27 \%$ \\
\hline \multirow{6}{*}{2 Estrutura } & \multirow{2}{*}{ Gestão da rede de distribuição/C-03 } & Q-05 & $14 \%$ & $17 \%$ & $27 \%$ & $20 \%$ & $22 \%$ \\
\hline & & Q-06 & $4 \%$ & $9 \%$ & $22 \%$ & $40 \%$ & $25 \%$ \\
\hline & \multirow{2}{*}{ Previsão e gestão da demanda/C-04 } & Q-07 & $10 \%$ & $19 \%$ & $20 \%$ & $23 \%$ & $28 \%$ \\
\hline & & Q-08 & $9 \%$ & $19 \%$ & $23 \%$ & $29 \%$ & $19 \%$ \\
\hline & \multirow{2}{*}{ Planejamento e controle da produção/C-05 } & Q-09 & $4 \%$ & $11 \%$ & $19 \%$ & $31 \%$ & $35 \%$ \\
\hline & & Q-10 & $9 \%$ & $14 \%$ & $26 \%$ & $25 \%$ & $26 \%$ \\
\hline \multirow{5}{*}{$\begin{array}{c}3 \\
\text { Visão }\end{array}$} & \multirow{2}{*}{ Equipe de compras/C-06 } & Q-11 & $9 \%$ & $16 \%$ & $23 \%$ & $26 \%$ & $25 \%$ \\
\hline & & Q-12 & $5 \%$ & $9 \%$ & $18 \%$ & $27 \%$ & $41 \%$ \\
\hline & \multirow{2}{*}{ Governança de processos/C-07 } & Q-13 & $8 \%$ & $9 \%$ & $16 \%$ & $21 \%$ & $46 \%$ \\
\hline & & Q-14 & $14 \%$ & $17 \%$ & $23 \%$ & $27 \%$ & $19 \%$ \\
\hline & Planejamento estratégico em equipe/C-08 & Q-15 & $7 \%$ & $9 \%$ & $24 \%$ & $28 \%$ & $33 \%$ \\
\hline \multirow{6}{*}{$\begin{array}{c}4 \\
\text { Integração }\end{array}$} & \multirow{2}{*}{ Integração com clientes/C-09 } & Q-16 & $31 \%$ & $21 \%$ & $17 \%$ & $16 \%$ & $15 \%$ \\
\hline & & Q-17 & $15 \%$ & $18 \%$ & $27 \%$ & $23 \%$ & $17 \%$ \\
\hline & \multirow{2}{*}{ Gestão da rede de fornecedores/C-10 } & Q-18 & $30 \%$ & $21 \%$ & $22 \%$ & $16 \%$ & $11 \%$ \\
\hline & & Q-19 & $4 \%$ & $7 \%$ & $22 \%$ & $37 \%$ & $31 \%$ \\
\hline & \multirow{2}{*}{ Comportamento estratégico/C-11 } & Q-20 & $11 \%$ & $20 \%$ & $24 \%$ & $31 \%$ & $14 \%$ \\
\hline & & Q-21 & $12 \%$ & $20 \%$ & $28 \%$ & $26 \%$ & $14 \%$ \\
\hline \multirow{4}{*}{$\begin{array}{c}5 \\
\text { Dinâmica }\end{array}$} & \multirow{2}{*}{ Praticas colaborativas integradas/C-12 } & Q-22 & $10 \%$ & $16 \%$ & $23 \%$ & $33 \%$ & $18 \%$ \\
\hline & & Q-23 & $9 \%$ & $14 \%$ & $22 \%$ & $28 \%$ & $27 \%$ \\
\hline & \multirow{2}{*}{ Responsividade/C-13 } & Q-24 & $13 \%$ & $20 \%$ & $21 \%$ & $20 \%$ & $27 \%$ \\
\hline & & Q-25 & $10 \%$ & $19 \%$ & $34 \%$ & $24 \%$ & $13 \%$ \\
\hline
\end{tabular}

No Quadro 10, percebe-se que a maior quantidade de adesões a um único escore é observada na questão 3, em que 59\% dos respondentes atribuíram 5 pontos. Essa questão versava sobre a documentação, gestão e controle de pedidos dos clientes. $\mathrm{O}$ alto índice de atribuições de escore 5 a essa questão contribuiu para que o construto Gestão de pedidos (C-02) fosse o aquele com maior percentual de escores, em relação ao total, obtendo $80 \%$ da pontuação máxima. O Gráfico 4 indica o percentual de escores atribuído em cada constructo. 


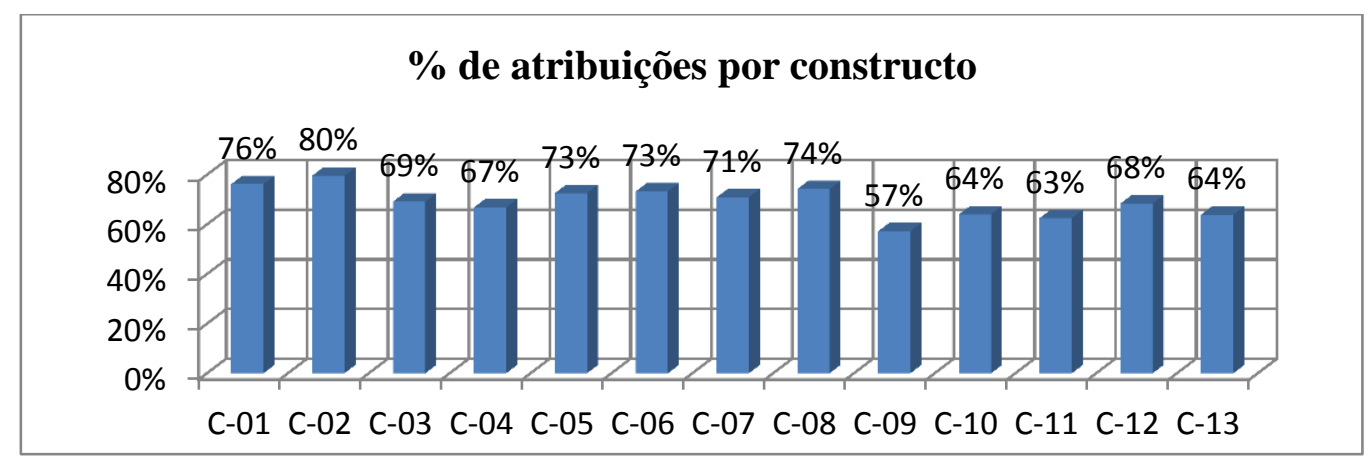

Gráfico 4 - Percentual de escores atribuído por código de constructo.

Conforme pode ser observado, os construtos mais avançados, por exemplo, do C-09 ao C-13, foram os que tiveram menor percentual de atribuições, em relação à pontuação máxima, sendo o constructo C-09 (Integração com clientes) aquele que obteve menor índice. Apesar disso, a maioria das empresas (56\%) foi classificada nos dois estágios mais avançados do modelo.

A Tabela 4 demonstra a distribuição das 213 empresas da amostra nos estágios de maturidade da gestão logística (MGL): Dinâmica (29\%), Integração (27\%), Visão (20\%), Estrutura (15\%) e Fundação (9\%).

Tabela 4 - Classificação das empresas nos estágios de MGL

\begin{tabular}{|l|c|c|}
\hline \multicolumn{3}{|c|}{ Distribuição das empresas por estágio de MGL } \\
\hline \multicolumn{1}{|c|}{ Estágio } & Quantidade de empresas & $\%$ \\
\hline DINÂMICA & 61 & 29 \\
INTEGRAÇÃ̃ & 58 & 27 \\
VISÃO & 42 & 20 \\
ESTRUTURA & 33 & 15 \\
FUNDAÇÃO & 19 & 9 \\
\hline Total Geral & 213 & 100 \\
\hline
\end{tabular}

Após analisar a classificação das empresas nos estágios de MGL pelo critério de competência (construtos) da gestão logística, foi investigado se essas categorias estavam relacionadas a idade (Tabela 5) e o porte das empresas (Tabela 6).

Tabela 5 - Relação entre idade das empresas e classificação da MGL

\begin{tabular}{|l|c|c|c|c|c|c|}
\hline \multicolumn{1}{|c|}{ IDADE } & FUNDAÇÃO & ESTRUTURA & VISÃO & INTEGRAÇÃO & DINÂMICA & Total \\
\hline Mais de 30anos & 10 & 20 & 27 & 41 & 45 & 143 \\
Entre 20 e 30anos & - & - & - & - & 1 & 1 \\
Entre 10 e 20anos & 7 & 4 & 6 & 12 & 5 & 34 \\
Menos de 10anos & 2 & 9 & 9 & 4 & 9 & 33 \\
NI & - & - & - & 1 & 1 & 2 \\
\hline Total & $\mathbf{1 9}$ & $\mathbf{3 3}$ & $\mathbf{4 2}$ & $\mathbf{5 8}$ & $\mathbf{6 1}$ & $\mathbf{2 1 3}$ \\
\hline
\end{tabular}


Na Tabela 5 é evidenciada a quantidade de empresas por faixa de idade. A análise superficial dos dados dá indícios de não haver associação entre idade e classificação. Por exemplo, no grupo das 33 empresas com menos 10 anos não há uma definição clara de qual o estágio dominante, visto que três deles - Estrutura, Visão e Dinâmica - foi observado a mesma quantidade de empresas (nove organizações em cada um). Para verificar a ausência de correlação entre idade da empresa e estágio de MGL, realizou-se o teste de Kruskal-Wallis.

Quadro 11 - Teste de média entre idade e estágios de MGL das empresas

\begin{tabular}{|c|c|}
\hline Teste Estatístico $(\mathbf{a}, \mathbf{b})$ & Valor \\
\hline Qui-quadrado & 8,122 \\
\hline Sig. & 0,087 \\
\hline
\end{tabular}

Conforme visto no Quadro 11, há evidências estatísticas ao nível de significância de 5\%, para aceitar a hipótese nula de que não há diferença significativa entre os grupos de idade das empresas na classificação do estágio de MGL. Dessa forma, concluímos que a idade da empresa não é significativa para sua classificação nos estágios de MGL. Em seguida, analisase a relação entre esses estágios e o porte das empresas (Tabela 6).

Tabela 6 - Relação entre porte das empresas e classificação da MGL

\begin{tabular}{|l|c|c|c|c|c|c|}
\hline PORTE & FUNDAÇÃO & ESTRUTURA & VISÃO & INTEGRAÇÃO & DINÂMICA & Total \\
\hline Grande & 11 & 12 & 21 & 35 & 41 & $\mathbf{1 2 0}$ \\
Médio & 3 & 7 & 13 & 12 & 10 & $\mathbf{4 5}$ \\
Pequeno & 4 & 7 & 3 & 7 & 6 & $\mathbf{2 7}$ \\
Micro & 1 & 7 & 5 & 4 & 4 & $\mathbf{2 1}$ \\
\hline Total & $\mathbf{1 9}$ & $\mathbf{3 3}$ & $\mathbf{4 2}$ & $\mathbf{5 8}$ & $\mathbf{6 1}$ & $\mathbf{2 1 3}$ \\
\hline
\end{tabular}

Novamente, pela análise superficial da relação entre a distribuição das empresas nos estágios de MGL e o porte das mesmas, parece não haver associação entre esses dois critérios. Outra vez, realizou-se o teste de Kruskal-Wallis (Quadro 12).

Quadro 12 - Teste de média entre porte de estágios de MGL das empresas

\begin{tabular}{|l|l|}
\hline Teste Estatístico (a,b) & Valor \\
\hline Qui-quadrado & 6,907 \\
Sig. & 0,075 \\
\hline
\end{tabular} a Teste Kruskal Wallis
b Variável testada: PORTE


Com intervalo de confiança de 95\%, o resultado indica não haver evidências estatísticas de associação entre os estágios de MGL com o porte das empresas. Essas análises permitem concluir que a classificação das empresas em estágios de MGL não está relacionada à idade ou ao porte das organizações, mas sim às competências presentes na gestão logística.

\subsection{Classificação dos estágios de ciclo de vida organizacional (CVO)}

Para mensurar o estágio atual de ciclo de vida das organizações, o formulário continha cinco questões. Cada uma tratava de um construto específico do modelo, e tinha de três a cinco alternativas, entre as quais, era permitido ao respondente selecionar apenas uma (Apêndice 6). Cada resposta atribuída está relaciona a um determinado estágio do CVO, conforme visto anteriormente no Quadro 7, do capítulo anterior.

O primeiro construto a ser investigado foi o Ambiente, com uma questão sobre a posição da organização no mercado em termos de tamanho. A resposta mais freqüente $(46 \%)$ foi aquela em que o participante assinalava que trabalhavam em "grandes empresas, com diretores e acionistas”. Essa resposta está relacionada ao estágio Reativação. Esse padrão de respostas, de certa forma, está coerente com as informações sobre o perfil das empresas, que os respondentes assinalaram no início do formulário.

Tabela 7 - Distribuição das respostas no construto Ambiente

\begin{tabular}{|l|l|c|c|}
\hline $\begin{array}{c}\text { Q-01: Qual das afirmações abaixo melhor descreve o AMBIENTE } \\
\text { em que a sua empresa está inserida? }\end{array}$ & Estágio & $\begin{array}{c}\text { Quantidade de } \\
\text { respostas }\end{array}$ & $\%$ \\
\hline $\begin{array}{l}\text { Nossa empresa é pequena, tanto em tamanho quanto em } \\
\text { comparação com nossos concorrentes. }\end{array}$ & Existência & 43 & $\mathbf{2 0}$ \\
\hline $\begin{array}{l}\text { Como uma empresa, nós somos maiores do que a maioria de nossos } \\
\text { concorrentes, mas não tão grande como poderia ser. }\end{array}$ & Sucesso & 72 & 34 \\
\hline Somos uma grande empresa, com diretores e acionistas. & Reativação & $\mathbf{9 8}$ & $\mathbf{4 6}$ \\
\hline Total & & $\mathbf{2 1 3}$ & $\mathbf{1 0 0}$ \\
\hline
\end{tabular}

Em seguida, foi questionada a situação atual da empresa quanto ao seu Modelo de Decisão. Havia, nesse quesito, três opções de resposta e a resposta mais recorrente (41\%) foi que as decisões são tomadas "por gerentes, força tarefa ou equipe de projetos". Essa resposta também está associada ao estágio Reativação, o mais avançado do modelo de CVO. 
Tabela 8 - Distribuição das respostas no construto Modelo de Decisão

\begin{tabular}{|l|c|c|c|}
\hline $\begin{array}{c}\text { Qual situação melhor descreve o MODELO DE DECISÃO na sua } \\
\text { empresa? }\end{array}$ & Estágio & $\begin{array}{c}\text { Quantidade de } \\
\text { respostas }\end{array}$ & $\%$ \\
\hline $\begin{array}{l}\text { A maioria das decisões da nossa empresa é tomada por gerentes, } \\
\text { força tarefa, e equipes de projetos que tentam promover o } \\
\text { crescimento através da participação. }\end{array}$ & Reativação & 87 & 41 \\
\hline $\begin{array}{l}\text { A maioria das decisões da nossa empresa é tomada por um grupo } \\
\text { de gestores que empregam algumas análises sistemáticas, mas que } \\
\text { não são suficientemente ousadas. }\end{array}$ & Sobrevivência & 49 & 23 \\
\hline $\begin{array}{l}\text { O processo decisório é centralizado no topo da organização e não é } \\
\text { considerado muito complexo. }\end{array}$ & Declínio & 77 & 36 \\
\hline Total & & 213 & 100 \\
\hline
\end{tabular}

A terceira questão tratou do construto Estrutura Organizacional, que aborda a forma como as equipes de trabalho estão dispostas na empresa. Nesse ponto, as respostas não ficaram muito concentradas em nenhuma situação, porém, a resposta mais comum $(25 \%)$ foi que "a estrutura organizacional poderia ser descrita como simples", sendo classificados como Existência.

Tabela 9 - Distribuição das respostas no construto Estrutura Organizacional

\begin{tabular}{|l|c|c|c|}
\hline \multicolumn{1}{|c|}{$\begin{array}{c}\text { Qual situação melhor define a ESTRUTURA } \\
\text { ORGANIZACIONAL na sua empresa? }\end{array}$} & Estágio & $\begin{array}{c}\text { Quantidade de } \\
\text { respostas }\end{array}$ & $\%$ \\
\hline $\begin{array}{l}\text { A estrutura de trabalho em nossa empresa é divisional ou } \\
\text { matricial, com sistemas de controles altamente sofisticados. }\end{array}$ & Reativação & 45 & 21 \\
\hline $\begin{array}{l}\text { Estrutura organizacional da nossa empresa poderia ser descrita } \\
\text { como simples. }\end{array}$ & Existência & 54 & 25 \\
\hline $\begin{array}{l}\text { Na nossa organização, há certo nível de especialização (contadores } \\
\text { e possivelmente engenheiros, por exemplo) e estamos de alguma } \\
\text { forma nos tornando diferenciados. }\end{array}$ & Sobrevivência & 48 & 23 \\
\hline $\begin{array}{l}\text { Nossa estrutura é centralizada, com apenas alguns sistemas de } \\
\text { controle. }\end{array}$ & Declínio & 31 & 15 \\
\hline $\begin{array}{l}\text { Nossa estrutura é departamental e funcional e se tornou muito } \\
\text { formal. }\end{array}$ & Sucesso & 35 & 16 \\
\hline Total & & 213 & 100 \\
\hline
\end{tabular}

O construto Processamento de Informações foi abordado na quarta questão. Perguntou-se sobre a funcionalidade e utilização dos sistemas de processamento de informação. A reposta mais recorrente (31\%) foi que "os sistemas de processamento de informações de suas empresas não são utilizados de maneira plena", sendo classificados no estágio Declínio. Esse padrão de resposta, todavia, está coerente com as respostas do questionário de MGL, que apontaram para o baixo índice de integração com o sistema dos clientes. 
Tabela 10 - Distribuição das respostas no construto Processamento de Informações

\begin{tabular}{|c|c|c|c|}
\hline $\begin{array}{l}\text { Qual das situações melhor define o PROCESSAMENTO DE } \\
\text { INFORMAÇÕES na sua empresa? }\end{array}$ & Estágio & $\begin{array}{l}\text { Quantidade de } \\
\text { respostas }\end{array}$ & $\%$ \\
\hline $\begin{array}{l}\text { O processamento de informação é bastante complexo, utilizado } \\
\text { para coordenar diversas atividades e para melhor servir o } \\
\text { Mercado. }\end{array}$ & Reativação & 42 & 20 \\
\hline $\begin{array}{l}\text { O processamento de informação pode ser mais bem descrito como } \\
\text { sendo simples e muitas vezes informal. }\end{array}$ & Existência & 37 & 17 \\
\hline $\begin{array}{l}\text { O processamento de informações é sofisticado e necessário para } \\
\text { gerar uma produção eficiente e lucratividade adequada. }\end{array}$ & Sucesso & 27 & 13 \\
\hline $\begin{array}{l}\text { O processamento de informações monitora desempenho e facilita } \\
\text { a comunicação entre os departamentos. }\end{array}$ & Sobrevivência & 42 & 20 \\
\hline $\begin{array}{l}\text { O processamento de informações não é utilizado da maneira } \\
\text { plena. }\end{array}$ & Declínio & 65 & 31 \\
\hline Total & & 213 & 100 \\
\hline
\end{tabular}

A quinta e última questão do CVO abordou o construto Poder na organização. Em síntese, a questão versava sobre quem efetivamente manda na empresa. A resposta mais comum $(40 \%)$ foi que "o poder está concentrado nas mãos do fundador", sendo classificados no estágio Existência. Esse padrão de resposta, porém, parece adequado ao padrão das empresas brasileiras, no que se refere à concentração de poder. Segundo Assaf Neto et al (2008, p. 82), a maioria das empresas brasileiras são de capital fechado, concentrado nas mãos de poucos participantes.

Tabela 11 - Distribuição das respostas no construto Poder

\begin{tabular}{|c|c|c|c|}
\hline $\begin{array}{l}\text { Qual das situações melhor descreve a concentração do PODER } \\
\text { na sua empresa? }\end{array}$ & Estágio & $\begin{array}{l}\text { Quantidade de } \\
\text { respostas }\end{array}$ & $\%$ \\
\hline $\begin{array}{l}\text { O poder de decisão em nossa empresa está distribuído entre um } \\
\text { grande número de acionistas. }\end{array}$ & Sucesso & 50 & 23 \\
\hline $\begin{array}{l}\text { O poder em nossa empresa está concentrado principalmente nas } \\
\text { mãos do fundador. }\end{array}$ & Existência & 86 & 40 \\
\hline $\begin{array}{l}\text { O poder na nossa empresa está dividido entre um grupo } \\
\text { composto por vários proprietários / investidores. }\end{array}$ & Sobrevivência & 77 & 36 \\
\hline Total & & 213 & 100 \\
\hline
\end{tabular}

Na Tabela 12, é apresentada a distribuição das respostas em cada estágio do modelo de ciclo de vida para cada um dos cinco construtos. Observa-se que o estágio Reativação prevalece em dois construtos, enquanto que o Existência, em outros dois, o estágio Declínio prevaleceu no construto que aborda o tema processamento de informações. 
Tabela 12 - Matriz de respostas por construto e estágios de CVO

\begin{tabular}{|l|c|c|c|c|c|c|}
\hline \multirow{2}{*}{ Construtos } & \multirow{2}{*}{ Questões } & \multicolumn{5}{c|}{ Estágios de ciclo de vida organizacional } \\
\cline { 3 - 7 } & & Existência & Sobrevivência & Sucesso & Reativação & Declínio \\
\hline Ambiente & Q-01 & $20 \%$ & - & $34 \%$ & $46 \%$ & - \\
\hline Modelo de decisão & Q-02 & - & $23 \%$ & - & $41 \%$ & $36 \%$ \\
\hline Estrutura organizacional & Q-03 & $25 \%$ & $23 \%$ & $16 \%$ & $21 \%$ & $15 \%$ \\
\hline Processamento de informações & Q-04 & $17 \%$ & $20 \%$ & $13 \%$ & $20 \%$ & $31 \%$ \\
\hline Distribuição de poder & Q-05 & $40 \%$ & $36 \%$ & $23 \%$ & - & - \\
\hline
\end{tabular}

Dada essa proporção, observa-se que a maior parte das empresas pesquisas encontra-se no estágio Reativação (36\%) e Existência (23\%), seguido pelos estágios de Sobrevivência (18\%), Sucesso (12\%) e Declínio (12\%), conforme é demonstrado na Tabela 13.

Tabela 13 - Quantidade de empresa classificada em cada estágio do CVO

\begin{tabular}{|l|c|c|}
\hline \multicolumn{2}{|c|}{ Quantidade de empresas por estágio de CVO } \\
\hline \multicolumn{1}{|c|}{ Estágio } & Total & $\%$ \\
\hline REATIVAÇÃO & 76 & 36 \\
EXISTÊNCIA & 49 & 23 \\
SOBREVIVÊNCIA & 38 & 18 \\
SUCESSO & 25 & 12 \\
DECLÍNIO & 25 & 12 \\
\hline Total Geral & 213 & 100 \\
\hline
\end{tabular}

Realizou-se também análise da distribuição das empresas nos estágios do CVO por idade (Tabela 14) e porte (Tabela 15) dessas organizações. Entretanto, nesse caso, os testes estatísticos (Kruskal-Wallis) demonstraram que há associação entre a idade e o porte das empresas e a sua classificação nos estágios do CVO (Quadro 13).

Tabela 14 - Relação entre idade da empresa e classificação no CVO

\begin{tabular}{|l|c|c|c|c|c|c|}
\hline \multicolumn{1}{|c|}{ IDADE } & EXISTÊNCIA & SOBREVIVÊNCIA & SUCESSO & REATIVAÇÃO & DECLÍNIO & Total \\
\hline Mais de 30anos & 20 & 25 & 22 & 59 & 17 & $\mathbf{1 4 3}$ \\
Entre 20 e 30anos & 1 & - & - & - & - & $\mathbf{1}$ \\
Entre 10 e 20anos & 11 & 6 & 3 & 9 & 5 & $\mathbf{3 4}$ \\
Menos de 10anos & 17 & 7 & - & 7 & 2 & $\mathbf{3 3}$ \\
NI & - & - & - & 1 & 1 & $\mathbf{2}$ \\
\hline \multicolumn{1}{|c|}{ Total } & $\mathbf{4 9}$ & $\mathbf{3 8}$ & $\mathbf{2 5}$ & $\mathbf{7 6}$ & $\mathbf{2 5}$ & $\mathbf{2 1 3}$ \\
\hline
\end{tabular}

Na Tabela 14, pode-se observar que as empresas com mais de 30 anos de existência foram classificadas, predominantemente, no estágio Reativação. Já as empresas com menos de 10 anos foram classificadas, predominantemente, no estágio Existência. 
Tabela 15 - Relação entre porte da empresa e classificação no CVO

\begin{tabular}{|l|c|c|c|c|c|c|}
\hline Categoria & EXISTÊNCIA & SOBREVIVÊNCIA & SUCESSO & REATIVAÇÃO & DECLÍNIO & Total \\
\hline Grande & 9 & 21 & 17 & 60 & 13 & $\mathbf{1 2 0}$ \\
Média & 12 & 7 & 7 & 12 & 7 & $\mathbf{4 5}$ \\
Pequena & 12 & 8 & 1 & 2 & 4 & $\mathbf{2 7}$ \\
Micro empresa & 16 & 2 & 0 & 2 & 1 & $\mathbf{2 1}$ \\
\hline \multicolumn{1}{|c|}{ Total } & $\mathbf{4 9}$ & $\mathbf{3 8}$ & $\mathbf{2 5}$ & $\mathbf{7 6}$ & $\mathbf{2 5}$ & $\mathbf{2 1 3}$ \\
\hline
\end{tabular}

Na Tabela 15, percebe-se que as grandes empresas foram classificadas, predominantemente, no estágio Reativação, enquanto que a maior parte das Micro-empresas foi classificada no estágio Existência. Esses dados sugerem que tanto a idade da empresa, quanto o seu porte é importante para a classificação nos estágios do CVO.

Quadro 13 - Teste de média entre CVO, Idade e Porte das empresas

\begin{tabular}{|l|r|r|}
\hline Kruskal-Wallis & CVO-Idade & CVO-Porte \\
\hline Qui-quadrado & 20,900 & 38,021 \\
Sig. & 0,000 & 0,000 \\
\hline
\end{tabular}

\subsection{Relação entre estágios de MGL e CVO}

A investigação da relação entre os estágios de maturidade da gestão logística (MGL) e do ciclo de vida organizacional (CVO) foi realizada através da análise de correspondência (ANACOR), com a utilização do software estatístico Statistical Package for Social Science (SPSS).

Inicialmente, foi efetuado o teste de Qui-quadrado. Para realizá-lo, deve-se construir a tabela de contingência, em que cada célula da matriz contém o número observado de empresas classificadas nos estágios de MGL e CVO (Tabela 16). 
Tabela 16 - Tabela de contingência

\begin{tabular}{|c|c|c|c|c|c|c|}
\hline MGL / CVO & EXISTÊNCIA & SOBREVIVÊNCIA. & SUCESSO & REATIVAÇÃO & DECLÍNIO & Total \\
\hline FUNDAÇÃO & 6 & 2 & 2 & 2 & 7 & 19 \\
\hline ESTRUTURA & 18 & 2 & 4 & 4 & 5 & 33 \\
\hline VISÃO & 12 & 7 & 4 & 13 & 6 & 42 \\
\hline INTEGRAÇÃO & 8 & 14 & 8 & 23 & 5 & 58 \\
\hline DINÂMICA & 5 & 13 & 7 & 34 & 2 & 61 \\
\hline Total & 49 & 38 & 25 & 76 & 25 & 213 \\
\hline
\end{tabular}

A partir da tabela de contingência é calculada a frequência esperada de cada célula, baseada nas probabilidades marginais das linhas e colunas da matriz (HAIR et al, 2005, p. 423). Em seguida, calcula-se a diferença entre as frequências observadas e esperadas (Tabela 17).

Tabela 17 - Cálculo da diferença entre valor observado e valor esperado

\begin{tabular}{|c|c|c|c|c|c|c|c|}
\hline MGL / CVO & & EXISTÊNCIA & SOBREVIVÊNCIA & SUCESSO & REATIVAÇÃO & DECLÍNIO & Total \\
\hline \multirow[t]{3}{*}{ FUNDAÇÃO } & Observado & 6,00 & 2,00 & 2,00 & 2,00 & 7,00 & 19 \\
\hline & Esperado & 4,37 & 3,39 & 2,23 & 6,78 & 2,23 & 19 \\
\hline & Diferença & 1,63 & $-1,39$ & $-0,23$ & $-4,78$ & 4,77 & \\
\hline \multirow[t]{3}{*}{ ESTRUTURA } & Observado & 18,00 & 2,00 & 4,00 & 4,00 & 5,00 & 33 \\
\hline & Esperado & 7,59 & 5,89 & 3,87 & 11,77 & 3,87 & 33 \\
\hline & Diferença & 10,41 & $-3,89$ & 0,13 & $-7,77$ & 1,13 & \\
\hline \multirow[t]{3}{*}{ VISÃO } & Observado & 12,00 & 7,00 & 4,00 & 13,00 & 6,00 & 42 \\
\hline & Esperado & 9,66 & 7,49 & 4,93 & 14,99 & 4,93 & 42 \\
\hline & Diferença & 2,34 & $-0,49$ & $-0,93$ & $-1,99$ & 1,07 & \\
\hline \multirow[t]{3}{*}{$\begin{array}{l}\text { INTEGRAÇÃ } \\
\text { O }\end{array}$} & Observado & 8,00 & 14,00 & 8,00 & 23,00 & 5,00 & 58 \\
\hline & Esperado & 13,34 & 10,35 & 6,81 & 20,69 & 6,81 & 58 \\
\hline & Diferença & $-5,34$ & 3,65 & 1,19 & 2,31 & $-1,81$ & \\
\hline \multirow[t]{3}{*}{ DINÂMICA } & Observado & 5,00 & 13,00 & 7,00 & 34,00 & 2,00 & 61 \\
\hline & Esperado & 14,03 & 10,88 & 7,16 & 21,77 & 7,16 & 61 \\
\hline & Diferença & $-9,03$ & 2,12 & $-0,16$ & 12,23 & $-5,16$ & \\
\hline \multirow[t]{2}{*}{ Total } & Observado & 49 & 38 & 25 & 76 & 25 & 213 \\
\hline & Esperado & 49 & 38 & 25 & 76 & 25 & 213 \\
\hline
\end{tabular}

O teste Qui-quadrado verifica a diferença entre as frequências observadas e esperadas em cada célula e transforma esse valor em uma medida de distância para concluir se há associações entre as variáveis ou se as similaridades são aleatórias. Fávero et al (2007, p. 276) explicam que esse teste assume como hipótese nula que as duas variáveis são independentes.

Conforme resultado do Quadro 14, não há evidências estatísticas para aceitar a hipótese nula, ao nível de significância de $5 \%$, de independência entre os estágios dos dois modelos. Portanto, o teste indica que há uma associação, não aleatória, entre os estágios de MGL e do CVO. 
Quadro 14 - Teste Qui-quadrado entre estágios de MGL e CVO

\begin{tabular}{|l|c|c|}
\hline \multicolumn{1}{|c|}{ Teste } & Valor & Sig. \\
\hline Qui-quadrado & 59,54 & 0,00 \\
Total (classificações) & 213 & \\
\hline
\end{tabular}

O resultado do teste Qui-quadrado não apenas possibilita que se possa seguir na aplicação da ANACOR, como também permite responder à primeira hipótese desta dissertação:

H1: Existe associação não aleatória entre os estágios de maturidade da gestão logística (MGL) e estágios do ciclo de vida organizacional (CVO).

De acordo com o resultado do teste Qui-quadrado, há evidências estatísticas para afirmar que existe associação não aleatória entre os estágios de desenvolvimento dos dois modelos teóricos. Portanto, os gestores devem também considerar os construtos abordados no modelo de CVO para avançar no estágio de MGL e vice-versa.

A fim de responder às hipóteses específicas de H1, prosseguiu-se com a segunda etapa da ANACOR: a construção do mapa perceptual. Foram, então, construídas as tabelas de perfis das linhas e colunas da amostra, em que as linhas representam os estágios de MGL e as colunas, os do CVO.

A tabela de perfis das linhas indica a proporção das linhas para cada célula da tabela de contingência (FÁVERO et al, 2009, p. 287). Conforme exibido na Tabela 18, das empresas do estágio Fundação, 31,6\% foram classificadas como Existência, 10,5\% como Sobrevivência, e assim sucessivamente. A massa é o valor que indica a influência de cada estágio do CVO sobre os de MGL, e pode variar de 0 a 1. Por exemplo, o estágio Reativação possui mais influência que os demais $(0,357)$, pois foi o estágio com maior número de casos observados.

Tabela 18 - Perfis das linhas

\begin{tabular}{|l|c|c|c|c|c|}
\hline \multicolumn{1}{|c|}{ MGL / CVO } & EXISTÊNCIA & SOBREVIVÊNCIA & SUCESSO & REATIVAÇÃO & DECLÍNIO \\
\hline FUNDAÇÃO & 0,316 & 0,105 & 0,105 & 0,105 & 0,368 \\
\hline ESTRUTURA & 0,545 & 0,061 & 0,121 & 0,121 & 0,152 \\
\hline VISÃO & 0,286 & 0,167 & 0,095 & 0,310 & 0,143 \\
\hline INTEGRAÇ̃̃̃O & 0,138 & 0,241 & 0,138 & 0,397 & 0,086 \\
\hline DINÂMICA & 0,082 & 0,213 & 0,115 & 0,557 & 0,033 \\
\hline MASSA & $\mathbf{0 , 2 3 0}$ & $\mathbf{0 , 1 7 8}$ & $\mathbf{0 , 1 1 7}$ & $\mathbf{0 , 3 5 7}$ & $\mathbf{0 , 1 1 7}$ \\
\hline
\end{tabular}


A tabela de perfis das colunas, por sua vez, indica a influência de cada estágio de MGL nos estágios de CVO. Na Tabela 19, pode ser observado que, das empresas classificadas como Existência, 12,2\% estão no estágio Fundação, 36,7\% no Estrutura, e assim por diante. De maneira análoga, a massa representa a influência de cada estágio de MGL nos do CVO. Dessa forma, o estágio Dinâmica foi o que exerceu maior influencia, com 28,6\%, pois nele houve o maior número de classificações.

Tabela 19 - Perfis das colunas

\begin{tabular}{|l|c|c|c|c|c|c|}
\hline \multicolumn{1}{|c|}{ MGL / CVO } & EXISTÊNCIA & SOBREVIVÊNCIA & SUCESSO & REATIVAÇÃO & DECLÍNIO & Massa \\
\hline FUNDAÇÃO & 0,122 & 0,053 & 0,080 & 0,026 & 0,280 & $\mathbf{0 , 0 8 9}$ \\
\hline ESTRUTURA & 0,367 & 0,053 & 0,160 & 0,053 & 0,200 & $\mathbf{0 , 1 5 5}$ \\
\hline VISÃO & 0,245 & 0,184 & 0,160 & 0,171 & 0,240 & $\mathbf{0 , 1 9 7}$ \\
\hline INTEGRAÇÃO & 0,163 & 0,368 & 0,320 & 0,303 & 0,200 & $\mathbf{0 , 2 7 2}$ \\
\hline DINÂMICA & 0,102 & 0,342 & 0,280 & 0,447 & 0,080 & $\mathbf{0 , 2 8 6}$ \\
\hline
\end{tabular}

Em seguida, foram calculados os valores singulares e a inércia. Essas medidas correspondem às correlações entre os escores em linha ou em coluna para cada dimensão (Fávero et al, 2009, p. 288). Os valores singulares e a inércia são importantes para determinar o número de dimensões do mapa perceptual, baseado na variância explicada e na explicação extra, ganha por cada dimensão adicional. Lembrando que o número máximo de dimensões é igual o número máximo entre linhas e colunas, menos um, nesse caso, portanto, igual a quatro.

Conforme pode ser visto na coluna Proporção da Inércia Individual (Tabela 20), a Dimensão 1 explica 84,3\% das associações, a segunda Dimensão, 13,4\%, e as Dimensões 2 e 3, juntas, explicam apenas 0,023\%. Na coluna de Proporção de Inércia Acumulado, observa-se que as Dimensões 1 e 2, juntas, explicam 97,7\% das associações. Deste modo, decidiu-se trabalhar com apenas duas dimensões (MGL e CVO), sendo que a primeira é explica a maior parte do comportamento dos dados.

Tabela 20 - Inércia e autovalor

\begin{tabular}{|c|c|c|c|c|c|c|c|c|c|c|}
\hline \multirow{2}{*}{ Dimensão } & \multirow{2}{*}{$\begin{array}{c}\text { Valor } \\
\text { Singular }\end{array}$} & \multirow{2}{*}{ Inércia } & \multirow{2}{*}{$\begin{array}{c}\text { Qui } \\
\text { Quadrado }\end{array}$} & \multirow{2}{*}{ Sig. } & \multicolumn{2}{|c|}{ Proporção da Inércia } & \multicolumn{3}{|c|}{ Valor singular de confiança } \\
\cline { 6 - 11 } & & & & Individual & Acumulado & \multicolumn{2}{|c|}{$\begin{array}{c}\text { Desvio } \\
\text { Padrão }\end{array}$} & \multicolumn{3}{|c|}{ Correlação } \\
\hline 1 & 0,485 & 0,236 & & & 0,843 & 0,843 & 0,057 & 0,123 & 0,097 & $-0,085$ \\
\hline 2 & 0,194 & 0,037 & & & 0,134 & 0,977 & 0,094 & & 0,063 & $-0,011$ \\
\hline 3 & 0,074 & 0,006 & & & 0,020 & 0,997 & 0,074 & & & $-0,005$ \\
\hline 4 & 0,031 & 0,001 & & & 0,003 & 1,000 & 0,064 & & & \\
\hline Total & & $\mathbf{0 , 2 8 0}$ & $\mathbf{5 9 , 5 4}$ & $\mathbf{0 , 0 0}$ & $\mathbf{1 , 0 0 0}$ & $\mathbf{1 , 0 0 0}$ & & & & \\
\hline
\end{tabular}


Depois de definido o número de dimensões e calculados os seus respectivos valores singulares e inércia, o passo seguinte para a construção do mapa perceptual foi calcular o valor dos escores de cada elemento das linhas e colunas, bem como as suas contribuições à inércia em cada dimensão.

Os escores nada mais são do que as coordenadas dos pontos linhas e pontos colunas na representação espacial e a inércia representa a capacidade explicativa desses pontos em cada dimensão (FÁVERO et al, 2009, p. 289). Os autores explicam que a contribuição do ponto à inercia da dimensão depende da massa e da distância a partir da origem (0;0). Dessa forma, quanto maior a massa e mais afastado da origem estiver um ponto maior será a sua contribuição para a inércia de cada dimensão.

Conforme pode ser observado na coluna Contribuição do ponto de inércia da Dimensão (Tabela 21), os estágios Estrutura e Dinâmica foram dominantes na Dimensão 1, com 38,6\% e $32,6 \%$ da inércia total, respectivamente, enquanto que o estágio Fundação foi o dominante na Dimensão 2, com 59,9\% de contribuição. A coluna Escore na Dimensão representa o ponto em que cada estágio de MGL será localizado no plano cartesiano, por exemplo, o estágio Fundação será no ponto $(-1,037 ;-1,140)$.

Tabela 21 - Escores das linhas

\begin{tabular}{|c|c|c|c|c|c|c|c|c|c|}
\hline \multirow[b]{3}{*}{ MGL } & \multirow[b]{3}{*}{ Massa } & \multicolumn{2}{|c|}{ Escore na Dimensão } & \multirow[b]{3}{*}{ Inércia } & \multicolumn{5}{|c|}{ Contribuição } \\
\hline & & & & & \multicolumn{2}{|c|}{$\begin{array}{c}\text { Do Ponto de Inércia } \\
\text { da Dimensão }\end{array}$} & \multicolumn{3}{|c|}{$\begin{array}{c}\text { Da Dimensão } \\
\text { para Inércia do Ponto }\end{array}$} \\
\hline & & 1 & 2 & & 1 & 2 & 1 & 2 & Total \\
\hline FUNDAÇÃO & 0,089 & $-1,037$ & $-1,140$ & 0,069 & 0,198 & 0,599 & 0,672 & 0,323 & 0,995 \\
\hline ESTRUTURA & 0,155 & $-1,099$ & 0,677 & 0,105 & 0,386 & 0,367 & 0,868 & 0,131 & 0,999 \\
\hline VISÃO & 0,197 & $-0,231$ & 0,001 & 0,006 & 0,022 & 0,000 & 0,859 & 0,000 & 0,859 \\
\hline INTEGRAÇÃO & 0,272 & 0,352 & $-0,118$ & 0,021 & 0,069 & 0,020 & 0,795 & 0,036 & 0,831 \\
\hline DINÂMICA & 0,286 & 0,743 & 0,100 & 0,079 & 0,326 & 0,015 & 0,971 & 0,007 & 0,978 \\
\hline Total & $\mathbf{1 , 0 0 0}$ & & & 0,280 & 1,000 & 1,000 & & & \\
\hline
\end{tabular}

Já a Tabela 22 exibe as coordenadas dos estágios do CVO. Pode-se observar na coluna de Contribuição do ponto para a inércia da dimensão, que na Dimensão 1 os estágios que mais contribuem são Existência (41,5\%) e Reativação (30,8\%), enquanto que na Dimensão 2 o estágio Declínio é a categoria dominante, representando 64\% da inércia total. A coluna Escore 
na Dimensão representa o ponto em que cada estágio do CVO está localizado no plano cartesiano, assim, o estágio Existência está no ponto $(-0,936 ; 0,519)$.

Tabela 22 Escores das colunas

\begin{tabular}{|c|c|c|c|c|c|c|c|c|c|}
\hline \multirow{3}{*}{$\mathrm{CVO}$} & \multirow{3}{*}{ Massa } & \multicolumn{2}{|c|}{ Escore na Dimensão } & \multirow{3}{*}{ Inércia } & \multicolumn{5}{|c|}{ Contribuição } \\
\hline & & \multirow[t]{2}{*}{1} & \multirow[t]{2}{*}{2} & & \multicolumn{2}{|c|}{$\begin{array}{l}\text { Do Ponto de Inércia } \\
\text { da Dimensão }\end{array}$} & \multicolumn{3}{|c|}{$\begin{array}{c}\text { Da Dimensão } \\
\text { para Inércia do Ponto }\end{array}$} \\
\hline & & & & & 1 & 2 & 1 & 2 & Total \\
\hline EXISTÊNCIA & 0,230 & $-0,936$ & 0,519 & 0,110 & 0,415 & 0,320 & 0,890 & 0,109 & 1,000 \\
\hline SOBREVIVÊNCIA & 0,178 & 0,471 & $-0,173$ & 0,023 & 0,081 & 0,027 & 0,840 & 0,045 & 0,885 \\
\hline SUCESSO & 0,117 & 0,051 & 0,039 & 0,002 & 0,001 & 0,001 & 0,075 & 0,018 & 0,093 \\
\hline REATIVAÇÃO & 0,357 & 0,647 & 0,077 & 0,075 & 0,308 & 0,011 & 0,971 & 0,005 & 0,976 \\
\hline DECLÍNIO & 0,117 & $-0,898$ & $-1,028$ & 0,070 & 0,195 & 0,640 & 0,655 & 0,342 & 0,996 \\
\hline Total & 1,000 & & & 0,280 & 1,000 & 1,000 & & & \\
\hline
\end{tabular}

Uma vez determinada as coordenadas de cada um dos estágios de MGL e CVO, o SPSS as reproduz em um plano cartesiano para as duas categorias, conforme Ilustrações 3 e 4.

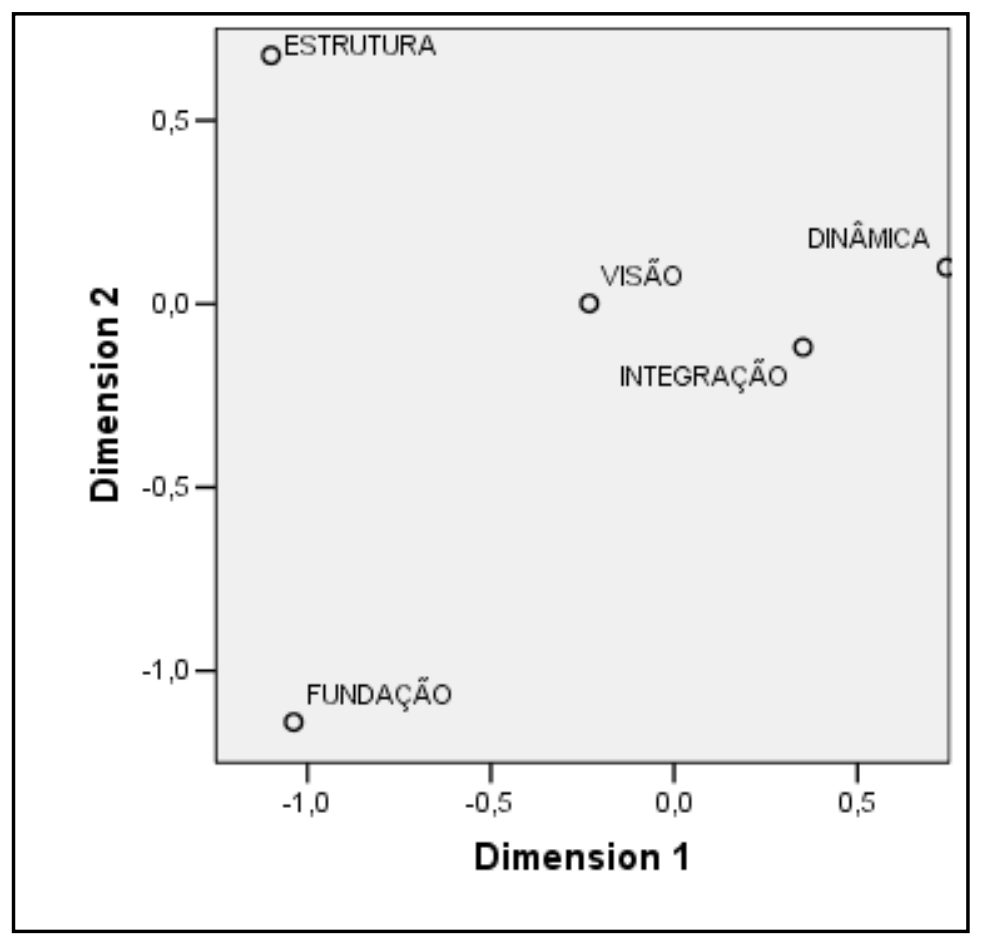

Ilustração 3 - Mapa perceptual para MGL 


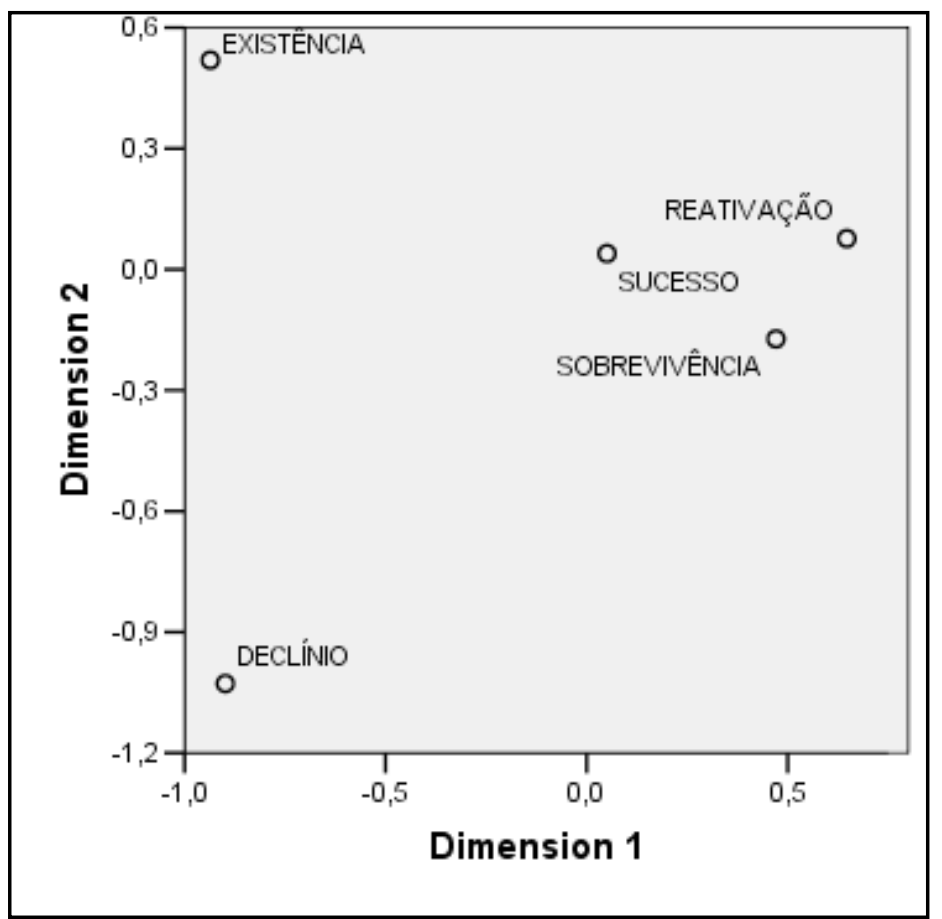

Ilustração 4 - Mapa perceptual para CVO

Finalmente, a representação gráfica conjunta dos estágios de MGL e CVO pode ser observada na Ilustração 5.

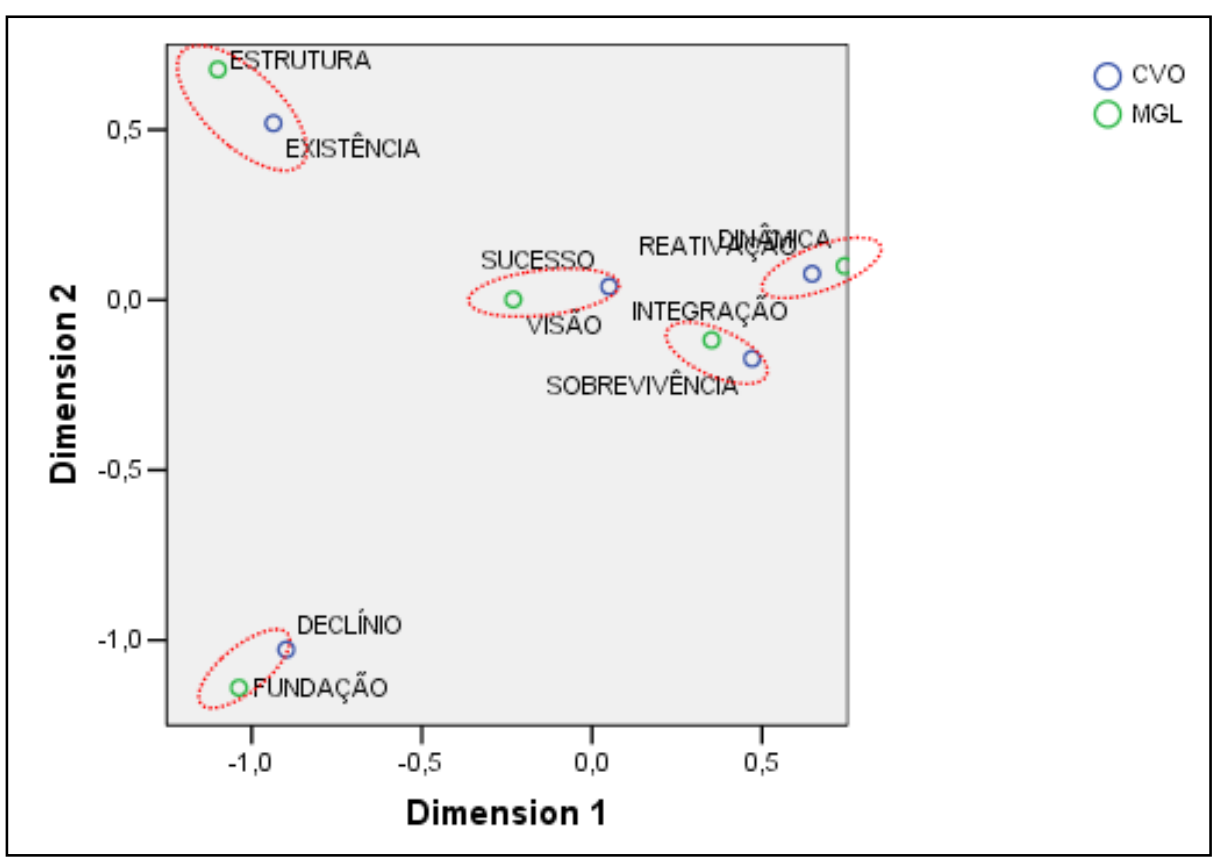

Ilustração 5 - Mapa perceptual para MGL e CVO 
Com base nesse mapa perceptual, é possível identificar graficamente as associações entre os estágios de maturidade da gestão logística e do ciclo de vida organizacional, obtendo subsídios para responder às hipóteses específicas de H1.

H1 $1_{\mathrm{A}}$ : Empresas classificadas como Fundação no modelo de MGL serão classificadas como Existência no modelo de CVO.

A hipótese $\mathbf{H 1}_{\mathbf{A}}$ não foi aceita, pois as empresas classificadas no estágio Fundação de MGL estão associadas com o estágio de Declínio do CVO, conforme indica a proximidade de seus respectivos pontos no mapa perceptual (Ilustração 5).

Oliveira (2009, p. 111) explica que o estágio Fundação é caracterizado pela construção de uma estrutura básica e tem como objetivo evitar procedimentos contingenciais e reações desordenadas. Lester et al (2003, p. 343) comentam que o estágio Declínio é caracterizado pela incapacidade de atender as demandas externas e leva a uma experiência de perda de participação de mercado e ausência de lucros. Dessa forma, é coerente afirmar que as empresas devem superar rapidamente o estágio Fundação de MGL, sob o risco de entrarem no estágio de Declínio no CVO, que poderá levá-las à extinção.

H1 $1_{\mathbf{B}}$ : Empresas classificadas como Estrutura no modelo de MGL serão classificadas como Sobrevivência no modelo de CVO.

Também não se pode aceitar a hipótese específica de $\mathrm{H} 1_{\mathrm{B}}$, pois o estágio Estrutura de MGL não está associado ao estágio Sobrevivência de CVO - conforme percebido pela distância entre esses pontos no mapa perceptual (Ilustração 5) - situando-se mais próximo do estágio Existência (CVO).

Segundo Oliveira (2009, p. 112), no estágio Estrutura de MGL os processos da empresa começam a ser estruturados para, posteriormente, serem integrados. Enquanto que Lester et al (2003, p. 342) explicam que o estágio Existência do CVO marca o começo do desenvolvimento organizacional e da viabilização da empresa, ou simplesmente, a identificação de um grupo suficientemente grande de clientes para garantir a existência da organização. Portanto, pode-se concluir que, para que uma empresa configure no primeiro 
estágio do CVO, em que o objetivo é conquistar o maior número de clientes, deve, pelo menos, entrar no segundo estágio da MGL.

H1 $1_{C}$ : Empresas classificadas como Visão ou Integração no modelo de MGL serão classificadas como Sucesso no modelo de CVO.

A hipótese específica $\mathrm{H} 1_{\mathrm{C}}$ pode ser apenas parcialmente aceita. No mapa perceptual (Ilustração 5), o estágio Visão está próximo do estágio Sucesso, porém, o estágio Integração está mais próximo do Sobrevivência.

No estágio Visão de MGL, segundo Oliveira (2009, p. 113), os processos passam a ter donos, os quais são responsáveis por sua gestão e desempenho, enquanto que, o estágio Sucesso do CVO, tem como característica uma estrutura organizacional mais formalizada e maior controle burocrático (LESTER et al, 2003, p. 343). De acordo com as teorias, tanto no estágio Visão de MGL, quanto no estágio Sucesso do CVO, a governança dos processos representa o principal objetivo, portanto, há subsídios para explicar a existência de associação entre esses estágios.

A associação entre o estágio Integração de MGL, com o Sobrevivência do CVO, não era esperada. Entretanto, é possível as teorias apresentam algumas similaridades nas descrições desses dois estágios, que permitem justificar essa associação não prevista.

No modelo de MGL, Oliveira (2009, p. 114) explica que, no estágio Integração, as previsões passam a ser desenvolvidas em maior nível de detalhe e que a equipe de planejamento estratégico avalia a lucratividade de cada cliente e produto individualmente. Enquanto que no modelo de CVO, Lester et al (2003, p. 342) explicam que, a maioria das organizações do estágio Sobrevivência já consegue analisar de alguma forma o ambiente externo, e o objetivo principal nesse estágio é gerar receitas suficientes para continuar as operações e financiar o crescimento para manter-se competitivo.

De acordo com a teoria do CVO, quando a organização atinge o estágio Sobrevivência, a meta principal é gerar receitas e lucros. Algumas empresas que estão neste estágio conseguem atingir esse objetivo, e entram no estágio três (Sucesso), outras não irão conseguir gerar retornos suficientes para sobreviverem (LESTER et al, 2003, p. 342). Essa pressão para obter 
lucro faz com que a empresa busque colaboração com os parceiros da cadeia, que é uma característica presente no estágio Integração de MGL, segundo Oliveira (2009, p. 114).

H1 D: Empresas classificadas como Dinâmica no modelo de MGL serão classificadas como Reativação no modelo de CVO.

Já a hipótese específica $\mathrm{H} 1_{\mathrm{D}}$ foi totalmente aceita. Conforme o mapa perceptual (Ilustração 5), os estágios Dinâmica de MGL, e Reativação do CVO, estão próximos um do outro.

Para Oliveira (2009, p. 115) as empresas que se encontram no estágio Dinâmica, possuem uma integração sistêmica e estratégica da cadeia, tendo como principal característica o relacionamento próximo com os clientes e atendimento às suas demandas de curto prazo. Já as empresas que se encontram no estágio Reativação do CVO, segundo Lester et al (2003, p. 343), as necessidades dos clientes são colocadas acima das necessidades dos membros da organização. Portanto, essas similaridades encontradas na teoria quanto às prioridades justifica a existência de tal associação.

Portanto, após a classificação das empresas de acordo com os modelos teóricos de MGL e CVO e análise da associação entre os estágios de desenvolvimento com utilização da ANACOR, pode-se considerar que o objetivo principal dessa dissertação foi cumprido satisfatoriamente, ou seja, verificou-se que há associação entre os estágios de desenvolvimento dos dois modelos, sendo que as associações observadas seguem conforme quadro 15.

Quadro 15 - Associação entre os estágios de MGL e C
\begin{tabular}{|rc|}
\hline MGL $\leftrightarrow$ CVO \\
\hline FUNDAÇÃO $\leftrightarrow$ DECLÍNIO \\
ESTRUTURA $\leftrightarrow$ EXISTÊNCIA \\
VISÃO $\leftrightarrow$ SUCESSO \\
INTEGRAÇÃO $\leftrightarrow$ SOBREVIVÊNCIA \\
DINÂMICA & $\leftrightarrow$ REATIVAÇÃO \\
\hline
\end{tabular}

Pode-se concluir, ainda, que as associações entre o estágio Fundação com o Declínio, e entre o Estrutura com o Existência, são as mais significativas e possuem maior poder explicativo, uma vez que estes se encontram nos pontos mais afastados da origem. 


\subsection{Utilização de artefatos de controle gerencial}

Para verificar a intensidade da utilização de artefatos de controle gerencial pelas empresas, o formulário eletrônico continha sete questões, sobre a utilização de determinados artefatos na prática de gestão da organização (Apêndice 7). Os respondentes assinalaram "Sim”, caso o artefato fosse utilizado pela empresa ou "Não", caso contrário.

Os artefatos selecionados para essa dissertação - Supplier Scorecard, ABC, PNI, GCI, Custeio alvo, Análise de custo para servir e Análise de custo total - tiveram sua eficácia testada e comprovada por estudos anteriores (BRAITHWAITE; SAMAKH, 1998; COOPER; SLAGMULDER, 2003a; COOPER; SLAGMULDER, 2003b; TRENT, 2010; WANG et al, 2010; COMELLIA et al, 2008; MUZUMDAR; VISWANATHAN, 2009;).

O primeiro artefato investigado foi o Supplier scorecard. Segundo Trent (2010, p. 24), mesmo as organizações que possuem um sistema maduro de métricas de fornecedores devem reconhecer que a melhoria contínua é um desafio constante. Para ser eficaz, o sistema de avaliação de fornecedores deve ser flexível e considerar a importância de cada fornecedor individualmente.

A segunda questão versava sobre o ABC, Custeio Baseado em Atividade. Segundo Wang et al (2010, p. 39), a utilização desse artefato ajuda a encontrar oportunidades de melhoria na eficiência da gestão da cadeia logística e contribui para reduzir os custos de operação. Para Comellia et al (2008), a utilização do ABC aumenta a visibilidade dos custos das atividades.

O terceiro artefato foi o PNI, Plano de Negócio Integrado. Segundo Muzumdar e Viswanathan (2009, p. 40), esse artefato ajuda as organizações a tomarem ações corretivas na cadeia de forma mais eficiente, visto que ajuda a entender a raiz dos problemas. Essa ferramenta pode ser adotada a qualquer tempo no ciclo de vida da organização, durante recessão ou expansão (MUZUMDAR; VISWANATHAN, 2009, p. 36).

A GCI, Gestão de Custos Interorganizacional, foi o quarto artefato abordado. Segundo Cooper e Slagmulder (2003a, p. 14), a GCI torna a cadeia de suprimentos mais eficiente e aumenta a 
lucratividade total. Outro artefato de controle gerencial pode ocorrer concomitantemente à GCI: o Custeio Alvo (COOPER; SLAGMULDER, 2003b, p. 12).

Dessa forma, o quinto artefato foi o Custeio alvo. Para Ansari et al (2007, p. 507) o custeio alvo é um sistema de planejamento de lucro e gestão de custos que garante que os novos produtos e serviços atendam aos preços e retornos determinados pelo mercado.

O sexto artefato pesquisado foi a Análise do Custo para Servir. Braithwaite e Samakh (1998, p. 70) afirmam que essa ferramenta de controle gerencial pode fornecer informações que facilitam a integração da cadeia de valor. Guerreiro et al (2008) constataram que a mensuração do custo para servir os clientes fornece informações importantes e detalhadas sobre a análise de lucratividade por cliente.

Finalmente, o sétimo artefato foi a Análise de Custo Logístico Total. Lambert e Burduroglu (2010, p. 7) explicam que, devido à natureza complexa (inter-relacionada) do processo logístico, é preciso considerar que a redução de custo em uma atividade específica pode resultar em aumento em outra ponta do processo. Bowersox et al (2010, p. 317) afirmam que a identificação da estrutura de custo total mínimo é o objetivo da integração logística.

As empresas poderiam responder que utilizam todos ou nenhum dos artefatos mencionados. Primeiramente, buscou-se conhecer quais os artefatos mais utilizados. A Tabela 23 indica a quantidade de empresas que declararam usarem cada um dos artefatos supracitados.

Tabela 23 - Quantidade de empresas que declaram utilizar cada artefato

\begin{tabular}{|l|c|c|}
\hline \multicolumn{1}{|c|}{ Artefato } & Quantidade & \% \\
\hline Análise de custo total & 170 & 79,8 \\
\hline Custo para servir & 147 & 69,0 \\
\hline Supplier Scorecard & 126 & 59,2 \\
\hline ABC & 112 & 52,6 \\
\hline Custeio alvo & 106 & 49,8 \\
\hline Plano negócio integrado & 103 & 48,4 \\
\hline GCI & 60 & 28,2 \\
\hline
\end{tabular}

Chama a atenção, a quantidade de empresas que declararam utilizar a Análise de custo total (79,8\%). Esse resultado contrasta com os encontrados por Fellous (2009), que aprontou que a maior parte das empresas pesquisadas não utiliza esse artefato. Dessa forma, essa questão 
precisa ser investigada com maior profundidade, dado a divergência com relação ao estudo anterior.

Por outro lado, apenas 28,2\% das empresas pesquisadas declararam que utilizam a GCI. Esse resultado confirma que as empresas pesquisadas desenvolvem poucos os relacionamentos colaborativos, com os parceiros da cadeia de suprimentos. Conforme discutido anteriormente, no modelo de MGL, o construto C-09 (Integração com clientes), C-10 (Gestão da rede de fornecedores), e C-11 (Comportamento estratégico), foram os que obtiveram os menores percentuais de atribuição de escores.

Entretanto, objetivo neste ponto da pesquisa foi o de buscar subsídios que possam ajudar a aceitar ou refutar a segunda hipótese:

H2: Empresas classificadas em estágios mais avançados do modelo de MGL e do CVO utilizam maior quantidade de artefatos de controle gerencial.

Para esse propósito, calculou-se, em cada estágio do modelo de MGL, a média da quantidade de artefatos que os respondentes declararam utilizar. Na Tabela 24 pode-se observar que as maiores médias, correspondem aos estágios mais avançados de MGL. Por exemplo, as empresas classificadas no primeiro estágio, Fundação, utilizam, em média, 1,3 artefatos de um total de sete. As empresas do quinto estágio, Dinâmica, utilizam em média 5,5.

Tabela 24 - Quantidade média de artefatos utilizada por estágio de MGL

\begin{tabular}{|l|r|}
\hline Estágios de MGL & \multicolumn{1}{c|}{ Total } \\
\hline DINÂMICA & 5,5 \\
\hline INTEGRAÇÃO & 4,7 \\
\hline VISÃO & 3,2 \\
\hline ESTRUTURA & 1,8 \\
\hline FUNDAÇÃO & 1,3 \\
\hline Média & $\mathbf{3 , 9}$ \\
\hline
\end{tabular}

Para testar a significância estatística dessa associação, realizou-se o teste de média KruskalWallis. Conforme Quadro 16, há evidências estatísticas ao nível de significância de 5\% para não aceitar a hipótese nula, de independência entre os grupos. Portanto, pode-se concluir que a utilização de artefatos está relacionada ao estágio de MGL. 
Quadro 16 - Teste de média entre o estágio de MGL da empresa e a utilização de artefatos

\begin{tabular}{|l|r|}
\hline Teste Estatístico (a,b) & Artefatos \\
\hline Qui-quadrado & 109,830 \\
Sig. & 0,000 \\
\hline \multicolumn{2}{|l}{ a Teste Kruskal Wallis } \\
b Variável testada: MGL
\end{tabular}

Na Tabela 25 é demonstrada a quantidade média de artefatos de controle gerencial por estágio do CVO. Nessa análise, constatou-se que as empresas classificadas no estágio mais avançado, Reativação, possuem a maior média de utilização de artefatos. A segunda maior média foi a do estágio Sobrevivência. Observa-se, também, que as empresas classificadas no estágio Declínio possuem a menor média de utilização de artefatos de gestão, com quantidade média de utilização de apenas 2,1 artefatos.

Tabela 25 - Quantidade média de artefatos utilizados por estágio de CVO

\begin{tabular}{|c|c|}
\hline \multicolumn{2}{|c|}{ Média de Artefatos por estágios } \\
\hline Estágios de CVO & Total \\
\hline REATIVAÇÃO & 4,9 \\
\hline SOBREVIVÊNCIA & 4,6 \\
\hline SUCESSO & 4,0 \\
\hline EXISTÊNCIA & 2,6 \\
\hline DECLÍNIO & 2,1 \\
\hline Total Geral & $\mathbf{3 , 9}$ \\
\hline
\end{tabular}

Esperava-se que no estágio Sucesso as empresas utilizassem mais artefatos do que no Sobrevivência. No entanto, Lester et al (2003, p. 342) explicam que o estágio Sobrevivência é crucial para as organizações, pois aquelas que conseguem atingir as margens suficientes para se manterem competitivas entram no estágio três (Sucesso), enquanto que as que não alcançarem essa meta terão o futuro seriamente comprometido. Talvez, essa pressão pelo crescimento justifica o fato de que há maior utilização de artefatos no estágio de Sobrevivência do que no Sucesso.

Para verificar a significância estatística dessas associações, novamente se recorreu ao teste de Kruskal-Wallis. Conforme Quadro 17, não há evidencias para aceitar a hipótese nula do teste, ou seja, há diferenças significativas entre as médias de utilização de artefatos de controle gerencial e o estágio atual do CVO. 
Quadro 17 - Teste de média entre estágio de CVO e utilização de artefatos

\begin{tabular}{l|r|}
\hline Teste Estatístico (a,b) & Artefatos \\
\hline Qui-quadrado & 54,772 \\
Sig. & 0,000 \\
\hline
\end{tabular}

Em resposta à segunda hipótese $(\mathbf{H 2})$, constatou-se que quanto mais avançado é o estágio de MGL das empresas, maior é a quantidade média de artefatos de controle gerencial utilizados. Para os estágios do CVO, também se constatou a existência de associação com a média de utilização de artefatos. Contudo, os estágios com maior média de utilização de artefatos são Reativação e Sobrevivência e os estágios Existência e Declínio tiveram as menores médias.

Verificou-se, também, se a quantidade média de artefatos utilizados pelas empresas tem relação com o seu porte. Constatou-se que as de Grande porte são as que possuem a maior média, 4,3. Em seguida, encontram-se as Microempresas, ou seja, àquelas com menos de 20 funcionários, com média 3,29. Médias e Pequenas empresas tiveram média de 3,24 e 3,22, respectivamente, conforme pode ser observado na Tabela 26.

Tabela 26 - Quantidade média de artefatos por porte de empresa

\begin{tabular}{|l|l|r|}
\hline \multicolumn{3}{|c|}{ Média de artefatos por porte da empresa } \\
\hline Empregados & \multicolumn{1}{|c|}{ Porte } & Média \\
\hline Mais de 500 & Grande & 4,35 \\
Menos de 20 & Microempresa & 3,29 \\
entre 100 e 499 & Média & 3,24 \\
entre 20 e 99 & Pequena & 3,22 \\
\hline
\end{tabular}

A análise superficial da Tabela 26 não permite concluir se há associação significante entre o porte da empresa e a quantidade média de utilização de artefatos de controle gerencial. Para testar a significância estatística dessa associação realizou-se o teste de Kruskal-Wallis (Quadro 18).

Quadro 18 - Teste de média entre porte da empresa e utilização de artefatos

\begin{tabular}{l|r|}
\hline Teste Estatístico (a,b) & Artefatos \\
\hline Qui-quadrado & 13,504 \\
Sig. & 0,004 \\
\hline a Teste Kruskal Wallis \\
b Variável testada: PORTE
\end{tabular}


Conforme demonstra o resultado do Quadro 18, há evidências estatísticas para assumir que existe uma associação não aleatória entre porte da empresa e a quantidade média de artefatos utilizados, ou seja, o porte é significante para determinar a quantidade média de artefatos que as empresas utilizam como ferramenta de gestão.

No entanto, foi realizado um teste estatístico adicional somente com as empresas das categorias de porte: Média, Pequena e Microempresa. Constatou-se que, entre esses três grupos, não há diferença significativa na média de artefatos utilizados. Dessa forma, concluiuse a quantidade média de artefatos é diferenciada somente para as empresas de grande porte.

Analisou-se também se havia divergências significativas na utilização de artefatos de controle gerencial em função do tempo de existência das empresas. As empresas com mais de 30 anos foram àquelas que apresentaram a maior média de artefatos utilizados, 4,01. Dentre as empresas com mais de 20 e menos do que 30 anos, essa média foi de 4,0 e para as empresas mais jovens (com menos de 10 anos), a média foi de 3,91 artefatos. $\mathrm{O}$ grupo de empresas que possuem entre 10 e 20 anos foi o que obteve a menor média de utilização, 3,24 (Tabela 27).

Tabela 27 - Quantidade média de artefatos por idade da empresa

\begin{tabular}{|l|c|}
\hline \multicolumn{2}{|c|}{ Média de artefatos por idade da empresa } \\
\hline \multicolumn{1}{|c|}{ Idade } & \multicolumn{1}{c|}{ Média } \\
\hline Maior do que 30 anos & 4,01 \\
Entre 20 e 30 anos & 4,00 \\
Menor do que 10 anos & 3,91 \\
Entre 10 e 20 anos & 3,24 \\
\hline
\end{tabular}

Novamente, não é possível fazer inferências sobre a significância das associações, a partir da análise superficial da Tabela 27. Realizou-se, portanto, o teste estatístico Kruskal-Wallis, para verificar a significância estatística dessa associação entre a idade da empresa e a média de artefatos utilizados.

Quadro 19 - Teste de média entre idade da empresa e utilização de artefatos

\begin{tabular}{|l|r|}
\hline Teste Estatístico (a,b) & Artefatos \\
\hline Qui-quadrado & 3,172 \\
Sig. &, 529 \\
\hline
\end{tabular}

b Variável testada: IDADE

Conforme demonstra o resultado do Quadro 19, com 95\% de confiança, pode-se assumir que não há diferenças significativas na média de utilização de artefatos de controle gerencial de 
acordo com a idade das empresas. Dessa forma, pode-se concluir que o tempo de vida da empresa não é determinante para influenciar a quantidade média de artefatos utilizados como ferramenta de gestão.

Essas análises permitiram concluir que a quantidade de artefatos de controle gerencial utilizado pelas empresas não depende de sua idade, mas o seu porte pode ser significante para determiná-la. Também se constatou que as empresas que utilizam maior quantidade média de artefatos estão classificadas nos estágios mais avançados do modelo de MGL.

Quanto a relação com os estágios do CVO, constatou-se que as empresas que estão classificadas nos estágios Reativação e Sobrevivência são aquelas que utilizam maior quantidade de artefatos. Essa associação se justifica pelo fato de que esses são os estágios mais agressivos do modelo, em termos de busca por competitividade. 


\section{CONSIDERAÇÕES FINAIS E RECOMENDAÇÕES}

Os modelos de maturidade oferecem uma maneira de traçar um caminho para melhorar os processos em níveis de maturidade distintos (OLIVEIRA, 2009, p. 17). No modelo aplicado nesta dissertação, a maturidade da gestão logística (MGL) é determinada pela configuração de competências observadas no fluxo normal dessa atividade.

As organizações crescem ao expandir o seu portfólio de produtos ou serviços para atender mercados mais maduros e, nesse processo, enfrentam maior heterogeneidade de clientes e mercados mais hostis (MOORES; YUEN, 2001, p. 353). A capacidade de uma organização enfrentar e gerenciar essas novas contingências define o seu estágio atual no ciclo de vida.

Compreender o estágio atual do ciclo de vida organizacional (CVO) contribui para os gestores desenvolverem estratégias e permite identificar as mudanças que devem ocorrer quando a organização cresce e se desenvolve (LESTER et al, 2003, p. 340). Dessa forma, os gestores devem considerar também que o desenvolvimento da MGL requer que a organização esteja preparada para suportar o aumento do nível de complexidade da gestão logística.

Nesse sentido, a principal contribuição desta dissertação foi a comprovação empírica de que existe associação entre os estágios dos modelos de MGL e CVO. Esse achado corrobora com a visão de Bertalanffy (1977) de que existe um ponto comum entre os modelos teórico (teorias), a qual o autor convencionou chamar de Teoria Geral dos Sistemas, ou seja, as decisões devem considerar múltiplas variáveis que impactam o resultado desejado direta ou indiretamente. Também se constatou na pesquisa empírica que as empresas em estágios mais desenvolvidos de maturidade da gestão logística utilizam mais artefatos de controle gerencial.

Os gestores muitas vezes falham ao não perceber que soluções para um problema imediato pode trazer problemas futuros à organização (GREINER, 1972). Dessa forma, a implantação de um projeto para desenvolver a MGL deve envolver toda a empresa para garantir o envolvimento dos gestores e, principalmente, que a organização está apta para iniciar uma nova fase em seu ciclo de desenvolvimento. 
A operacionalização da pesquisa realizou-se com utilização de um formulário eletrônico com questões acerca do modelo de gestão logística da empresa, da situação organizacional e da utilização de determinados artefatos de controle gerencial. O público-alvo foram gestores de logística, que tivessem conhecimentos tanto da gestão logística quanto da gestão organizacional. A amostra final constituiu-se de 213 respostas válidas.

Dessa amostra, 65\% exerciam função de gerente, diretor ou presidente das organizações, sendo que, a maioria desses profissionais (69\%) atuam nas áreas de gestão logística: distribuição, produção, suprimentos e gestão logística interna e externa.

Quanto ao perfil das organizações investigadas, constatou-se que 67\% tem mais de 30 anos de existência e 56\% são empresas de grande porte, com mais de 500 empregados. Segundo Miller e Friesen (1984, p. 1178), cada ciclo de vida da organização deve durar aproximadamente dez anos. Dessa forma, ao classificar as organizações de acordo com o modelo de CVO, era esperado que os estágios mais avançados tivessem maior concentração de empresas, e foi isso que aconteceu.

Assim, de uma forma resumida, o perfil geral dos participantes dessa dissertação pode ser descrito da seguinte maneira: "profissionais das principais áreas de gestão logística com cargos de liderança, em empresas de grande porte e com mais de 30 anos de existência".

Dentre as análises realizadas nessa dissertação, investigou-se a relação entre o perfil da empresa e sua classificação nos estágios de maturidade da gestão logística. Constatou-se não haver associação entre estágios de MGL com perfil das empresas. Dessa forma, a classificação das empresas nos estágios de MGL depende das competências presentes na gestão logística, mas não do porte e idade dessas empresas. O modelo propõe a classificação das empresas em estágios de desenvolvimento, de acordo com os escores obtidos em 13 construtos (competências).

Sobre o padrão de respostas dos participantes nos construtos do modelo de MGL, constatouse que as competências Gestão e controle de pedidos dos clientes (C-02) e Construção da fundação (C-01) foram aquelas para as quais os respondentes atribuíram os maiores escores. Por outro lado, as competências Integração com o cliente (C-09) e Comportamento estratégico (C-11), foram as que obtiveram as menores atribuições de escores. 
Somando-se os escores em todas as competências descritas no modelo, 29\% das empresas foram classificadas no estágio Dinâmica, $27 \%$ no Integração, 20\% no Visão, $15 \%$ no Estrutura, e 9\% no estágio Fundação.

Para classificar as empresas quanto ao estágio atual de CVO, o modelo utilizado propõe mapear as características das empresas em cinco construtos: Ambiente, Modelo de decisão, Estrutura, Processamento de informação, e Distribuição de poder.

No primeiro construto, $46 \%$ dos respondentes assinalaram que trabalhavam em grandes empresas, com diretores e acionistas. Quanto ao Modelo de decisão, $41 \%$ respondeu que as decisões são tomadas por gerentes, força tarefa ou equipe de projetos. Enquanto que para a Estrutura organizacional, $25 \%$ dos participantes responderam que a estrutura organizacional poderia ser descrita como simples.

Com relação ao Processamento de informações, $31 \%$ dos respondentes apontaram que os sistemas de processamento de informações de suas empresas não são utilizados de maneira plena. Finalmente, na questão que abordava a Distribuição do poder, $40 \%$ assinalaram que, em suas empresas, o poder está concentrado nas mãos do fundador.

Dada à proporção de respostas observadas em cada construto, $36 \%$ das empresas investigadas foram classificadas no estágio Reativação, 23\% no Existência, 18\% no Sobrevivência, 12\% no Sucesso, e $12 \%$ no Declínio.

Para testar a ocorrência de relação (associação não aleatória) entre os estágios de MGL e do CVO, utilizou-se o teste do Qui-quadrado. Com a rejeição da hipótese nula desse teste concluiu-se que a associação entre os estágios de desenvolvimento dos dois modelos não é aleatória, o que confirmou a primeira hipótese de pesquisa desta dissertação (H1), de que há associação entre os estágios desses modelos teóricos.

Já para testar as hipóteses específicas $\left(\mathbf{H} 1_{\mathbf{A}}, \mathbf{H} \mathbf{1}_{\mathbf{B}}, \mathbf{H} \mathbf{1}_{\mathbf{C}}\right.$ e $\left.\mathbf{H 1} \mathbf{1}_{\mathbf{D}}\right)$, utilizou-se a análise de correspondência (ANACOR). O mapa perceptual possibilitou a verificação de cinco associações entre os estágios de MGL com os do CVO: (1) Fundação com Declínio; (2) 
Estrutura com Existência; (3) Visão com Sucesso; (4) Integração com Sobrevivência; e (5) Dinâmica com Reativação.

A hipótese $\mathbf{H} 1_{\mathbf{A}}$ não foi aceita, pois as organizações classificadas no estágio Fundação de MGL estão associadas com o estágio de Declínio do CVO. Essa informação permite concluir que as empresas devem superar rapidamente pelo estágio Fundação de MGL, sob o risco de, ao manterem-se por muito tempo nesse estágio, entrar no estágio Declínio no CVO, e que poderá levá-la à extinção (LESTER et al, 2003, p. 343).

Também não foi aceita a hipótese $\mathbf{H 1}$ B, pois o estágio Estrutura de MGL está associado ao estágio Existência do CVO. Portanto, concluiu-se que, para que uma empresa alcance o primeiro estágio do CVO, deve estar, pelo menos, no segundo estágio da MGL.

A hipótese $\mathbf{H 1}_{\mathbf{C}}$ foi parcialmente aceita, uma vez que há associação entre os estágios Visão, de MGL, e Sucesso, do CVO. Em ambos os estágios, de acordo com as teorias, a governança dos processos representam o principal objetivo, o que pode justificar a existência dessa associação.

Já a hipótese H1 $\mathbf{D}_{\mathbf{D}}$ foi aceita. Conforme a análise do mapa perceptual há associações entre os estágios Dinâmica, de MGL, e Reativação, do CVO. De acordo com as teorias desses modelos, em ambos os estágios, o foco principal é atender as necessidades dos clientes.

A associação entre o estágio Integração, de MGL, e Sobrevivência, do CVO, não era esperada. Entretanto, as teorias dos dois modelos fornecem indícios de similaridades entre esses estágios, o que permite alguma justificativa para tal associação. Nesses estágios, o foco é o aumento da competitividade e a busca por maior lucratividade (LESTER et al ,2003, p. 342; OLIVEIRA, 2009, p. 114).

A pesquisa sobre a utilização de artefatos de controle gerencial revelou um alto índice de utilização de artefatos, especialmente Análise de custo total, contrastando o estudo de FELLOUS, 2009. Portanto, recomenda-se que essa questão seja investigada com maior profundidade. De acordo com os respondentes 79,8\% das empresas utilizam Análise de custo total nas decisões logísticas, 69,0\% realizam Análise do custo para servir, 59,2\% o Supplier 
scorecard, 52,6\% o ABC, 49,8\% utilizam o Custeio alvo, 48,4\% utilizam o PNI; e apenas $28,2 \%$ dizem utilizar a GCI.

Entretanto, para o propósito de pesquisa desta dissertação, foi aceita a hipótese $\mathbf{H 2}$, sobre a existência de relação entre os estágios de desenvolvimento dos modelos de MGL e CVO e a quantidade de artefatos de controle gerencial utilizados. Quanto mais desenvolvido o estágio de MGL das empresas, maior é a quantidade média de artefatos utilizado.

A relação entre a utilização dos artefatos com os estágios do CVO existe, mas não ocorreu exatamente conforme o esperado. Nesse modelo teórico, o estágio Sucesso vem depois do Sobrevivência, no entanto, a média de utilização de artefatos do segundo foi maior. De qualquer forma, essa foi a única inversão e a diferença observada entre as médias de utilização de artefatos entre eles foi pequena.

O estágio Sobrevivência, do CVO, é crucial para as organizações, pois as empresas que conseguem atingir as margens suficientes para se manterem competitivas entram no estágio três (Sucesso), enquanto que aquelas que não conseguem atingir essa meta terão a sua continuidade comprometida (LESTER et al, 2003, p. 342). Essa pressão pelo crescimento pode justificar o fato de que há mais utilização de artefatos no estágio de Sobrevivência do que no Sucesso.

Observou-se também que as empresas classificadas no estágio Declínio, do CVO, possuem a menor média de utilização de artefatos de gestão, apenas 2,1. Este achado está coerente com a teoria do CVO, no que diz respeito a subutilização dos sistemas de informação da empresa e falta de mecanismos de controle.

Também foi verificada a quantidade média de artefatos utilizada conforme o perfil das organizações. As análises demonstraram que não há diferenças significativas na média de utilização de artefatos de controle gerencial de acordo com a idade das empresas, ou seja, o fato de uma empresa ser mais jovem não denota que ela utiliza menos artefatos de gestão.

Os resultados também evidenciaram que existe uma associação entre o porte das empresas e a quantidade média de artefatos utilizados, sendo que as empresas de grande porte possuem maior média de utilização de artefatos. No entanto, essa associação é significativa para 
distinguir apenas as empresas de grande porte, para as médias, pequenas e microempresas, não há diferença significativa na quantidade média de artefatos utilizados.

Todavia, a pesquisa apresenta algumas limitações que necessitam ser destacadas. A primeira está relacionada com a operacionalização dos construtos que determinam os estágios de MGL e CVO. É comum nas pesquisas em Ciências Sociais aplicadas que não se consiga mensurar diretamente um construto (MARTINS; THEÓPHILO, 2009, p. 93). Portanto a operacionalização desta pesquisa, viabilizada por um formulário eletrônico, demonstra que os resultados estão baseados nas percepções dos participantes da pesquisa.

Sobre os modelos teóricos, é preciso lembrar que são apenas simplificações de uma realidade, portanto, incapazes de capturar toda a complexidade o fenômeno que se estuda (MARTINS; THEÓPHILO, 2009, p. 29). Assim, deve-se reconhecer que existem variáveis que atuam sobre o fenômeno investigado, mas que não foram capturadas pelo modelo.

Também cabe ressaltar que o modelo de CVO não é o único que busca explicar o processo de desenvolvimento organizacional. Greiner (1972) propõe outro modelo em que as organizações estão em processo de constante evolução e que, de tempos em tempos, ocorrem crises de gestão, levando a empresa a um processo de revolução organizacional. Essas revoluções marcariam as passagens para uma nova fase de desenvolvimento organizacional. Entretanto, o modelo de Greiner (1972) não considera o estágio de declínio e também os construtos não estão operacionalizados em forma de questionário.

Já para a classificação do estágio atual de MGL, o modelo utilizado considera a presença de determinadas competências na prática da gestão logística, não foi contemplado, contudo, a verificação de diferenças quanto ao nível de complexidade das cadeias de suprimentos. A consultoria PMG, Performance Measurement Group, analisou 121 cadeias e concluiu que existe correlação entre o nível de maturidade da gestão logística e a complexidade da cadeia, sendo que cadeias com práticas mais maduras, de acordo com o modelo de maturidade desenvolvido pela PMG, conseguem reduzir a complexidade e atingir melhor desempenho operacional (PMG, 2007, p. 34).

Como recomendações para pesquisas futuras, há oportunidade de investigação da relação entre estágios de maturidade da gestão logística e o nível de complexidade da cadeia, bem 
como o segmento onde a empresa atua. Não foi encontrado estudo semelhante na literatura brasileira sobre esse tema.

Outra limitação desta pesquisa refere-se ao método de tratamento dos dados (ANACOR). Essa é uma técnica exploratória, para analisar a associação entre variáveis em um espaço multidimensional, contudo, não tem poder explicativo sobre qual das variáveis exerce influencia sobre a outra (FÁVERO et al,2009, p. 301). Para resolver esse problema de relações de dependências inter-relacionadas e simultânea, HAIR et al, (2005, p. 466) recomenda a utilização técnicas confirmatórias, como a modelagem de equações estruturais.

Portanto, como outra recomendação para pesquisas futuras, sugere-se o aprofundamento na investigação das relações entre os estágios dos modelos teóricos, no sentindo de analisar a dinâmica do relacionamento, ou seja, qual modelo exerce maior influência. Essa investigação pode ser importante para decisões dos gestores de priorização de projetos de maturidade.

Considerando que os constructos do modelo de MGL Integração com clientes (C-09). Integração com fornecedores (C-10) e Comportamento estratégico (C-11) foram os que obtiveram menor percentual de atribuições por parte dos respondentes, existe oportunidade para o desenvolvimento de pesquisas que possam investigar e explicar os principais motivos dessa deficiência na gestão logística. Pesquisas nesse sentindo podem são valiosas para outros áreas de estudo, como a Gestão Estratégica.

Recomenda-se também que o estudo sobre a utilização de artefatos de gestão pelas empresas seja investigado com maior profundidade. Sugere-se que, em pesquisas futuras, as questões acerca da utilização de tais artefatos sejam elaboradas de forma a buscar indícios de sua utilização, e não de maneira direta, como foi realizado nesta dissertação. Assim, ao invés de perguntar se as empresas utilizam Análise de Custo Logístico Total, o pesquisador deve buscar indícios de utilização de desse artefato, por exemplo, se há uma cotação dos custos de distribuição por diferentes canais, se há comparação entre eles, se são considerados todos os impactos e se a decisão ocorre por critério de menor custo total.

Finalmente, para investigar os motivos do baixo índice de utilização do artefato GCI, recomenda-se que as pesquisas nessa área sejam aprofundadas no sentido de buscar explicações para a baixa utilização desse artefato pelas organizações, uma vez que a GCI é 
uma maneira para tornar a cadeia de suprimentos mais eficiente e aumentar a sua lucratividade total (COOPER; SLAGMULDER, 2003a, p. 14). 


\section{REFERÊNCIAS}

APICS - The Association for Operations Managements - Disponível em: www.apics.org (último acesso em 06/10/2010).

ANTHONY, Robert N.; GOVINDARAJAN, Vijay. Sistema de Controle Gerencial. 12. ed. São Paulo: McGraw-Hill, 2008.

ANSARI, Shahid et al. Target costing: uncharted research territory. In: Chapman, C. S. et al (Org.). Handbook of management accounting. Oxford, vol. 2, 2007.

ARYEE, Gilbert; NAIM, Mohamed M.; LALWANI, Chandra. Supply chain integration using a maturity scale. Journal of Manufacturing Technology Management. Birmingham, vol. 19, n. 5. 2008.

ASSAF NETO, Alexandre; LIMA, Fabiano G.; ARAÚJO, Adriana Maria P. Uma proposta metodológica para o cálculo do custo de capital próprio no Brasil. Revista de Administração. São Paulo, vol. 43, n. 1, Jan-Mar 2008.

BERTALANFFY, Ludwig V. Teoria geral dos sistemas. Petrópolis: Vozes, 1977.

BIO, João Roberto R. Visão econômica e financeira de impactos da logística nos resultados. MBA Supply Chain Management e logística integrada: Fipecafi, 2011.

BLOCHER, Edward J.; STOUT, David E.; COKINS, Gary. Cost Management. A strategic emphasis. 5. Ed. New York: McGraw-Hill, 2010.

BRAITHWAITE, Alan; SAMAKH, Edouard. The cost-to-serve method. International Journal of Logistics Management, Pensacola, v. 9, n. 1, 1998.

BOWERSOX, Donald J.; CLOSS, David J.; COOPER, M. Bixby. Supply chain logistics management. 3. ed. New York: McGraw-Hill, 2010.

CAPAR, Ismail; ULENGIN, Fusun; REISMAN, Arnold. Taxonomy for Supply Chain Management Literature. Mississippi State University: (working paper), 2004.

CASTRO, Cláudio Moura. A prática da pesquisa. São Paulo: McGraw-Hill do Brasil, 1978.

CHEN, Haozhe; DAUGHTERTY, Patricia J.; ROATH Anthony S. Defining and operationalizing supply chain process integration. Journal of Business Logistics. Oklahoma, vol. 30, n. 1, 2009. 
CHEN, Haozhe; DAUGHERTY, Patricia J.; LANDRY, Timothy D. Supply chain process integration: a theoretical framework. Journal of Business Logistics. Oklahoma, v. 30, n. 2, 2009.

COMELLIA, Mickael; FENIES, Pierre; TCHERNEVA, Nikolay. A combined financial and physical flows evaluation for logistic process and tactical production planning: application in a company supply chain. International Journal of Production Economics, Linköping, $\mathrm{n}$. $112,2008$.

COOPER, Robin; SLAGMULDER, Regine. Strategic cost management: expanding scope and boundaries. Cost Management, ABI/INFORM Global, v. 17, n. 1, Jan./Feb. $2003 \mathrm{a}$.

Interorganizational costing. Part I. Cost Management, v. 17, n. 5, Sept./Oct. 2003b.

Interorganizational costing. Part II. Cost Management, v. 17, n. 5, Nov./Dec. 2003c

CORREIA, Roriodo B; GOMES, Sonia M. S.; FILHO, JOSÉ B. C.; ALBUQUERQUE, Kátia S. L. S. Análise dos modelos de ciclo de vida organizacional aplicados em pesquisas empíricas. In XVII Congresso Brasileiro de Custos. Belo Horizonte: anais, 2010

DOANE, David P.; SEWARD, Lori E. Estatística aplicada à Administração e à Economia. São Paulo: McGraw-Hill, 2008.

FACCI, Nilton. Logística: um desafio constante para a Controladoria. Revista CESUMAECiências Humanas e Sociais Aplicadas, vol. 6, n. 1 / 2002.

FARIA, Ana C. de; COSTA, Maria de F. G. da. Gestão de custos logísticos. São Paulo: Editora Atlas, 2008.

FÁVERO, Luiz Paulo; BELFIORE, Patrícia; SILVA, Fabiana Lopes da; CHAN, Betty Lilian. Análise de dados: modelagem multivariada para tomada de decisões. Rio de Janeiro: Campus, 2009.

FAWCETT, Stanley E.; MAGNAN, Gregory M.; McCARTER, Matthew W. A three-stage implementation model for supply chain collaboration. Journal of Business Logistics, Oklahoma, n 29, n. 1, 2008.

FREDERICO, Guilherme; MARTINS, Roberto Antônio. Modelos de maturidade para a gestão da cadeia de suprimentos. Revista Mundo Logística, Curitiba, n. 5, 2010.

FREZATTI, Fábio; et al. Análise do perfil de planejamento associado ao ciclo de vida organizacional nas empresas brasileiras. Congresso USP de Controladoria e Contabilidade: Anais, 2009. 
GREINER, Larry E. Evolution and revolution as organization Grow: A company's past has clue for management that are critical to future success. Harvard Business Review, 1997.

GUERREIRO, Reinaldo; BIO, Sergio Rodrigues; MERSCHMANN, Elvira Vazquez Villamor. Cost-to-serve measurement and customer profitability analysis. The International Journal of Logistics Management. Pensacola, vol. 19, n. 3, 2008.

HENRI, Jean-François. Management control systems and strategy: a resource-based perspective. Accounting, Organizations and Society, London, vol. 31, 2006.

IMA - Institute of Management Accountants. Implementing integrated supply chain management for competitive advantage. Statement on Management Accounting, Buffalo, vol. 67, 1999.

JUNQUEIRA, Emanuel R. Perfil do sistema de controle gerencial sob a perspectiva da teoria da contingência. Tese apresentada ao Departamento de Contabilidade e Atuaria da Faculdade de Economia, Administração e Contabilidade: São Paulo, 2010.

LAMBERT, Douglas M.; BURDUROGLU, Renan. Measuring and selling the value of logistics, The International Journal of Logistics Management, Pensacola, v. 30, n. 1, 2000.

LAMBERT, Douglas M.; STOCK, James R. Strategic Logistic Management. 3. ed. New York: McGraw-Hill, 1993.

LESTER, D.; PARNELL, J.A.; CAHARRER, S. Organizational life cycle: a five stage empirical scale. The International Journal of Organizational Analysis, [S.1.], v. 11, n. 4, 2003.

LOCKAMY, A., MCCORMACK, K. The development of a supply chain management process maturity model using the concepts of business process orientation. Supply Chain Management; 9, 3/4, 2004.

MAROCO, J. Análise estatística com utilização do SPSS. Lisboa: Edições Sílabo, 2007.

MARQUES, Kelly C. M.; SOUZA, Rodrigo P. Pontos críticos da abordagem da contingência nos estudos de contabilidade gerencial. In XVII Congresso Brasileiro de Custos, Belo Horizonte: anais, 2010.

MARTINS, G. Estatística geral e aplicada. São Paulo: Editora Atlas, 2005.

MARTINS, G. A; THEÓPHILO, C. R. Metodologia da investigação científica para Ciências Sociais Aplicadas. São Paulo: Editora Atlas, 2009.

MCCOMARK, Kevin; LADEIRA, Marcelo Bonzo; OLIVEIRA, Marcos Paulo Valadares de. Supply chain maturity and performance in Brazil. Supply Chain Management; 13/4, 2008. 
MCCORMACK, Kevin et al. A global investigation of key turning points in business process maturity. Business Process Management Journal. Ryiadh, vol..15, n. 5, 2009.

MILLER, Danny; FRIESEN, Peter H. A longitudinal study of the corporate life cycle. Management Science (pre-1986), 1984.

OLIVEIRA, Marcos Paulo Valadares de. Modelo de maturidade em processos de cadeia de suprimentos: precedências e ponto chave de transição. Tese (Doutorado em Administração) Centro de Pós-graduação em Administração da Universidade Federal de Minas Gerais: Belo Horizonte, 2009.

MUZUMDAR, Maha; VISWANATHAN, Nari. Integrated business planning: kicking S\&OP up a notch. Supply Chain Management Review. New York, vol. 13, n. 7, 2009.

PMT - The Performance Measurement Group. Supply chain performance: competitive advantages of best-in-class supply chains. Presented at Supply Chain World, North American Conference, Philadelphia, Pennsylvania, 2007. Disponível em <htpp://www.pmgbenchimarking.com>. Acessado em Maio/2011.

QUINN, Robert E.; CAMERON, Kim. Organizational life cycle and shifting criteria of effectiveness: some preliminary evidence. Management Science (pre-1986), 1983.

RODRIGUES, Carlos M. Taboada et al. O modelo de referência das operações na cadeia de suprimentos - (SCOR Model). XXVI ENEGEP - Anais, Fortaleza, 2006.

SAMPIERI, Roberto H.; COLLADO, Carlos F.; Lucio, Pilar B. Metodologia de pesquisa. McGraw-Hill: São Paulo, 2006.

SEBRAE - Serviço de Apoio às Micro e Pequenas Empresas. Disponível em $<$ http://www.sebrae-sc.com.br/leis/default.asp?vcdtexto=4154>. Acessado em: Jun/2011.

SWEET, Kathleen M.; LEE, Yoo T. Development analysis of supply chain strategy taxonomy. Journal of Supply Chain Management, Nevada. vol. 45, n. 3, 2009.

TRENT, Robert J. Creating the ideal supplier scorecard. Supply Chain Management Review. New York: Mar, vol. 14, n. 2, 2010.

TrKMAN, Peter; TEMBERGER, Mojca Indihar S `; JAKLIC`, Jurij; GROZNIK, Ales`. Process approach to supply chain integration. Supply Chain Management. Glasgow, vol. 12, n.2, 2007.

WANG, Geng; GAO, Zhongming; LIN, Thomas W. Using ABC to improve the logistics value chain in chinese food product company. Cost Management, 2010 .

WEBSTER, Allen L. Estatística aplicada à Administração e à Economia. São Paulo: McGraw-Hill, 2007. 


\section{APÊNDICES}

APÊNDICE 1 - Termo de confidencialidade do questionário APÊNDICE 2 - Identificação do perfil dos respondentes e da empresa APÊNDICE 3 - Modelo para construção do questionário de MGL APÊNDICE 4 - Questionário de Maturidade da Gestão Logística APÊNDICE 5 - Análise das traduções do questionário sobre CVO APÊNDICE 6 - Questionário traduzido referente ao CVO APÊNDICE 7 - Questões sobre a utilização de artefatos de controle gerencial 
Apêndice 1 - Termo de confidencialidade do questionário

Informação ao respondente:

\section{TERMO DE COMPROMISSO}

Esta pesquisa faz parte de um projeto de dissertação de mestrado da FEA-USP e tem como objetivo mapear as empresas em termos de estágio de maturidade da gestão da cadeia de suprimentos e estágio de desenvolvimento do ciclo de vida organizacional.

O pesquisador se compromete a tratar as respostas recebidas dentro dos critérios éticos, responsáveis e com a confidencialidade que requer a pesquisa acadêmica.

Cada respondente receberá, ao final da pesquisa, um relatório individual contendo o estágio de desenvolvimento em que a sua empresa foi classificada de acordo com os modelos teóricos e a classificação média das empresas pesquisadas, permitindo assim a comparação da sua empresa em relação a população amostral dessa pesquisa.

Atenciosamente,

Rodrigo Paiva Souza

Pesquisador FEA-USP

rodrigo.paiva.souza@usp.br
Reinaldo Guerreiro

Orientador da pesquisa

Diretor da FEA-USP 
Apêndice 2 - Identificação do perfil do respondente e da empresa

Qual o seu e-mail?

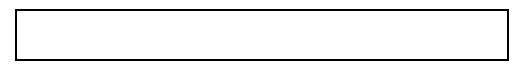

Qual o nome da empresa?

Qual o ano de fundação?

Quantos empregados trabalham na empresa?

\begin{tabular}{|l|}
\hline Menos de 20 \\
\hline Entre 20 e 99 \\
\hline Entre 100 e 499 \\
\hline Mais de 500 \\
\hline
\end{tabular}

Qual a sua área de atuação na empresa?

\begin{tabular}{|l|}
\hline Compras / suprimentos \\
\hline Operações / produção \\
\hline Distribuição \\
\hline Marketing / vendas \\
\hline Serviço ao cliente \\
\hline Gestão logística interna \\
\hline Gestão logística externa \\
\hline Administração \\
\hline Financeira \\
\hline Controladoria \\
\hline Outra \\
\hline
\end{tabular}

Qual posição melhor define a sua função na organização?

\begin{tabular}{|l|}
\hline Presidente \\
\hline Diretor \\
\hline Gerente \\
\hline Coordenador \\
\hline Supervisor \\
\hline Consultor \\
\hline Analista \\
\hline Outro \\
\hline
\end{tabular}


Apêndice 3 - Modelo para construção do questionário MGL

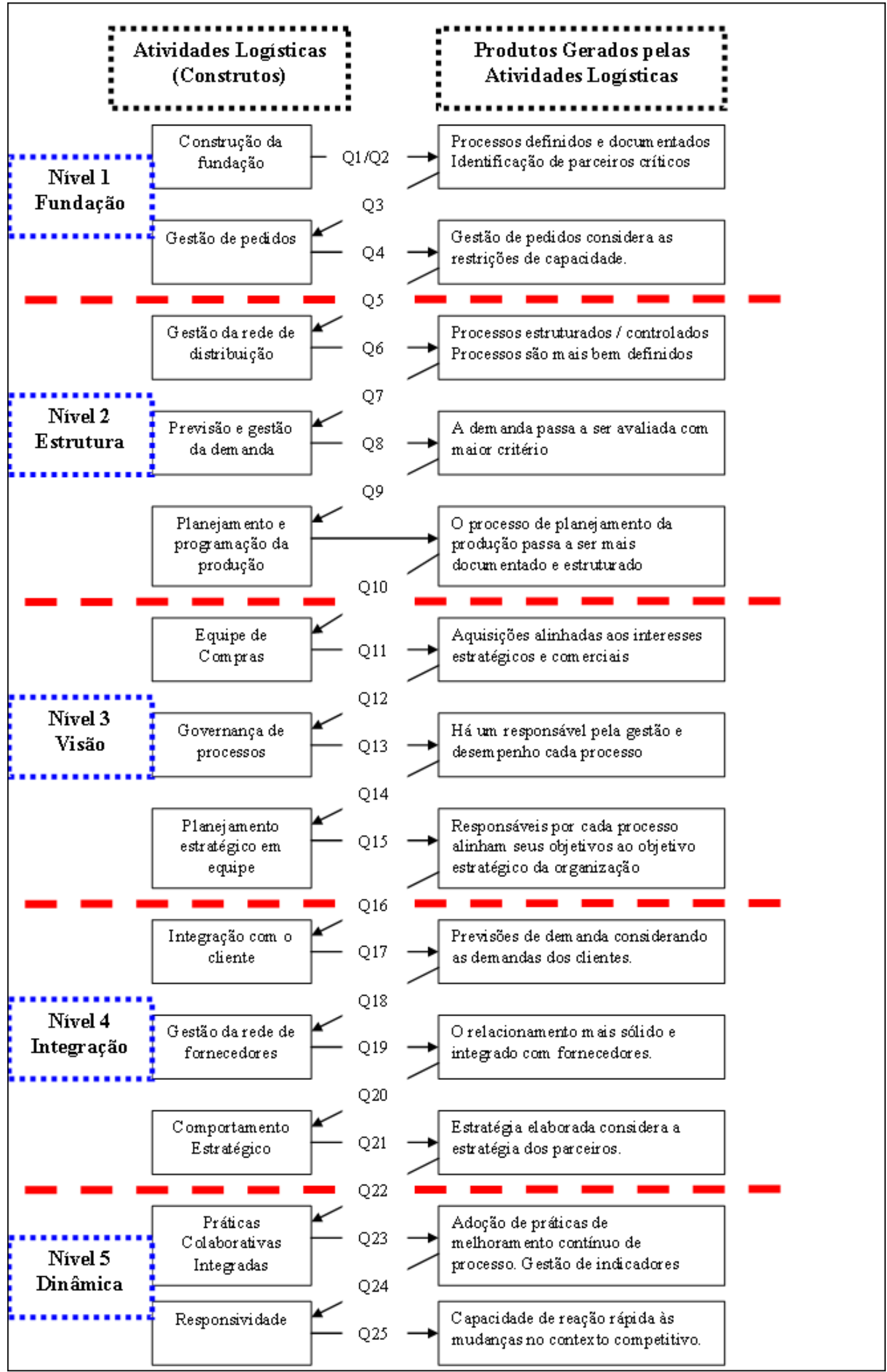




\section{APÊNDICE 4 - Questionário de Maturidade da Gestão Logística (MGL)}

Para cada questão assinalar na escala de (1) a (5), de acordo com a situação na sua empresa, sendo que (1) significa discordo totalmente e (5) concordo totalmente.

Q1 - Os principais processos (planejamento, suprimentos, produção e distribuição) estão mapeados e documentados.

Q2 - Os parceiros chave (principais fornecedores e clientes para a operação) estão identificados.

Q3 - A gestão e controle de pedidos entre a empresa e seus principais clientes são documentados.

Q4 - A gestão de pedidos com clientes considera a capacidade máxima de oferecimento de produtos/serviços da sua empresa.

Q5 - A restrição de capacidade da empresa é condição para aceitar qualquer novo pedido.

Q6 - O processo de distribuição de produtos/serviços é estruturado e controlado.

Q7 - Os contratos com clientes são utilizados como ferramenta de previsão da demanda.

Q8 - A previsão da demanda considera as restrições da empresa e do cliente.

Q9 - As informações sobre a previsão da demanda alimentam o processo de planejamento da produção.

Q10 - A equipe de suprimentos (e compras) recebe informações sobre o planejamento da produção.

Q11 - A atividade de suprimentos utiliza sistema de informações integrado às áreas de planejamento de produção e planejamento da distribuição.

Q12 - As áreas chave do processo logístico (planejamento, suprimento, produção e distribuição) têm acesso a informações atualizadas sobre os estoques de matéria prima e de produtos acabados.

Q13 - Existem gestores responsáveis por cada área chave do processo logístico.

Q14 - Os responsáveis pelas áreas chaves do processo logístico se reúnem periodicamente.

Q15 - Os objetivos individuais de cada área chave estão alinhados ao objetivo global da empresa.

Q16 - O sistema de informações da empresa está integrado diretamente com o sistema de informações dos clientes.

Q17 - A previsão da demanda da empresa considera a demanda do cliente como uma das restrições.

Q18 - As informações sobre a demanda dos clientes são atualizadas no sistema da empresa e utilizadas para realizar a gestão da rede de fornecedores.

Q19 - O relacionamento com os fornecedores e clientes é sólido e pautado na confiança e colaboração.

Q20 - O planejamento estratégico global é discutido com os parceiros chave da cadeia logística.

Q21 - A estratégia para a cadeia logística é comunicada e integrada entre os parceiros chave.

Q22 - Mudanças em qualquer etapa do processo logístico são comunicadas e ajustadas entre parceiros chave.

Q23 - A cadeia adota práticas de melhoramento contínuo dos processos e são gerados indicadores de desempenho.

Q24 - Os indicadores de desempenho dos principais processos são monitorados periodicamente por meio de sistema integrado.

Q25 - A empresa e seus parceiros, por estarem integrados, têm capacidade de reagir rapidamente para as novas contingências tanto internas quanto externas. 
Apêndice 5 - Análise das traduções do questionário sobre CVO

Pesquisadores tradutores:

Renata Turola Takamatsu
Rodrigo Paiva Souza
Tânia Cristina Silva Nunes
Valdomiro Benjamim Junior

\section{Q01-CVO}

Our organization is small, both in size and relative to our competitors.

Renata: Nossa empresa é pequena, tanto em tamanho como quando comparada com nossos competidores.

Rodrigo: Nossa organização é pequena, tanto em tamanho como em relação aos nossos concorrentes.

Tânia: Nossa organização é pequena, tanto em tamanho quanto em relação aos nossos concorrentes.

Valdomiro: Nossa empresa é pequena, tanto em tamanho quanto em comparação com nossos concorrentes.

Q01- CVO: Nossa empresa é pequena, tanto em tamanho quanto em comparação com nossos concorrentes

\section{Q02-CVO}

As a firm, we are larger than most of our competitors, but not as large as we could be.

Renata: Como empresa, somos maiores que nossos competidores, mas não somos tão grandes quanto poderíamos ser.

Rodrigo: Como uma empresa, nós somos maiores do que a maioria de nossos concorrentes, mas não tão grande como poderia ser.

Tânia: Como empresa, somos maiores do que a maioria dos nossos concorrentes, mas não tão grandes quanto poderíamos ser

Valdomiro: Como empresa, nós somos maiores que a maioria de nossos concorrentes, porém não tão grande quanto poderíamos ser.

Q02- CVO: Como uma empresa, nós somos maiores do que a maioria de nossos concorrentes, mas não tão grande como poderia ser.

\section{Q03-CVO}

We are a widely dispersed organization, with a board of directors and shareholders.

Renata: Somos uma empresa de propriedade bastante dispersa, com um conselho de diretores e com acionistas.

Rodrigo: Somos uma organização muito dispersa, com um conselho de diretores e acionistas.

Tânia: Somos uma organização amplamente dispersa, com um conselho de administração e acionistas

Valdomiro: Somos uma grande empresa, com um conselho de diretores e acionistas.

Q03- CVO: Somos uma grande empresa, com um conselho de diretores e acionistas.

\section{Q04-CVO}

The seat of power in our firm is primarily in the hands of the founder.

Renata: O poder em nossa firma está principalmente nas mãos do fundador.

Rodrigo: A sede do poder em nossa sociedade está principalmente nas mãos de seu fundador.

Tânia: A base do poder em nossa empresa está, essencialmente, nas mãos do fundador

Valdomiro: A presidência de nossa empresa está nas mãos do fundador.

Q04- CVO: O poder em nossa empresa está concentrado principalmente nas mãos do fundador.

\section{Q05-CVO}

Power in our firm is spread among a group of several owner/investors.

Renata: O poder em nossa companhia está disperso em um grupo composto por uma série de proprietários/investidores.

Rodrigo: O poder em nossa empresa é distribuída entre um grupo de proprietários diversos / investidores.

Tânia: O poder, em nossa empresa, está distribuído entre um grupo de diversos proprietários/investidores

Valdomiro: O poder na nossa empresa está dividido entre um grupo de vários proprietários/investidores.

Q05-CVO: O poder na nossa empresa está dividido entre um grupo composto por vários proprietários / investidores.

\section{Q06-CVO}

Power in our firm is concentrated in our vast number of shareholders

Renata: O poder em nossa firma está concentrado em um grande número de acionistas.

Rodrigo: O poder de decisão em nossa empresa está distribuído entre um vasto número de acionistas.

Tânia: O poder, em nossa empresa, está concentrado em uma grande quantidade de acionistas

Valdomiro: O poder na nossa empresa está concentrado no vasto número de acionistas.

Q06- CVO: O poder de decisão em nossa empresa está distribuído entre um grande número de acionistas. 


\section{Q07-CVO}

Our firm's organizational structure could best be described as simple.

Renata: A estrutura organizacional de nossa firma pode ser descrita como simples.

Rodrigo: Estrutura organizacional da nossa empresa poderia ser descrita como simples.

Tânia: A estrutura organizacional da nossa empresa pode ser mais bem descrita como "simples"

Valdomiro: A estrutura organizacional de nossa empresa pode ser mais bem definida como sendo uma estrutura simples.

Q07- CVO: Estrutura organizacional da nossa empresa poderia ser descrita como simples.

\section{Q08-CVO}

Our structure is department-based and functional, becoming much more fonnal

Renata: Nossa estrutura baseada em departamento e em funções se tornou muito formal.

Rodrigo: Nossa estrutura é baseada em departamento funcionais, tornando-se muito mais formal.

Tânia: Nossa estrutura é funcional e baseada em departamentos, tornando-se muito mais formal (?)

Valdomiro: Nossa estrutura é departamental e funcional, se tornando muito mais formal (?).

Q08- CVO: Nossa estrutura é departamental e funcional e se tornou muito formal

\section{Q09-CVO}

Structure in our firm is divisional or matrix in nature, with highly sophisticated control systems.

Renata: A estrutura de nossa firma, baseada na natureza inerente das funções de cada divisão, possui sistemas de controle altamente sofisticados.

Rodrigo: Estrutura em nossa empresa é de divisão ou de matriz, com sistemas de controle sofisticados.

Tânia: Em nossa empresa, a estrutura é organizada em divisões ou em matriz, com sistemas de controle altamente sofisticados

Valdomiro: A estrutura na nossa empresa é divisional ou matricial, com sistemas de controles altamente sofisticado.

Q09- CVO: A estrutura de trabalho em nossa empresa é divisional ou matricial, com sistemas de controles altamente sofisticado.

Our structure is centralized with few control systems.

\section{Q10-CVO}

Renata: Nossa estrutura é centralizada, com apenas alguns sistemas de controle.

Rodrigo: Nossa estrutura é centralizada, com alguns sistemas de controle.

Tânia: Nossa estrutura é centralizada, com poucos sistemas de controle

Valdomiro: Nossa estrutura é centralizada com poucos sistemas de controles

Q10- CVO: Nossa estrutura é centralizada, com apenas alguns sistemas de controle.

\section{Q11-CVO}

In our organization, we have some specialization (accountants and possibly engineers, e.g.) and we are becoming somewhat differentiated.

Renata: O quadro funcional de nossa organização apresenta profissionais especializados (contadores ou engenheiros, por exemplo) o que está nos tornando, de alguma maneira, uma empresa diferenciada.

Rodrigo: Na nossa organização, temos alguma especialização (contabilistas e, possivelmente, engenheiros, por exemplo) e estamos nos tornando um pouco diferenciados.

Tânia: Em nossa organização, há certo nível de especialização (contadores e, possivelmente, engenheiros, por exemplo) e estamos nos tornando ligeiramente diferenciados

Valdomiro: Na nossa organização, nós temos alguma especialização (contadores e possivelmente engenheiros, por exemplo) e estamos de alguma forma nos tornando diferenciados.

Q11- CVO: Na nossa organização, há certo nível de especialização (contadores e possivelmente engenheiros, por exemplo) e estamos de alguma forma nos tornando diferenciados.

\section{Q12-CVO}

Information processing could best be described as simple, mostly word-of-mouth.

Renata: O processo de informação é mais bem descrito como simples.

Rodrigo: O processamento de informações poderia ser descrito como simples, baseado no boca a boca.

Tânia: O processamento de informações pode ser mais bem descrito como "simples", em geral, ocorrendo bocaa-boca

Valdomiro: O processamento de informação pode ser melhor descrito como sendo simples, muitas vezes informal.

Q12- CVO: O processamento de informação pode ser melhor descrito como sendo simples, muitas vezes informal. 
Q13-CVO

Information processing is best described as monitoring performance and facilitating communication between departments.

Renata: O processo de informação é mais bem descrito como um processo que monitora a performance a facilita a comunicação entre departamentos.

Rodrigo: O processamento de informações monitoradora o desempenho e facilita a comunicação entre os departamentos.

Tânia: O processamento de informações é mais bem descrito como monitorar o desempenho e facilitar a comunicação entre os departamentos

Valdomiro: O processamento de informação é melhor descrito como sendo um monitor de desempenho e um facilitador da comunicação entre os departamentos.

Q13- CVO: O processamento de informações monitoradora o desempenho e facilita a comunicação entre os departamentos.

\section{Q14-CVO}

Information processing is sophisticated and necessary for efficient production and earning adequate profits.

Renata: O processo de informação é sofisticado e necessário para uma produção eficiente e geração adequada de lucros.

Rodrigo: O processamento de informações é sofisticado e necessário para gerar uma produção eficiente e lucros adequados.

Tânia: O processamento de informações é sofisticado e necessário para a eficiência da produção e gerar lucro suficiente

Valdomiro: O sistema de informação é sofisticado e necessário para uma produção eficiente e adequada lucratividade.

Q14- CVO: O processamento de informações é sofisticado e necessário para gerar uma produção eficiente e lucratividade adequados.

\section{Q15-CVO}

Information processing is very complex, used for coordination of diverse activities to better serve markets.

Renata: O processo de informação é bastante complexo, utilizado para coordenar diversas atividades e para melhor servir o Mercado.

Rodrigo: O processamento de informações é muito complexo, utilizado para coordenação de diversas atividades para melhor atender os mercados.

Tânia: O processamento de informações é muito complexo, usado para coordenação de diversas atividades para melhor servir os mercados

Valdomiro: O processamento de informação é muito complexo, usado para a coordenação de diversas atividades para melhor servir o Mercado.

Q15- CVO: O processamento de informação é bastante complexo, utilizado para coordenar diversas atividades e para melhor servir o Mercado.

\section{Q16-CVO}

Information processing is not very sophisticated, but badly needed.

Renata: O processamento de informações não é muito sofisticado, mas altamente necessário.

Rodrigo: O processamento de informações não é muito sofisticado, mas também não é muito necessário.

Tânia: $\mathrm{O}$ processamento de informações não é muito sofisticado, mas um mal necessário (?)

Valdomiro: O processamento de informação não é muito sofisticado, mas é raramente necessário.

Q16- CVO: O processamento de informações não é muito sofisticado, mas altamente necessário.

\section{Q17-CVO}

Decision-making is centralized at the top of the organization and considered to be not very complex.

Renata: O processo decisório é centralizado no topo da organização e não é considerado muito complexo.

Rodrigo: A tomada de decisão é centralizado no topo da organização e considerada não ser muito complexa.

Tânia: A tomada de decisão é centralizada no topo da organização e não é considerada muito complexa

Valdomiro: O processo decisório é centralizado no topo da organização e considerado como não sendo muito complexo.

Q17- CVO: O processo decisório é centralizado no topo da organização e não é considerado muito complexo. 


\section{Q18-CVO}

Most decisions in our firm are made by a group of managers who utilize some systematic analyses, but who are still fairly bold.

Renata: A maioria das decisões é tomada por um grupo de gestores que empregam algumas análises sistemáticas, mas que não são suficientemente ousadas.

Rodrigo: A maioria das decisões de nossa empresa são tomadas por um grupo de gestores que utilizam algumas análises sistemáticas, mas que ainda são bastante ousadas.

Tânia: Em nossa empresa, a maioria das decisões é tomada por um grupo de gestores que utilizam algumas análises sistemáticas, mas que ainda são bastante arrojados.

Valdomiro: Muitas das decisões da nossa empresa são tomadas por um grupo de gerentes que utilizam alguma análise sistemática, mas mesmo assim bastante ousada.

Q18- CVO: A maioria das decisões da nossa empresa é tomada por um grupo de gestores que empregam algumas análises sistemáticas, mas que não são suficientemente ousadas.

\section{Q19-CVO}

Most decisions in our firm are made by managers, task forces, and project teams who are trying to facilitate growth through participation.

Renata: A maioria das decisões é tomada por gestores e equipes que buscam proporcionar o crescimento por meio da participação.

Rodrigo: A maioria das decisões da nossa empresa são feitas por gerentes, forças-tarefas, equipes de projetos que tentam promover o crescimento através da participação.

Tânia: Em nossa empresa, a maioria das decisões é tomada por gestores, forças-tarefa (?), e equipes de projeto que tentam promover o crescimento por meio da participação

Valdomiro: Muitas das decisões na nossa empresa são tomadas por gerentes, força tarefa, e equipes de projetos, nos quais tentam facilitar o crescimento através da participação.l

Q19- CVO: A maioria das decisões da nossa empresa é tomada por gerentes, força tarefa, e equipes de projetos que tentam promover o crescimento através da participação.

\section{Q20-CVO}

Most decisions in our firm are made by a few managers who take a conservative, internally political approach Renata: A maioria das decisões é tomada por alguns gerentes que utilizam uma abordagem conservadora e de acordo com a política interna.

Rodrigo: A maioria das decisões de nossa empresa são tomadas por poucos gerentes, que adotam uma postura conservadora, baseadas nas políticas internas.

Tânia: Em nossa empresa, a maioria das decisões é tomada por alguns gestores que assumem uma abordagem conservadora e política internamente (?)

Valdomiro: Muitas das decisões na nossa empresa são tomadas por alguns gerentes que possuem uma abordagem interna política e conservadora.

Q20- CVO: A maioria das decisões de nossa empresa é tomada por poucos gerentes, que adotam uma postura conservadora, baseada nas políticas internas. 
APÊNDICE 6 - Questionário traduzido referente ao CVO

Adaptado de Lester et al (2003)

Qual das afirmações abaixo melhor descreve o AMBIENTE em que a sua empresa está inserida? (assinale apenas uma alternativa)

Nossa empresa é pequena, tanto em tamanho quanto em comparação com nossos concorrentes.

Como uma empresa, nós somos maiores do que a maioria de nossos concorrentes, mas não tão grande como poderia ser.

Somos uma grande empresa, com diretores e acionistas.

Qual situação melhor descreve o MODELO DE DECISÃO na sua empresa? (assinale apenas uma alternativa)

O processo decisório é centralizado no topo da organização e não é considerado muito complexo. A maioria das decisões da nossa empresa é tomada por um grupo de gestores que empregam algumas análises sistemáticas, mas que não são suficientemente ousadas.

A maioria das decisões da nossa empresa é tomada por gerentes, força tarefa, e equipes de projetos que tentam promover o crescimento através da participação.

Qual situação melhor descreve a ESTRUTURA ORGANIZACIONAL na sua empresa? (assinale apenas uma alternativa)

Estrutura organizacional da nossa empresa poderia ser descrita como simples.

Nossa estrutura é departamental e funcional e se tornou muito formal.

A estrutura de trabalho em nossa empresa é divisional ou matricial, com sistemas de controles altamente sofisticados.

Nossa estrutura é centralizada, com apenas alguns sistemas de controle.

Na nossa organização, há certo nível de especialização (contadores e possivelmente engenheiros, por exemplo) e estamos de alguma forma nos tornando diferenciados.

Qual situação melhor descreve o PROCESSAMENTO DE INFORMAÇÕEES na sua empresa? (assinale apenas uma alternativa)

O processamento de informação pode ser melhor descrito como sendo simples, muitas vezes informal.

O processamento de informações monitora o desempenho e facilita a comunicação entre os departamentos.

O processamento de informações é sofisticado e necessário para gerar uma produção eficiente e lucratividade adequada.

O processamento de informação é bastante complexo, utilizado para coordenar diversas atividades e para melhor servir o Mercado.

O processamento de informações não é muito sofisticado, mas altamente necessário.

O processamento de informações não é utilizado da maneira plena

Qual situação melhor descreve a distribuição do PODER na sua empresa? (assinale apenas uma alternativa)

O poder em nossa empresa está concentrado principalmente nas mãos do fundador.

O poder na nossa empresa está dividido entre um grupo composto por vários proprietários / investidores.

O poder de decisão em nossa empresa está distribuído entre um grande número de acionistas. 
APÊNDICE 7 - Questões sobre utilização de artefatos de Controle Gerencial

\begin{tabular}{|l|l|l|}
\hline \multicolumn{1}{|c|}{ Questões relacionadas à utilização de artefatos de controle gerencial } & Sim & Não \\
\hline $\begin{array}{l}\text { A sua empresa utiliza ferramentas gerenciais para mensuração de desempenho } \\
\text { dos fornecedores? }\end{array}$ & & \\
\hline $\begin{array}{l}\text { A sua empresa utiliza método de custeio por atividade (ABC) para mensurar os } \\
\text { custos logísticos? }\end{array}$ & & \\
\hline $\begin{array}{l}\text { A sua empresa adota um plano de negócio integrado com parceiros da cadeia de } \\
\text { suprimentos? }\end{array}$ & & \\
\hline $\begin{array}{l}\text { A sua empresa possui algum programa de gestão de custos interorganizacional } \\
\text { com parceiros da cadeia de suprimentos? }\end{array}$ & & \\
\hline A sua empresa adota prática de custeio alvo com fornecedores e/ou clientes? & & \\
\hline $\begin{array}{l}\text { A sua empresa mensura o custo para servir os diversos canais de distribuição } \\
\text { e/ou famílias de produtos? }\end{array}$ & $\begin{array}{l}\text { A sua empresa emprega a análise de custo total para tomar decisões estratégicas } \\
\text { na cadeia de suprimentos? }\end{array}$ & \\
\hline
\end{tabular}


114

ANEXOS

ANEXO A - Questionário original Lester et al (2003)

ANEXO B - Questionário original Oliveira (2009) 


\section{ANEXO A - Questionário original de Lester et al (2003)}

Respondents were asked to rate the following statements based on the scale of 1 to 5. (1) Strongly disagree, (2) disagree, (3) neutral, (4) agree, and (5) strongly agree.

1. Our organization is small, both in size and relative to our competitors.

2. As a firm, we are larger than most of our competitors, but not as large as we could be.

3. We are a widely dispersed organization, with a board of directors and shareholders.

4. The seat of power in our firm is primarily in the hands of the founder.

5. Power in our firm is spread among a group of several owner/investors.

6. Power in our firm is concentrated in our vast number of shareholders.

7. Our firm's organizational structure could best be described as simple.

8. Our structure is department-based and functional, becoming much more fonnal.

9. Structure in our firm is divisional or matrix in nature, with highly sophisticated control systems.

10. Our structure is centralized with few control systems.

11. In our organization, we have some specialization (accountants and possibly engineers, e.g.) and we are becoming somewhat differentiated.

12. Information processing could best be described as simple, mostly word-of-mouth.

13. Information processing is best described as monitoring performance and facilitating communication between departments.

14. Information processing is sophisticated and necessary for efficient production and earning adequate profits.

15. Information processing is very complex, used for coordination of diverse activities to better serve markets.

16. Information processing is not very sophisticated, but badly needed.

17. Decision-making is centralized at the top of the organization and considered to be not very complex.

18. Most decisions in our firm are made by a group of managers who utilize some systematic analyses, but who are still fairly bold.

19. Most decisions in our firm are made by managers, task forces, and project teams who are trying to facilitate growth through participation.

20. Most decisions in our firm are made by a few managers who take a conservative, internally political approach. 
Anexo B - Questionário original de OLIVEIRA (2009)

\begin{tabular}{|c|c|c|}
\hline Nome do Construto & Variável & Enunciado da questão \\
\hline \multirow{12}{*}{$\begin{array}{l}\text { Previsão e Gestão da } \\
\text { Demanda }\end{array}$} & p16 & Seus sistemas de informação atualmente apóiam os processos de Gerenciamento de Demanda? \\
\hline & p17 & Vocês avaliam a variabilidade da demanda para seus produtos? \\
\hline & $\mathrm{p} 18$ & Vocês têm um processo de previsão de demanda documentado? \\
\hline & p19 & O processo de previsão de demanda utiliza dados históricos para o desenvolvimento das previsões? \\
\hline & p20 & Vocês utilizam métodos matemáticos (estatística) para prever demanda? \\
\hline & $\mathrm{p} 21$ & O processo de previsão de demanda ocorre regularmente? \\
\hline & $\mathrm{p} 22$ & Vocês desenvolvem uma previsão para cada produto? \\
\hline & $\mathrm{p} 25$ & Seu processo de gerenciamento da demanda faz uso de informações oriundas de seus clientes? \\
\hline & p26 & As previsões de demanda são atualizadas semanalmente? \\
\hline & p27 & As previsões de demanda são razoáveis ou confiáveis? \\
\hline & p28 & As previsões de demanda são utilizadas para desenvolver planos e firmar compromissos? \\
\hline & p29 & A precisão das previsões de demanda é medida? \\
\hline \multirow{6}{*}{$\begin{array}{l}\text { Planejamento } \\
\text { Estratégico }\end{array}$} & p1 & O planejamento das estratégias das operações da sua empresa é feito em equipe? \\
\hline & p11 & $\begin{array}{l}\text { A equipe de planejamento das estratégias das operações usa ferramentas de simulação e análise } \\
\text { adequadas para examinar o impacto antes que uma decisão seja tomada? }\end{array}$ \\
\hline & $\mathrm{p} 2$ & A equipe de planejamento das estratégias das operações tem reuniões formais? \\
\hline & $\mathrm{p} 3$ & $\begin{array}{l}\text { As principais funções da cadeia de suprimentos (vendas, marketing, manufatura, logística, etc.) estão } \\
\text { representadas nesta equipe? }\end{array}$ \\
\hline & $\mathrm{p} 4$ & $\begin{array}{l}\text { Vocês têm um processo de planejamento das estratégias das operações documentado (descrição } \\
\text { escrita, gráficos de fluxo, etc.)? }\end{array}$ \\
\hline & $\mathrm{p} 8$ & Quando vocês se reúnem, vocês fazem ajustes na estratégia e os documentam? \\
\hline \multirow{8}{*}{ Orientação Estratégica } & p10 & $\begin{array}{l}\text { A equipe de planejamento das estratégias das operações avalia o impacto de suas estratégias nas } \\
\text { medidas de performance para a cadeia de suprimentos? }\end{array}$ \\
\hline & $\mathrm{p} 9$ & $\begin{array}{l}\text { A equipe de planejamento das estratégias das operações possui medidas de performance para a } \\
\text { cadeia de suprimentos estabelecidas? }\end{array}$ \\
\hline & $\mathrm{p} 12$ & $\begin{array}{l}\text { A equipe de planejamento das estratégias das operações se envolve na seleção de membros para a } \\
\text { equipe de Gerenciamento da Cadeia de Suprimentos? }\end{array}$ \\
\hline & $\mathrm{p} 13$ & A equipe de planejamento das estratégias das operações avalia a lucratividade gerada pelos clientes? \\
\hline & p14 & A equipe de planejamento das estratégias das operações avalia a lucratividade gerada pelos produtos? \\
\hline & $\mathrm{p} 15$ & $\begin{array}{l}\text { A equipe de planejamento das estratégias das operações participa das relações com os clientes e } \\
\text { fornecedores? }\end{array}$ \\
\hline & p6 & A empresa tem as prioridades do cliente definidas? \\
\hline & p7 & A empresa tem as prioridades do produto definidas? \\
\hline \multirow{3}{*}{ Equipe de Compras } & s12 & Vocês possuem uma equipe de compras? \\
\hline & s13 & A equipe de compras se reúne regularmente? \\
\hline & s14 & $\begin{array}{l}\text { Outras áreas (manufatura, vendas, etc.) trabalham em conjunto com os membros da equipe de } \\
\text { compras? }\end{array}$ \\
\hline \multirow{6}{*}{$\begin{array}{l}\text { Relacionamento com } \\
\text { Fornecedores }\end{array}$} & s10 & Vocês planejam de forma colaborativa com seus fornecedores? \\
\hline & s11 & Vocês medem a performance dos fornecedores e dão feedback para eles? \\
\hline & s6 & Seus fornecedores gerenciam seu estoque de suprimentos? \\
\hline & s7 & $\begin{array}{l}\text { Vocês possuem estrutura para o envio de pedidos eletrônicos para seus fornecedores (EDI, e-mail, } \\
\text { Home Page, etc.)? }\end{array}$ \\
\hline & s8 & Vocês compartilham informações sobre planejamento, datas e cronograma com os fornecedores? \\
\hline & s9 & Os fornecedores principais possuem funcionários em suas instalações? \\
\hline
\end{tabular}


CONTIUAÇÃO...

\begin{tabular}{|c|c|c|}
\hline Nome do Construto & Variável & Enunciado da questão \\
\hline \multirow{9}{*}{$\begin{array}{l}\text { Programação da } \\
\text { Produção }\end{array}$} & $\mathrm{m} 1$ & $\begin{array}{l}\text { Vocês possuem um processo de planejamento e programação da produção documentado (descrição } \\
\text { escrita, gráficos de fluxo, etc.)? }\end{array}$ \\
\hline & $\mathrm{m} 10$ & Vocês medem a adequação do plano à produção? \\
\hline & $\mathrm{m} 11$ & $\begin{array}{l}\text { Seus processos de planejamento e programação atuam adequadamente nas necessidades do } \\
\text { negócio? }\end{array}$ \\
\hline & $\mathrm{m} 15$ & Os planos são desenvolvidos no nível de detalhe de cada item? \\
\hline & $\mathrm{m} 2$ & $\begin{array}{l}\text { Seus processos de planejamento e programação da produção são integrados e coordenados ao } \\
\text { longo das divisões? }\end{array}$ \\
\hline & $\mathrm{m} 4$ & Vocês possuem reuniões semanais de planejamento? \\
\hline & $\mathrm{m} 7$ & $\begin{array}{l}\text { Vocês estão utilizando metodologias de planejamento e programação da produção baseadas em } \\
\text { restrições? }\end{array}$ \\
\hline & $\mathrm{m} 8$ & O cronograma da linha de produção é integrado com o processo de agendamento geral? \\
\hline & m9 & Seus sistemas de informação atualmente apóiam os processos de produção? \\
\hline \multirow{9}{*}{$\begin{array}{l}\text { Gestão Integrada da } \\
\text { Rede de Distribuição }\end{array}$} & $\mathrm{d} 18$ & Seus sistemas de informação apóiam o Gerenciamento de Distribuição? \\
\hline & d19 & $\begin{array}{l}\text { As relações internas (particularidades, variabilidades e métricas) na rede de distribuição são } \\
\text { entendidas e documentadas? }\end{array}$ \\
\hline & $\mathrm{d} 21$ & $\begin{array}{l}\text { Os impactos das mudanças no planejamento da distribuição são examinados em detalhe suficiente } \\
\text { antes que as alterações sejam feitas? }\end{array}$ \\
\hline & $\mathrm{d} 24$ & Vocês utilizam alguma ferramenta matemática para auxiliar no planejamento da distribuição? \\
\hline & d26 & $\begin{array}{l}\text { O processo de gerenciamento da distribuição é integrado com outros processos de decisão da } \\
\text { cadeia de suprimentos (planejamento da produção, cronograma, gerenciamento da demanda, etc.)? }\end{array}$ \\
\hline & $\mathrm{d} 27$ & Cada empresa/unidade participante na rede de distribuição possui controles e medidas de estoque? \\
\hline & $\mathrm{d} 28$ & Vocês utilizam re-suprimento automático na rede de distribuição? \\
\hline & d29 & São utilizadas medidas para avaliar o processo de gerenciamento de distribuição? \\
\hline & $\mathrm{d} 30$ & $\begin{array}{l}\text { As medidas de processo de gerenciamento de distribuição são utilizadas para reconhecer e } \\
\text { recompensar seus participantes? }\end{array}$ \\
\hline \multirow{8}{*}{$\begin{array}{l}\text { Flexibilidade de } \\
\text { Pedidos }\end{array}$} & d11 & Vocês mantém a capacidade de responder a pedidos imediatos e não planejados? \\
\hline & d14 & Seus sistemas de informações atualmente apóiam o processo de comprometimento de pedidos? \\
\hline & d15 & Vocês medem situações de falta de estoque? \\
\hline & $\mathrm{d} 25$ & $\begin{array}{l}\text { Um replanejamento rápido pode ser feito para responder aos problemas inesperados e às } \\
\text { mudanças? }\end{array}$ \\
\hline & $\mathrm{d} 4$ & Seus clientes estão satisfeitos com a performance atual dos pedidos entregues a tempo? \\
\hline & d7 & Vocês medem as requisições dos clientes versus entregas? \\
\hline & d8 & $\begin{array}{l}\text { Dado um pedido de um cliente potencial, vocês podem se comprometer, a cada requisição, com } \\
\text { uma quantidade fixa/firme e data de entrega (baseando nas atuais condições)? }\end{array}$ \\
\hline & d9 & Os comprometimentos de entrega projetados geram sentimento de confiança nos clientes? \\
\hline \multirow{6}{*}{ Sponsorship } & d2 & $\begin{array}{l}\text { Tem alguém na direção que apóia o processo de comprometimento de pedidos (um padrinho ou } \\
\text { patrocinador com poder)? }\end{array}$ \\
\hline & $\mathrm{d} 20$ & $\begin{array}{l}\text { Tem alguém na direção que apóia o processo de gerenciamento de distribuição (um padrinho ou } \\
\text { patrocinador com poder)? }\end{array}$ \\
\hline & m3 & $\begin{array}{l}\text { Tem alguém na direção que apóia o processo de planejamento e programação da produção (um } \\
\text { padrinho ou patrocinador com poder)? }\end{array}$ \\
\hline & p5 & $\begin{array}{l}\text { Tem alguém na direção que apóia o processo de planejamento da cadeia de suprimentos (um } \\
\text { padrinho ou patrocinador com poder)? }\end{array}$ \\
\hline & p24 & $\begin{array}{l}\text { Tem alguém na direção que apóia o processo de gerenciamento da demanda (um padrinho ou } \\
\text { patrocinador com poder)? }\end{array}$ \\
\hline & s4 & $\begin{array}{l}\text { Tem alguém na direção que apóia o processo de compras (um padrinho ou patrocinador com } \\
\text { poder)? }\end{array}$ \\
\hline
\end{tabular}


CONTIUAÇÃO...

\section{Nome do Construto Variável}

Enunciado da questão

\begin{tabular}{|c|c|c|}
\hline \multirow{9}{*}{ Estabilidade e Resiliência } & $\mathrm{d} 22$ & As mudanças são feitas sem grande pressão? \\
\hline & $\mathrm{d} 23$ & As entregas são expedidas respeitando o processo normal? \\
\hline & $\mathrm{d} 10$ & Vocês prometem pedidos além do que podem ser satisfeitos pelos atuais níveis de estoque? \\
\hline & d1 & $\begin{array}{l}\text { O processo de comprometimento com pedidos da sua empresa é documentado (descrição escrita, } \\
\text { gráficos de fluxo, etc.)? }\end{array}$ \\
\hline & d17 & $\begin{array}{l}\text { Seu processo de Gerenciamento de Distribuição está documentado (descrição escrita, gráficos de } \\
\text { fluxo, etc.)? }\end{array}$ \\
\hline & s1 & Seu processo de compras é documentado (descrição escrita, gráficos de fluxo, etc.)? \\
\hline & s2 & Seu sistema de informação oferece suporte ao processo de compras? \\
\hline & s3 & As inter-relações com os fornecedores (variabilidades, métricas) são entendidas e documentadas? \\
\hline & s5 & Vocês possuem fornecedores estratégicos para todos os produtos e serviços? \\
\hline \multirow{4}{*}{ Responsividade } & d5 & Vocês atendem a demandas de curto prazo a partir de estoques de produtos acabados? \\
\hline & m5 & $\begin{array}{l}\text { Os tempos de entrega dos fornecedores são as principais considerações no processo de planejamento } \\
\text { e programação? }\end{array}$ \\
\hline & m6 & Os tempos de entrega dos fornecedores são revistos mensalmente? \\
\hline & d3 & Vocês acompanham o percentual de pedidos completos entregues a tempo? \\
\hline \multirow{5}{*}{ Práticas colaborativas } & d13 & $\begin{array}{l}\text { As áreas de vendas, manufatura, distribuição e planejamento colaboram com o processo de } \\
\text { comprometimento de pedidos? }\end{array}$ \\
\hline & p30 & $\begin{array}{l}\text { Os processos de gerenciamento da demanda e os processos de planejamento da produção } \\
\text { (produtos/serviços) estão integrados? }\end{array}$ \\
\hline & $\mathrm{p} 31$ & As áreas de vendas, manufatura e distribuição colaboram no desenvolvimento das previsões? \\
\hline & d16 & $\begin{array}{l}\text { Seu processo de comprometimento de pedidos está integrado com outros processos de decisão na } \\
\text { cadeia de suprimentos? }\end{array}$ \\
\hline & d12 & Vocês reabastecem automaticamente o estoque de algum cliente? \\
\hline \multirow{5}{*}{ Flexibilidade de Produção } & d6 & Vocês fabricam de acordo com pedidos (sob demanda)? \\
\hline & $\mathrm{m} 12$ & $\begin{array}{l}\text { As áreas de vendas, manufatura e distribuição colaboram no processo de planejamento e } \\
\text { programação da produção? }\end{array}$ \\
\hline & $\mathrm{m} 13$ & $\begin{array}{l}\text { As informações referentes à programação dos seus clientes são incluídas no planejamento e } \\
\text { programação da produção da sua empresa? }\end{array}$ \\
\hline & $\mathrm{m} 14$ & $\begin{array}{l}\text { As mudanças no planejamento e programação da produção passam por um processo de aprovação } \\
\text { formal e documentado? }\end{array}$ \\
\hline & p23 & Vocês desenvolvem uma previsão para cada cliente? \\
\hline
\end{tabular}

